\title{
Aliphatic lipids in recent sediments of the Fram Strait/Yermak Plateau (Arctic Ocean): composition, sources and transport processes
}

\author{
Daniel Birgel* ${ }^{*}$, Ruediger Stein, Jens Hefter \\ Alfred Wegener Institute for Polar and Marine Research, Postfach 120161, D-27515 Bremerhaven, Germany
}

Received 17 April 2003; received in revised form 19 February 2004; accepted 19 March 2004

\begin{abstract}
Surface sediments $(n=39)$ from the western Fram Strait and across the Yermak Plateau (Arctic Ocean) were investigated by molecular and isotopic organic geochemical methods to determine the composition, distribution and origin of extractable aliphatic lipids ( $n$-alkanes, $n$-alkanols, fatty acids). Bulk geochemical parameters (TOC-content, $\delta^{13} \mathrm{C}_{\text {org }}$ ) were also determined, including additional samples nearby. Enhanced organic carbon contents of up to $1.6 \%$ along the western slope of the Yermak Plateau and north off Spitsbergen, corroborated by an average $\delta^{13} \mathrm{C}_{\text {org }}$ value of $-22.3 \%$, indicated most of the organic material to be of a marine origin, despite ice-cover. The extractable aliphatic lipids contributed up to $1 \%$ of the sedimentary organic carbon and were dominated by fatty acids $(0.7-9.1 \mathrm{mg} / \mathrm{g}$ TOC), whereas $n$-alkanes and $n$-alkanols contributed only minor amounts (0.1-0.4 mg/g TOC). The detailed molecular and carbon isotopic characterisation of the studied aliphatic compounds enabled assignments of most components to three lipid pools, representing: (a) primary production (marine phytoplankton, seaice algae), (b) secondary inputs (by feeding of zooplankton, benthic organisms and bacteria on the former) and (c) terrestrialderived contributions. The first two compound groups dominated, but varied significantly in relation to the environment and were highest at the MIZ (Marginal Ice Zone), and along the permanently ice-covered western flank of the Yermak Plateau. In contrast, compounds attributable to a terrestrial source were of only minor importance in terms of absolute concentrations and less variable, but showed increasing relative proportions from an average of $8-14 \%$ at and southwards of the MIZ up to $27-$ $33 \%$ on the Yermak Plateau and towards the central Arctic Ocean as a consequence of the weakening signal of primary and secondary production. This study provides further insights into the Arctic Ocean carbon dynamics, but also an example of the impact of ocean-currents on the deposition and composition of organic matter.
\end{abstract}

(C) 2004 Elsevier B.V. All rights reserved.

Keywords: Aliphatic lipids; Biomarker; Phytoplankton; Zooplankton; Transport mechanisms; Sediments; Fram Strait; Yermak Plateau; Arctic Ocean

* Corresponding author. Recent address: Research Center Ocean Margins (RCOM), University of Bremen, Postfach 330 440, D-28334 Bremen, Germany. Tel.: +49-421-218-4602; fax: +49-421-218-8664.

E-mail address: dbirgel@uni-bremen.de (D. Birgel).

\section{Introduction}

The Arctic Ocean and the surrounding areas are considered a low productivity environment due to the presence of an almost perennial sea-ice cover, low 
availability of light, nutrients and suspended matter (Subba Rao and Platt, 1984). The largely closed seaice cover not only has an important influence on the abundance and diversity of marine biota, but also on the oceanic circulation and surface albedo. Despite low annual primary production $\left(1-15 \mathrm{~g} \mathrm{C} \mathrm{m}^{-2}\right.$ year $^{-1}$; English, 1961; Wheeler et al., 1996; Gosselin et al., 1997) for the ice-covered central parts of the Arctic Ocean, increased seasonal phytoplankton and zooplankton productivity at the Marginal Ice Zone (MIZ) and within the Arctic shelf-seas has been reported. Ramseier et al. $(1999,2001)$ proposed a high productivity strip close to the mean annual MIZ, termed the BMIZ (Biological Marginal Ice Zone). Maximum concentrations of nutrients, chlorophyll $a$, high production of phytoplankton in surface waters, as well as maximum fluxes of POC and opal were obtained from sediment traps at various depths (Andreassen et al., 1996; Ramseier et al., 1999; Hebbeln, 2000; Owrid et al., 2000), in conjunction with high vertical export and accumulation rates of organic carbon to the surface sediments (Andreassen et al., 1996; Birgel and Stein, 2003). For the Barents Sea, adjacent to the east of the Yermak Plateau, it was assumed that MIZ-associated production sweeping into the Arctic Ocean results in an annual production of 50-150 $\mathrm{g} \mathrm{C} \mathrm{m}^{-2}$ year $^{-1}$ (Olli et al., 2002 and references therein).

Deep-water exchange between the Arctic and Atlantic Ocean is enabled through the Fram Strait. It is a major driver of global thermohaline circulation, controlling heat transfer and climatically important processes between the Arctic and the world oceans (ARCSS Workshop Steering Committee, 1990; NAD Science Committee, 1992). Up to now knowledge of organic matter composition, in terms of biomarker distributions and concentrations, of recent sediments of the northern Fram Strait has been limited. To improve our understanding of these remote regions, several expeditions were conducted with icebreaking research vessels to the perennially ice-covered Arctic Ocean (Fütterer, 1992, 1994) and northern Fram Strait/Yermak Plateau (Stein and Fahl, 1997; Jokat, 2000; Krause and Schauer, 2001) in the last decade. Organic carbon contents of surface sediments from the Fram Strait and Arctic Ocean areas were investigated earlier (Hebbeln and Berner, 1993; Stein et al., 1994), but biomarker studies previously con- centrated only on selected compounds, e.g. on short$\left(n-\mathrm{C}_{17}, n-\mathrm{C}_{19}\right)$ and long-chain $\left(n-\mathrm{C}_{27}, n-\mathrm{C}_{29}, n-\mathrm{C}_{31}\right) n$ alkanes and short-chain fatty acids $\left(\mathrm{C}_{16: 0}, \mathrm{C}_{16: 1}, \mathrm{C}_{18: 0}\right.$, and $\mathrm{C}_{18: 1}$ ) (Schubert, 1995; Schubert and Stein, 1997). To get more detailed information on the sources and composition of extractable organic matter (EOM) in surface sediments, the molecular and carbon isotopic compositions of aliphatic lipids (fatty acids, $n$-alkanols and $n$-alkanes) in recent sediments of the Fram Strait and on the Yermak Plateau have been investigated. The use of biomarker data as proxies reflecting recent environmental conditions and for palaeoenvironmental reconstruction is a well-established geochemical tool. For sediments from open ocean and deep-sea areas of mid- to low-latitude regions, biomarker compositions mainly reflect primary productivity in the water column, whereas the amounts of freshwater and terrestrial-derived compounds generally are low (e.g. Farrimond et al., 1990; Prahl et al., 1994). In contrast, in sediments of the almost perennial ice-covered Arctic Ocean, organic matter composition might be significantly influenced by a "terrestrial overprint" related to seaice transport processes (Dethleff et al., 2000). The supply of terrigenous organic matter from melting seaice to the seafloor, and by transport within currents is important, as can be seen from previous bulk parameter investigations (e.g. Hebbeln and Berner, 1993; Stein et al., 1994; Schubert and Stein, 1997; Birgel and Stein, 2003). Nonetheless, Wheeler et al. (1996) described a low to moderate primary productivity under permanent sea-ice in the Arctic Ocean, but concluded that it is "less productive than oligotrophic ocean regions not covered by ice". However, from bulk $\delta^{13} \mathrm{C}_{\mathrm{org}}$ and $\delta^{15} \mathrm{~N}_{\text {org }}$ data of ice-covered Arctic marine surface sediments, contributions of marine organic matter up to $50 \%$ were estimated (Schubert and Calvert, 2001) and circumarctic shelf regions and the MIZ are nowadays considered to belong to the most productive environments on earth, particularly during springtime (Wassmann, 2002).

The major goal of this study was to identify and distinguish processes (i.e. primary and secondary production, allochthonous/terrestrial inputs) and the influence of environmental aspects (e.g. ice-cover, current systems) on the deposition of aliphatic lipids in surface sediments of the eastern Fram Strait and on the Yermak Plateau. A first estimation on the compo- 
sition of the organic matter (e.g. the proportions of marine and terrigenous material) was achieved by bulk data analysis (TOC, $\delta^{13} \mathrm{C}_{\mathrm{org}}$ ).

\section{Materials and methods}

\subsection{Study area}

The surface sediment samples studied cover an area from approximately $76^{\circ} \mathrm{N}$ to $82.5^{\circ} \mathrm{N}$ and $5^{\circ} \mathrm{W}$ to $20^{\circ} \mathrm{E}$ between Greenland/Spitsbergen and north of Spitsbergen, known as the Fram Strait and Yermak Plateau (Fig. 1). The study area is influenced by a number of environmental conditions, including permanent or temporary sea-ice cover and a system of oceanic currents, which, amongst other things, impact organic matter composition and distribution. Two major currents, the warm West Spitsbergen Current
(WSC, $\left.T=2-3{ }^{\circ} \mathrm{C} ; S=34.7-34.9\right)$ and the iceinfested East Greenland Current (EGC, $T=-1.5-0$ ${ }^{\circ} \mathrm{C} ; S=30.7-31.0$ ), balance the exchange of Arctic and Atlantic water masses and subdivide Fram Strait in two domains (Schlichtholz and Houssais, 1999a,b; Rudels et al., 2000).

Flowing polewards, the WSC carries warm and saline Atlantic waters along the western coast of Spitsbergen, keeping this region ice-free almost throughout the year (Fig. 1). Here, the WSC is about $100 \mathrm{~km}$ wide and is confined over the continental slope. At about $79^{\circ} \mathrm{N}$, the WSC divides in subbranches. The Return Atlantic Current (RAC) recirculates Atlantic water southward to the eastern edge of the EGC (Gascard et al., 1988; Manley, 1995; Schlichtholz and Houssais, 1999a,b). About 22\% of the northward flowing Atlantic waters have been estimated to become redirected to the south via the RAC (Manley, 1995). The remaining Atlantic water

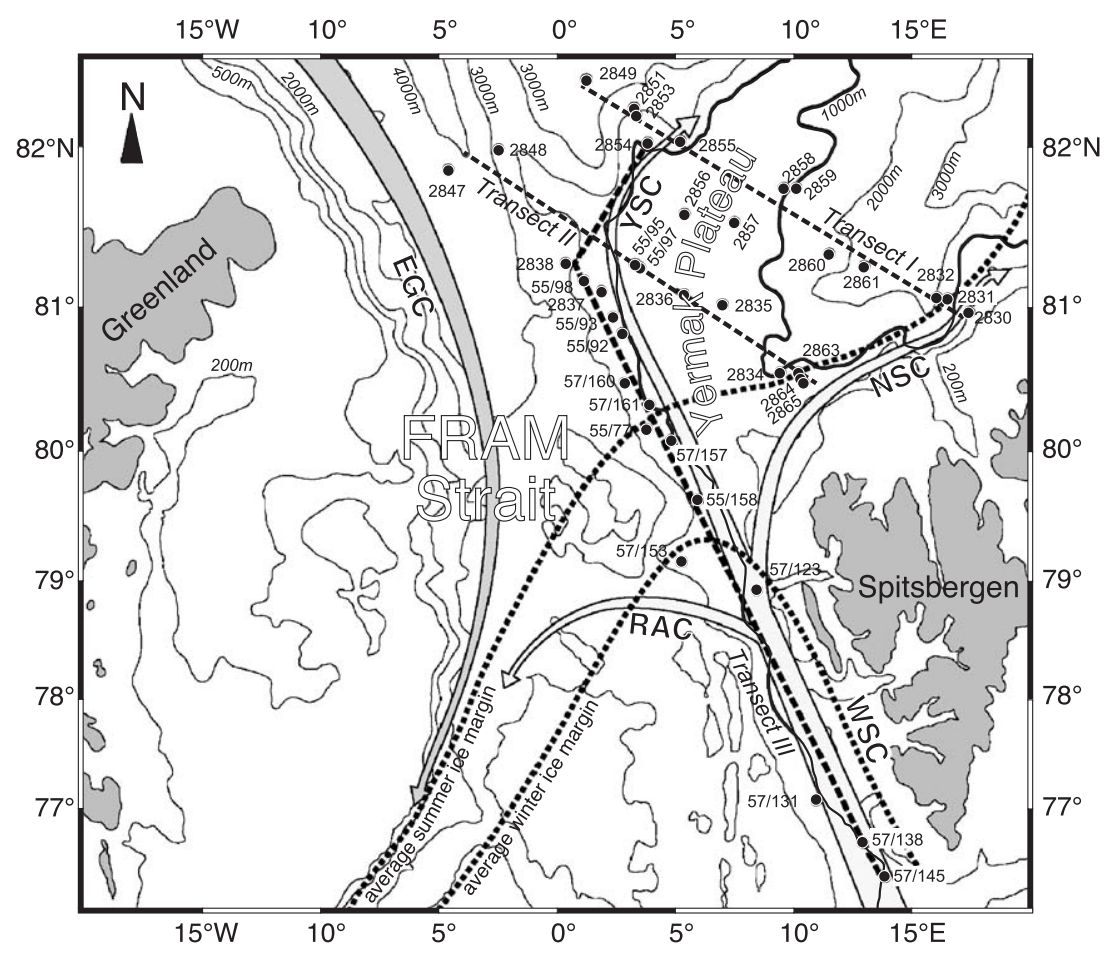

Fig. 1. Map of the study area indicating positions of sampling stations (black dots), locations of Transects I-III, average winter and summer ice margin and major currents. The area of the Yermak Plateau is marked by the bold $1000 \mathrm{~m}$ isobath. The position of the summer ice margin crossing the Transects is derived from satellite and shipboard observations during the sampling periods. Light grey arrows track the inflow of warm, saline Atlantic water $(\mathrm{WSC}=$ West Spitsbergen Current, RAC $=$ Return Atlantic Current, NSC=North Spitsbergen Current, YSC $=$ Yermak Slope Current), dark grey arrow shows the outflow of cold, fresh Arctic water and sea-ice (EGC $=$ East Greenland Current). 
of the WSC then is subdivided into the North Spitsbergen Current (NSC, also referred as Svalbard Branch) and the Yermak Branch at about equal water mass volumes (Manley, 1995). Deflected by coriolisforcing, the NSC (Svalbard Branch) turns east and stays close to the continental shelf north off Spitsbergen, at a depth of approximately $250 \mathrm{~m}$ (Manley, 1995). The Yermak Branch follows the western slope of the Yermak Plateau, but part of it also spreads over the Plateau. Most relevant to our study, an intermediate to deep, bottom-intensified subbranch of the Yermak Branch, named Yermak Slope Current (YSC, Schlichtholz and Houssais, 1999a) has been identified. The YSC, consisting mainly of cold, Norwegian Sea deep-water with low salinity, is topographically forced to follow the western and northern slope of the Yermak Plateau at a water depth of about 1000-1500 m (Fig. 1).

The main outflow of Arctic water masses occurs in the western part of the Fram Strait via the East Greenland Current (EGC). The EGC transports cold, fresh water and sea-ice southwards out of the Arctic (Saloranta and Svendsen, 2001), resulting in a permanent ice-cover throughout the year reaching far to the south.

Current velocities of the WSC were measured west of Svalbard with $9-16 \mathrm{~cm} / \mathrm{s}$ in water depths between 500 and $1500 \mathrm{~m}$ (Fahrbach et al., 2001), whereas YSC velocities are reduced to $1-3 \mathrm{~cm} / \mathrm{s}$ (Schlichtholz and Houssais, 1999a,b). Although no data are available for the NSC, average velocities are supposed to be similar or even lower than those of the YSC.

\subsection{Samples, lipid extraction and analysis}

The surface sediment samples $(0-1 \mathrm{~cm})$ were recovered during the expeditions ARK XIII/2 (Stein and Fahl, 1997), ARK XV/2 (Jokat, 2000) and ARK $\mathrm{XVI} / 1$ and 2 (Krause and Schauer, 2001) on RV Polarstern. The sampling was carried out either with a giant box corer or a multicorer.

All samples were stored at $-30{ }^{\circ} \mathrm{C}$ until further treatment. Sediment samples were freeze-dried, homogenised, and partitioned into subsamples. TOC was determined by means of a LECO CS analyser. Subsamples analysed for total organic carbon isotopic composition $\left(\delta^{13} \mathrm{C}_{\text {org }}\right)$ were acidified with $0.1 \mathrm{~N} \mathrm{HCl}$ prior to measurement and dried at $60{ }^{\circ} \mathrm{C}$ for $12 \mathrm{~h}$. $\delta^{13} \mathrm{C}_{\text {org }}$-measurements were performed in duplicate on an ANCA-SL 20-20 mass spectrometer (Europa Scientific). Subsamples for lipid analysis were extracted and purified by a modified method based on Folch et al. (1957) and Bligh and Dyer (1959). Prior to extraction and fractionation, internal standards were added for quantification of the respective compound class including squalane, nonadecanoic acid methyl ester and cholest-5-en-3 $\beta-o l-D_{6}$. Sediment samples were extracted in three steps using $40 \mathrm{ml}$ each of methanol, methanol:dichloromethane $(1: 1, \mathrm{v} / \mathrm{v})$ and dichloromethane. The combined total extract was transesterified with $1 \mathrm{ml}$ of $5 \%$ concentrated hydrochloric acid in methanol for $12 \mathrm{~h}$ at $50{ }^{\circ} \mathrm{C}$. Silica gel column chromatography was used to separate $n$-alkanes by elution with hexane and a combined FAME (Fatty Acid Methyl Ester) and $n$-alkanol/sterol fraction, eluted with hexane/ethylacetate $(4: 1, \mathrm{v} / \mathrm{v})$, by volume. Sterols $/ n$-alkanols were silylated with 500 $\mu 1$ BSTFA $(N, O$-Bis trimethylsilyltrifluoroacetamide with $1-\%$ trimethyl-chlorosilane) for 2 hours at $60{ }^{\circ} \mathrm{C}$.

All biomarkers were analysed with a Hewlett Packard gas chromatograph (HP 6890) on a 30-m DB5-MS capillary column (J\&W Scientific, $0.25 \mathrm{~mm}$ i.d.; film thickness $0.25 \mu \mathrm{m}$ ), using Helium as carrier gas and a temperature program as follows: $60{ }^{\circ} \mathrm{C}(2$ min), $150{ }^{\circ} \mathrm{C}$ (rate: $15{ }^{\circ} \mathrm{C} / \mathrm{min}$ ), $320{ }^{\circ} \mathrm{C}$ (rate: $3{ }^{\circ} \mathrm{C} /$ $\mathrm{min}), 320{ }^{\circ} \mathrm{C}$ (10 $\mathrm{min}$ isothermal). The injection volume was $1 \mu \mathrm{l}$ (Gerstel Cold Injection System; 60 ${ }^{\circ} \mathrm{C}(10 \mathrm{~s}), 300{ }^{\circ} \mathrm{C}(60 \mathrm{~s})$, rate $\left.12{ }^{\circ} \mathrm{C} / \mathrm{s}\right)$.

Identification of compounds was achieved by GC retention times compared to authentic reference compounds and additionally confirmed by MS fragmentation patterns on a Hewlett Packard 5890 GC/MSD 5972A using identical conditions as described above for GC analysis.

Compound-specific carbon isotope analysis (irmGC/MS) of selected samples was carried out with a HP 6890 GC coupled via a Finnigan GCC-II-interface to a Finnigan Delta ${ }^{\text {plus }}$ XL mass spectrometer. Samples were injected in pulsed-splitless mode and compound separation was achieved on a J\&W DB1-MS capillary column (length $=60 \mathrm{~m}$, i.d. $=0.32 \mathrm{~mm}$, film thickness $=0.25 \mu \mathrm{m}$, carrier gas $=$ helium). The GCtemperature was programmed from $30{ }^{\circ} \mathrm{C}(5 \mathrm{~min})$ to $150{ }^{\circ} \mathrm{C}\left(15^{\circ} / \mathrm{min}\right)$ and then to $320{ }^{\circ} \mathrm{C}(20 \mathrm{~min})$ at a rate of $3{ }^{\circ} \mathrm{C} / \mathrm{min}$. Carbon isotope ratios are notated as $\delta$-values $\left(\delta^{13} \mathrm{C}[\% \circ]\right)$ relative to the PDB-standard and 
have been corrected for the addition of carbon during derivatisation. Several $\mathrm{CO}_{2}$-pulses of known $\delta^{13} \mathrm{C}$ value at the beginning of each run were used for calibration. Reported $\delta^{13} \mathrm{C}$ values were obtained by two to three replicate analyses of each sample to calculate the average carbon isotopic composition. Instrumental precision was checked regularly with standard mixtures of $n$-alkanes $\left(\mathrm{C}_{16}-\mathrm{C}_{30}\right)$, fatty acid methyl esters $\left(\mathrm{C}_{19}, \mathrm{C}_{31}\right)$ and cholesterol- $\mathrm{d}_{6}$, all of known carbon isotopic composition and resulted in standard deviations $<0.4 \%$.

\subsection{Data presentation and subgrouping of samples}

The isolines presented in the distribution map of TOC (Fig. 2) are based on the VG Gridding Algorithm supplied by the ODV-software package (Schlitzer, 2002), allowing construction of a variable resolution, rectangular grid, where grid-spacing along $\mathrm{X}$ and $\mathrm{Y}$ directions varies according to data density.

Based on the organic carbon contents and distribution and the geographical, hydrographical and en- vironmental settings, the samples originating from the eastern part of the Fram Strait and covering the area and surrounding of the Yermak Plateau have been either arranged onto different Transects (I-III, indicated in Fig. 1) or into groups characterising different regions of the investigation area.

The approximately longitudinal Transects I and II are both located $>80^{\circ} \mathrm{N}$ and run across the Yermak Plateau (Fig. 1). Most stations underlie permanent icecover. However, both Transects include eastern stations seasonally influenced by the MIZ and stations with temporary open water conditions. Transect III runs from approximately $76.5^{\circ} \mathrm{N}$ in the south (open water) across the MIZ towards the north (permanently ice-covered) and follows the inflow of Atlantic water from the WSC along the western flank of the Yermak Plateau within the YSC (Fig. 1). Besides our study, oceanographic and biological investigations were recently performed on similar stations or adjacent Transects and stations (Andreassen et al., 1996; Owrid et al., 2000; Soltwedel et al., 2000; Rudels et al., 2000; Rutgers van der Loeff et al., 2002; Schewe and

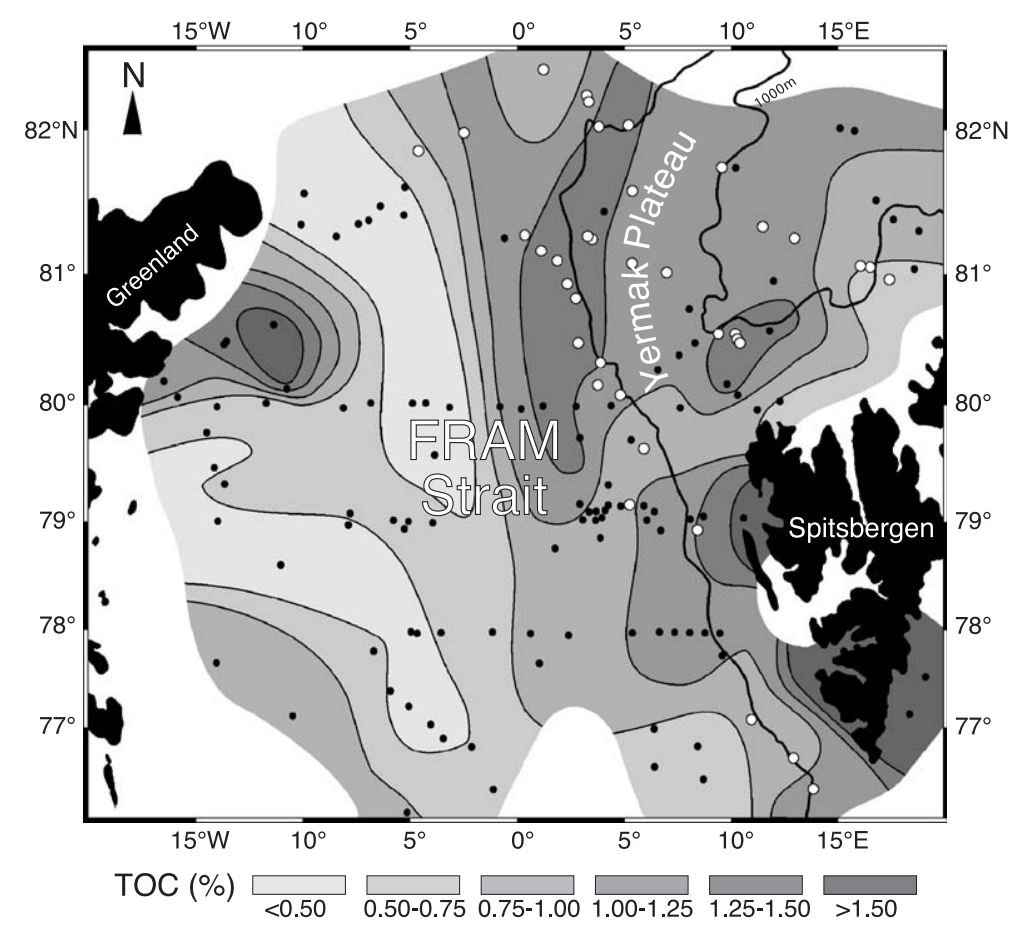

Fig. 2. TOC-content (\%) of surface sediments in the Fram Strait (Hebbeln and Berner, 1993; Stein et al., 1994; Notholt, 1998; Kierdorf, 2001; and on www.pangaea.de). Samples used for lipid analysis are indicated by white dots. The TOC values of these samples can be found in Table 1 . 
Soltwedel, 2003). Despite presenting data of individual stations along the above mentioned Transects, stations have also been arranged in groups representative of the following subareas: Open Water (OW), the Marginal Ice Zone (MIZ), the Yermak Plateau (YP; water depth of about $1000 \mathrm{~m}$ ), the deep (>2000 $\mathrm{m})$ Arctic Ocean (AO) and stations on the western flank of the Yermak Plateau (YSC, Yermak slope current).

\section{Results and discussion}

\subsection{Total organic carbon (TOC) content}

The distribution of total organic carbon (TOC) contents in the Fram Strait is shown in Fig. 2. To improve data density, additional data from stations nearby and from previous studies have been included (Hebbeln and Berner, 1993; Stein et al., 1994; Notholt, 1998; accessible through http://www.pangaea.de; Kierdorf, 2001, Birgel and Stein, 2003). TOC values ranged from $<0.5 \%$ to $>1.5 \%$. In general, TOC-contents divide the Fram Strait along $0^{\circ}$ longitude into two regions, with lower values $(<0.75 \%)$ to the west and higher $(>0.75 \%)$ TOCcontents toward the east. The lower TOC contents in the western part correspond to the permanently icecovered area influenced by the cold and less productive Arctic waters of the EGC. However, a local maximum with TOC-values $>1.25 \%$ appears east of Greenland in an area between ca. $80 / 81^{\circ} \mathrm{N}$ and $10 /$ $15^{\circ} \mathrm{W}$, corresponding to the region of open water (icefree) conditions of the NE Greenland polynya. According to Hebbeln and Berner (1993), this is related to enhanced primary productivity caused by the open water conditions of the polynya, providing light and nutrients that favour phytoplankton growth.

Towards the eastern part of the Fram Strait, surface sediments are generally characterised by higher TOCvalues $(>0.75 \%)$. Towards the shallow western Spitsbergen shelf, TOC-values increase to $>1 \%$. Higher biological productivity, caused by open water conditions and the "warm" surface waters of the WSC seems to be the most reasonable explanation for enhanced TOC-contents on the slope west of Spitsbergen. In addition, an input of terrigenous organic matter across the slope (mainly via gravity-driven, near-bottom downslope transport, Hebbeln and Berner, 1993) towards the deeper central Fram Strait is supplied by the fjords of Spitsbergen, where TOC is $>1.5 \%$. Increased TOC values in the fjord areas might potentially also result from input of reworked organic material (coals) from Spitsbergen (Hebbeln and Berner, 1993). However, Rock-Eval data from samples of this area indicate only minor contributions of coal-derived organic material (Birgel and Stein, 2003 and references therein).

Most interesting, locally enhanced TOC contents $(>1.25 \%)$ are further recorded in the surface sediments situated on the western flank of the Yermak Plateau and north off Spitsbergen. For stations located close to $80^{\circ} \mathrm{N}$, these elevated TOC values can be explained by enhanced seasonal productivity in the vicinity of the ice-edge, where melting processes locally supply nutrients. North of Spitsbergen, productivity might be additionally triggered by relatively warm Atlantic water transported via the NSC resulting in open water areas in summer (e.g. Owrid et al., 2000). However, most of the stations on the western flank of the Yermak Plateau up to approximately $82^{\circ} \mathrm{N}$, where TOC-contents also reach $>1.25 \%$, are ice-covered throughout the year. For these stations, enhanced organic carbon contents cannot be explained by overlying surface water productivity. As described above, this part of the Yermak Plateau is influenced by the Yermak Slope Current (YSC, cf. Fig. 1). Therefore, high TOC-values at these stations might result from the northward transport of organic carbon along the western part of the Yermak Plateau within the YSC. This is in good agreement with recent studies describing resuspension and particle transport occurring especially on the western flank of the Yermak Plateau (Rutgers van der Loeff et al., 2002). Such a transport mechanism from south to north was also proposed by Soltwedel et al. (2000) based on pigment distributions.

\subsection{Concentrations and distribution of compound classes and $\delta^{13} C_{\text {org }}$}

Total concentrations of aliphatic lipids vary by approximately one order of magnitude, from 1149 $\mu \mathrm{g} / \mathrm{g}$ TOC (PS2851) in the northernmost part of the Fram Strait up to $9549 \mu \mathrm{g} / \mathrm{g}$ TOC (PS55/77) in the 
vicinity of the MIZ at $80^{\circ} \mathrm{N}, 5^{\circ} \mathrm{E}$ (Table 1). Total fatty acids clearly dominated the aliphatic lipids, but also showed a high variability from 744 (PS2851) up to $9077 \mu \mathrm{g} / \mathrm{g}$ TOC (PS55/77). Total $n$-alkanes ranged from 167 (PS2865) to $393 \mu \mathrm{g} / \mathrm{g}$ TOC (PS57/131), and comparable concentrations were found for $n$-alkanols
(85-431 $\mu \mathrm{g} / \mathrm{g}$ TOC, PS57/138 and PS55/95, respectively). At all stations, the concentrations of fatty acids exceeded those of $n$-alkanes and $n$-alkanols by factors of $>5-10$.

Despite the large variations observed in the concentrations of the lipid classes, $\delta^{13} \mathrm{C}_{\text {org }}$ values remained

Table 1

Concentrations of aliphatic lipid classes ( $\mu \mathrm{g} / \mathrm{g}$ TOC), $\delta^{13} \mathrm{C}_{\mathrm{ORG}}$ and \%-TOC of surface sediments in northeastern Fram Strait

\begin{tabular}{|c|c|c|c|c|c|c|c|}
\hline \multirow[t]{2}{*}{ Sample } & \multirow[t]{2}{*}{ Transect (subregion ${ }^{\mathrm{a}}$ ) } & $n$-Alkanes ${ }^{\mathrm{b}}$ & $n$-Alkanols ${ }^{\mathrm{b}}$ & Fatty acids $^{\mathrm{b}}$ & Total & \multirow{2}{*}{$\begin{array}{l}\delta^{13} \mathrm{C}_{\mathrm{ORG}} \\
(\% \text { vs. } \mathrm{PDB})\end{array}$} & \multirow[t]{2}{*}{ TOC $(\%)$} \\
\hline & & \multicolumn{4}{|l|}{$\mu \mathrm{g} / \mathrm{g}$ ТOC } & & \\
\hline PS2830 & I & 331 & 268 & 1577 & 2176 & -22.6 & 0.58 \\
\hline PS2831 & I (MIZ) & 266 & 190 & 2781 & 3237 & -22.3 & 0.71 \\
\hline PS2832 & I & 252 & 187 & 1581 & 2020 & -21.9 & 0.78 \\
\hline PS2834 & II (YP) & 262 & 181 & 1356 & 1799 & -21.9 & 1.04 \\
\hline PS2835 & II (YP) & 223 & 207 & 1383 & 1813 & -22.0 & 1.00 \\
\hline PS2836 & II (YP) & 242 & 201 & 1260 & 1703 & -22.2 & 1.00 \\
\hline PS2837 & III (YSC) & 258 & 142 & 1415 & 1815 & -22.4 & 1.51 \\
\hline PS2838 & III & 228 & 151 & 1407 & 1786 & -22.1 & 1.39 \\
\hline PS2847 & II (AO) & 242 & 190 & 1095 & 1527 & -21.9 & 0.75 \\
\hline PS2848 & II (AO) & 265 & 199 & 1379 & 1843 & -22.0 & 1.20 \\
\hline PS2849 & I (AO) & 249 & 226 & 952 & 1427 & -21.5 & 0.67 \\
\hline PS2851 & $\mathrm{I}(\mathrm{AO})$ & 235 & 170 & 744 & 1149 & -22.1 & 1.16 \\
\hline PS2853 & $\mathrm{I}(\mathrm{AO})$ & 218 & 184 & 1162 & 1564 & -22.2 & 0.73 \\
\hline PS2854 & I/III (YSC) & 180 & 313 & 2287 & 2780 & -22.3 & 1.33 \\
\hline PS2855 & I (YP) & 257 & 147 & 1117 & 1521 & -22.0 & 1.27 \\
\hline PS2856 & I (YP) & 265 & 173 & 1255 & 1693 & -21.9 & 1.17 \\
\hline PS2857 & I (YP) & 252 & 227 & 1259 & 1738 & -21.8 & 1.04 \\
\hline PS2858 & I (YP) & 235 & 160 & 1530 & 1925 & -22.5 & 1.23 \\
\hline PS2859 & I (YP) & 246 & 193 & 1247 & 1686 & -22.4 & 1.11 \\
\hline PS2860 & I & 239 & 144 & 1063 & 1446 & -22.0 & 1.22 \\
\hline PS2861 & I & 251 & 191 & 1196 & 1638 & -22.2 & 1.25 \\
\hline PS2863 & II (MIZ) & 267 & 191 & 1490 & 1948 & -22.1 & 1.21 \\
\hline PS2864 & II (MIZ) & 242 & 225 & 2222 & 2689 & -22.1 & 1.42 \\
\hline PS2865 & II & 167 & 122 & 1263 & 1552 & -22.9 & 1.58 \\
\hline PS55/77 & III (MIZ) & 261 & 211 & 9077 & 9549 & -22.4 & 1.32 \\
\hline PS55/92 & III (YSC) & 278 & 172 & 3840 & 4290 & -22.5 & 1.45 \\
\hline PS55/93 & III (YSC) & 289 & 286 & 5231 & 5806 & -22.4 & 1.38 \\
\hline PS55/95 & II (YSC) & 274 & 431 & 3224 & 3929 & -22.3 & 1.38 \\
\hline PS55/97 & II (YP) & 261 & 191 & 1580 & 2032 & -22.3 & 1.25 \\
\hline PS55/98 & III (YSC) & 292 & 182 & 4053 & 4527 & -22.2 & 0.79 \\
\hline PS55/158 & III (OW) & 245 & 120 & 3261 & 3626 & -22.3 & 0.95 \\
\hline PS57/123 & III (OW) & 209 & 97 & 2134 & 2440 & -22.6 & 1.26 \\
\hline PS57/131 & III (OW) & 393 & 131 & 1866 & 2390 & -23.9 & 0.83 \\
\hline PS57/138 & III (OW) & n.d. & 85 & 1530 & 1615 & -23.5 & 0.87 \\
\hline PS57/145 & III (OW) & n.d. & 93 & 1761 & 1854 & n.d. & 1.19 \\
\hline PS57/153 & III (OW) & 223 & 107 & 3327 & 3657 & -22.0 & 1.36 \\
\hline PS57/157 & III (MIZ) & 355 & 195 & 4137 & 4687 & -22.5 & 0.86 \\
\hline PS57/160 & III (YSC) & 266 & 190 & 6630 & 7086 & -22.4 & 1.15 \\
\hline PS57/161 & III (YSC) & 280 & 153 & 3238 & 3671 & -22.4 & 1.39 \\
\hline
\end{tabular}

Bold numbers indicate minimum and maximum values. n.d. $=$ not determined.

${ }^{\mathrm{a}}$ Abbreviations used for subareas: $\mathrm{AO}=\operatorname{Arctic}$ Ocean $\left(>2000 \mathrm{~m}\right.$ water depth, $\left.>81.5^{\circ} \mathrm{N}\right)$; $\mathrm{YP}=$ Yermak Plateau (approx. $1000 \mathrm{~m}$ water depth); $\mathrm{OW}=$ Open water $\left(<80^{\circ} \mathrm{N}\right)$; MIZ $=$ Marginal Ice Zone; YSC $=$ Yermak Slope Current.

${ }^{\mathrm{b}}$ For individual compounds contributing to the respective lipid classes see Appendix A-C. 
relatively constant (average $-22.3 \%$ \pm 0.4 S.D., $n=38$ ) and varied from $-23.9 \%$ (PS 57/131) to $-21.5 \%$ (PS 2849). Only two out of the 38 samples showed a relative ${ }^{13} \mathrm{C}$-depletion corresponding to $\delta^{13} \mathrm{C}_{\text {org }}$-values $<-23 \%$ (Table 1).

Both the carbon isotopic composition and the high abundance of short-chain fatty acids (mainly composed of mono- and polyunsaturated compounds, see below) indicate organic material dominantly derived from a marine source. A marine origin for most of the organic matter, as inferred from the bulk carbon isotope ratios is in accordance with reports from other regions of the Arctic Ocean (e. g. Goñi et al., 2000; Schubert and Calvert, 2001).

The average $\delta^{13} \mathrm{C}_{\text {org }}$ value of $-22.3 \%$ o $( \pm 0.4$ S.D) obtained within our study can be compared to the value of $-21.6 \%$ o $( \pm 0.3)$ representative of Arctic pelagic primary producers determined by Hobson and Welch (1992) and to the range of $\delta^{13} \mathrm{C}_{\mathrm{POC}}$ from -22.0 to $-23.2 \%$ o $(n=3)$ in surface waters of the North East Water Polynya in the western part of the Fram Strait (Notholt, 1998). Compilations of $\delta^{13} \mathrm{C}_{\mathrm{org}}$ values from Arctic Amerasian continental shelf sediments (Goñi et al., 2000; Naidu et al., 2000) and the Siberian Laptev Sea shelf (Mueller-Lupp et al., 2000) showed a general cross-shelf increase in $\delta^{13} \mathrm{C}_{\text {org }}$ due to seawards increasing contributions of marine organic carbon. Depending on the shelf area, values of $-24 \%$ o to $-21 \%$ o were attributed to represent the marine organic carbon source, whereas the terrestrial organic carbon showed a rather uniform $\delta^{13} \mathrm{C}_{\text {org }}$-value of approximately $-27 \%$. For comparison, $\delta^{13} \mathrm{C}_{\text {org }}{ }^{-}$ ratios from typical modern Arctic tundra vegetation range from $-27.2 \%$ to $-29.2 \%$ (Pfeiffer and Janssen, 1993; Gundelwein, 1998).

The different characteristics for the subareas defined with respect to the occurrence of aliphatic lipids are most obvious from the averaged concentrations given in Table 2. Lowest average amounts of total aliphatic lipids were present in those regions covered permanently by ice, i.e. in surface sediments north of the Yermak Plateau towards the deeper $(>2000 \mathrm{~m})$ Central Arctic Ocean (AO, $1502 \mu \mathrm{g} / \mathrm{g}$ TOC, Table 2) and on the shallower $(<1000 \mathrm{~m})$ Yermak Plateau itself (YP, $1768 \mu \mathrm{g} / \mathrm{g}$ TOC, Table 2). Total fatty acid concentrations averaged $1066 \mu \mathrm{g} / \mathrm{g}$ TOC for the AO and $1332 \mu \mathrm{g} / \mathrm{g}$ TOC on the YP. As mentioned, both regions are characterised by permanent ice-cover,

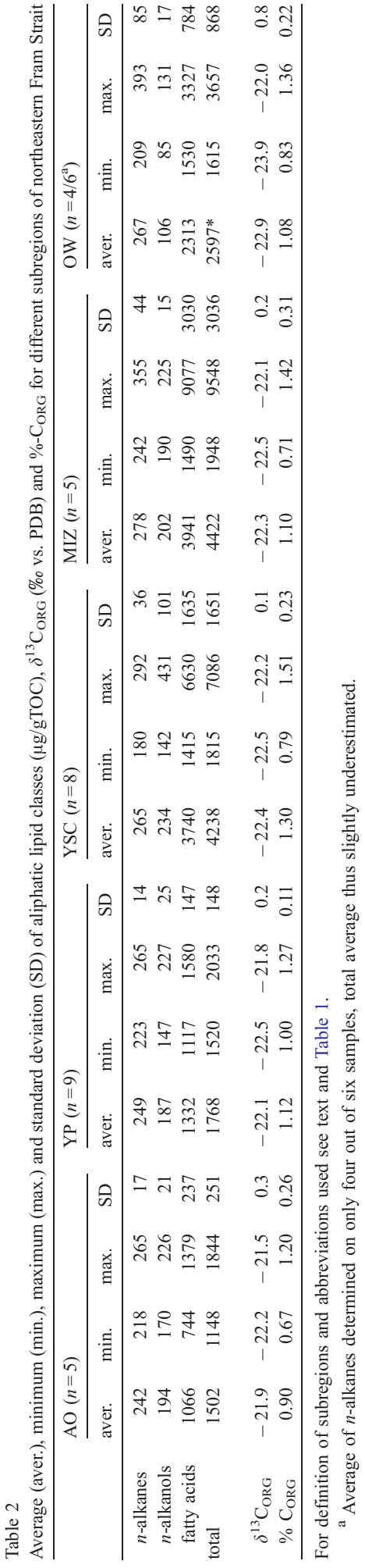


increasing in thickness to the north. Thus, the somewhat reduced total fatty acid concentrations towards the north in the AO compared to the YP might reflect an influence of the thickness of the ice-cover on the amounts of fatty acids produced and deposited in the sediments. Maximum average concentrations of total aliphatics (4422 $\mu \mathrm{g} / \mathrm{g}$ TOC) and total fatty acids (3941 $\mu \mathrm{g} / \mathrm{g}$ TOC) were observed for stations situated under or in the vicinity of the MIZ (Table 2), supposed to represent the zone of highest seasonal primary productivity. Despite maximum average amounts, total fatty acid concentrations of surface sediments close to the MIZ are also characterised by substantial variability, as expressed by the wide range (1490-9077 $\mu \mathrm{g} / \mathrm{g}$ TOC, Table 2) and large standard deviation $(\mathrm{SD}=$ $3030 \mu \mathrm{g} / \mathrm{g}$ TOC, Table 2). Both, maximum concentration and variation thus might reflect the highly dynamic and productive environmental conditions of the MIZ.

In the open water (OW) areas south of the MIZ, total aliphatic lipids averaged $2597 \mu \mathrm{g} / \mathrm{g}$ TOC and total fatty acids $2313 \mu \mathrm{g} / \mathrm{g}$ TOC, which is lower than at the MIZ but higher than compared to the icecovered AO and YP. For the YSC region, even though also situated under permanent ice-coverage, concentration levels of aliphatic lipids were found to be surprisingly high (total: $4238 \mu \mathrm{g} / \mathrm{g}$ TOC, fatty acids: $3740 \mu \mathrm{g} / \mathrm{g}$ TOC, Table 2) and better compare to those at the MIZ rather than to the low amounts observed for the YP and AO.

It is noteworthy that the averaged total fatty acid concentrations (and consequently also the sum of total aliphatics) showed a marked difference with respect to the environmental regimes, whereas the average total amounts of $n$-alkanes and $n$-alkanols did not show major variations. This indicates that the fatty acids mostly derive and reflect local environmental conditions and autochthonous sources, whereas $n$-alkanes and $n$-alkanols most probably are allochthonous.

\subsection{Composition and sources of selected aliphatic lipids}

\subsubsection{Fatty acids}

An overview on the composition of the fatty acids identified in the samples is provided in the following section. Their potential sources are discussed paying special emphasis to the uniqueness of the Arctic environment. Abbreviations used for unsaturated fatty acids (e. $\mathrm{g} \mathrm{C}_{16: 1 n-7}$ ) designate the location of the (first, in case of PUFA) double bond with reference to the end of the chain (opposite to the carboxyl group), following the recommendation of the IUPAC-IUB Commission on Biochemical Nomenclature recommendation (1976). The compositions of the fatty acid fraction for all stations are given in Appendix A and average values for the different subregions are presented in Table 3.

The fatty acids consisted of branched (iso-/anteiso- $\mathrm{C}_{15}$ and $\mathrm{C}_{17}$ ), n-saturated, monounsaturated (MUFA) and polyunsaturated (PUFA) compounds. In all samples, even numbered fatty acids (especially those with 14, 16 and 18 carbon atoms) showed a strong predominance. Relative proportions of saturated fatty acids $\left(\mathrm{C}_{14}-\mathrm{C}_{28}\right)$ ranged from $25 \%$ at the MIZ (station PS55/77) up to $56 \%$ in the northern, ice-covered part of the Fram Strait (station PS2851). Contributions of MUFA ranged from 29\% (PS2851) to $59 \%$ (PS55/95) and up to 22\% (PS55/77) of the fatty acid fraction consisted of PUFA (Appendix A). Most of the variation in fatty acid concentrations is already explained when looking at the amounts of saturated fatty acids and MUFA, and as both were the principle fatty acid subfractions, their proportions covaried and showed a significant negative correlation $(r=-0.929)$.

Branched fatty acids showed less variability and were of minor relative and absolute abundance. Overall, they contributed only $2-9 \%$ to the total fatty acids, whereby on average this proportion was lower at MIZ-stations (4\%) than for AO- and YP-samples (8\%) (Table 3). The short-chain $\mathrm{C}_{16}$ and $\mathrm{C}_{18}$ fatty acids were most abundant throughout all samples, with (a) a general predominance of the respective monounsaturated compounds (i.e. the ratios 16:1/16:0 and 18:1/18:0 being >1, Appendix A) and (b) a higher abundance of $\mathrm{C}_{16}$ than $\mathrm{C}_{18}$ structures. Compared to $\mathrm{C}_{16}$ and $\mathrm{C}_{18}$ MUFA, $\mathrm{C}_{20: 1}$ and $\mathrm{C}_{22: 1}$ were present at lower levels. $\mathrm{C}_{20: 4}$ and $\mathrm{C}_{20: 5}$ clearly dominated the PUFA-fraction, and were often found at higher amounts than $\mathrm{C}_{18: 1}$ and the long-chain saturates (>n$\mathrm{C}_{22}$ ). When comparing the amounts of individual fatty acids among all stations, significant differences in the extent of the respective concentration ranges (i.e. the ratio of maximum/minimum concentrations) became obvious, depending on the fatty acid type. As a 
Table 3

Average concentrations ( $\mu \mathrm{g} / \mathrm{g}$ TOC) of fatty acids, percentual composition and ratios in surface sediments for subregions of northeastern Fram Strait

\begin{tabular}{|c|c|c|c|c|c|c|c|c|c|c|c|}
\hline \multirow[t]{2}{*}{ Compound } & \multirow{2}{*}{$\begin{array}{l}\text { Assigned } \\
\text { lipid pool }\end{array}$} & \multicolumn{2}{|c|}{$\mathrm{AO}(n=5)$} & \multicolumn{2}{|c|}{$\mathrm{YP}(n=9)$} & \multicolumn{2}{|c|}{$\mathrm{YSC}(n=8)$} & \multicolumn{2}{|c|}{$\operatorname{MIZ}(n=5)$} & \multicolumn{2}{|c|}{ OW $(n=6)$} \\
\hline & & Aver. & $\mathrm{SD}$ & Aver. & $\mathrm{SD}$ & Aver. & SD & Aver. & $\mathrm{SD}$ & Aver. & $\mathrm{SD}$ \\
\hline \multicolumn{12}{|l|}{ n-Saturates } \\
\hline 14 & A & 47 & 12 & 51 & 7 & 183 & 94 & 221 & 215 & 111 & 58 \\
\hline 15 & B & 13 & 3 & 15 & 2 & 30 & 12 & 28 & 14 & 23 & 5 \\
\hline 16 & & 167 & 38 & 197 & 27 & 553 & 303 & 605 & 441 & 361 & 150 \\
\hline 17 & B & 7 & 2 & 8 & 2 & 17 & 8 & 18 & 10 & 15 & 7 \\
\hline 18 & & 42 & 5 & 39 & 4 & 65 & 24 & 61 & 14 & 49 & 11 \\
\hline 20 & & 23 & 4 & 20 & 5 & 26 & 10 & 26 & 5 & 20 & 10 \\
\hline 21 & & 6 & 1 & 6 & 1 & 7 & 2 & 7 & 2 & 4 & 1 \\
\hline 22 & & 31 & 5 & 31 & 5 & 34 & 9 & 29 & 3 & 18 & 5 \\
\hline 23 & & 9 & 3 & 12 & 1 & 15 & 5 & 10 & 1 & 6 & 2 \\
\hline 24 & $\mathrm{~A}+\mathrm{C}$ & 60 & 5 & 65 & 8 & 77 & 20 & 66 & 9 & 43 & 11 \\
\hline 25 & & 14 & 3 & 16 & 4 & 17 & 5 & 16 & 3 & 9 & 3 \\
\hline 26 & $\mathrm{~A}+\mathrm{C}$ & 61 & 5 & 60 & 8 & 73 & 18 & 62 & 5 & 41 & 14 \\
\hline 27 & & 15 & 2 & 14 & 2 & 32 & 27 & 18 & 6 & 14 & 7 \\
\hline 28 & $\mathrm{~A}+\mathrm{C}$ & 45 & 16 & 38 & 9 & 46 & 32 & 27 & 25 & 18 & 23 \\
\hline \multicolumn{12}{|l|}{ Monounsaturates } \\
\hline $16: 1 n-7$ & A & 170 & 64 & 256 & 45 & 1058 & 545 & 1257 & 1372 & 657 & 404 \\
\hline $16: 1 n-5$ & A & 31 & 6 & 56 & 43 & 228 & 313 & 81 & 40 & 128 & 98 \\
\hline $18: 1 n-9$ & B & 48 & 16 & 70 & 15 & 312 & 315 & 181 & 62 & 104 & 34 \\
\hline $18: 1 n-7$ & B & 80 & 38 & 111 & 19 & 181 & 121 & 285 & 231 & 194 & 120 \\
\hline $20: 1 n-9$ & B & 11 & 10 & 15 & 7 & 22 & 11 & 27 & 14 & 15 & 2 \\
\hline $20: 1 n-7$ & B & 6 & 4 & 7 & 5 & 39 & 25 & 25 & 18 & 34 & 14 \\
\hline $22: 1 n-11,22: 1 n-9^{\mathrm{a}}$ & B & 25 & 9 & 31 & 7 & 48 & 23 & 42 & 28 & 18 & 12 \\
\hline
\end{tabular}

Polyunsaturates

\begin{tabular}{|c|c|c|c|c|c|c|c|c|c|c|c|}
\hline $18: 2$ & & 11 & 6 & 25 & 13 & 68 & 45 & 69 & 42 & 47 & 30 \\
\hline $18: 4 n-3$ & A & 28 & 11 & 21 & 9 & 50 & 27 & 81 & 86 & 37 & 19 \\
\hline $20: 2$ & & 7 & 4 & 7 & 4 & 24 & 31 & 27 & 21 & 21 & 12 \\
\hline $20: 4 n-6$ & A & 9 & 7 & 21 & 13 & 110 & 92 & 224 & 323 & 69 & 36 \\
\hline $20: 5 n-3$ & A & 9 & 6 & 23 & 16 & 230 & 169 & 280 & 284 & 128 & 85 \\
\hline $20: 4 n-3$ & A & 5 & 3 & 5 & 3 & 12 & 14 & 18 & 26 & 5 & 9 \\
\hline $22: 6 n-3$ & A & 4 & 1 & 6 & 3 & 9 & 3 & 11 & 4 & 10 & 4 \\
\hline \multicolumn{12}{|l|}{ Branched } \\
\hline i-15 & B & 29 & 9 & 39 & 4 & 58 & 12 & 49 & 7 & 39 & 8 \\
\hline ai-15 & B & 39 & 13 & 47 & 4 & 70 & 19 & 58 & 9 & 47 & 13 \\
\hline i-17 & B & 7 & 2 & 9 & 1 & 28 & 30 & 18 & 4 & 16 & 4 \\
\hline ai-17 & B & 8 & 1 & 10 & 1 & 21 & 20 & 15 & 3 & 15 & 5 \\
\hline Total ( $\mu \mathrm{g} / \mathrm{g}$ TOC) & & 1066 & 237 & 1332 & 147 & 3740 & 1635 & 3941 & 3030 & 2313 & 784 \\
\hline$\%$ Assigned & & 70 & 3 & 72 & 2 & 78 & 4 & 78 & 5 & 76 & 3 \\
\hline$\%$ Saturated & & 51 & 5 & 43 & 3 & 31 & 6 & 30 & 7 & 32 & 2 \\
\hline$\%$ MUFA & & 35 & 4 & 41 & 4 & 50 & 6 & 48 & 7 & 50 & 1 \\
\hline$\%$ PUFA & & 7 & 1 & 8 & 2 & 13 & 4 & 18 & 4 & 14 & 2 \\
\hline$\%$ Branched & & 8 & 1 & 8 & 1 & 5 & 2 & 4 & 2 & 5 & 1 \\
\hline \multicolumn{12}{|l|}{ Ratios } \\
\hline $16: 1 / 16: 0$ & & 1.2 & 0.2 & 1.6 & 0.5 & 2.3 & 0.8 & 2.2 & 0.6 & 2.2 & 0.3 \\
\hline $18: 1 / 18: 0$ & & 3.0 & 1.0 & 4.7 & 0.8 & 7.6 & 2.4 & 7.7 & 3.8 & 6.1 & 1.6 \\
\hline
\end{tabular}


general rule, this variability increased in magnitude from even numbered LCFA $\sim$ branched $<$ saturates $<$ MUFA $<$ PUFA. Thus, the concentrations of branched and even numbered LCFA varied only by a factor of about 5-10, whereas those of the MUFA and PUFA varied by factors of up to $\sim 60$ and $\sim 270$, respectively. In terms of absolute amounts, the concentrations of the two major $\mathrm{C}_{16}$-fatty acids varied from 119 to $1353 \mu \mathrm{g} / \mathrm{g}$ TOC $\left(\mathrm{C}_{16: 0}\right)$ and 97 to $3612 \mu \mathrm{g} / \mathrm{g}$ TOC $\left(\mathrm{C}_{16: 1 n-7}\right)$, respectively. The highest variability was observed for $\mathrm{C}_{20: 5 n-3}$, ranging over two orders of magnitude from 3 up to $773 \mu \mathrm{g} / \mathrm{g}$ TOC (Appendix A).

Though averaging smoothes much of this variability, clear differences in the fatty acid compositions remained obvious when comparing the different subregions of the study area (Table 3). On average, stations positioned close to or at the MIZ contained highest total fatty acid amounts (3941 $\mu \mathrm{g} / \mathrm{g}$ TOC), the highest fraction of PUFA (18\%) and the lowest proportions of saturated (30\%) and branched (4\%) compounds. This situation is reversed for surface sediments deposited under permanent ice-cover, (with the exception of YSC-stations, see below) where saturated $(51 \%$ and $43 \%)$ and branched fatty acids $(8 \%)$ are of greater relative importance, while PUFA (7-8\%) but also total fatty acid concentrations are lowest $(1066 \mu \mathrm{g} / \mathrm{g}$ TOC, AO and $1332 \mu \mathrm{g} / \mathrm{g}$ TOC, YP).

Surface sediments from the area of open water conditions (OW) compare in fatty acid distribution to those of the MIZ, but comprise only about half the amount (OW: $2313 \mu \mathrm{g} / \mathrm{g}$ TOC, MIZ: $3941 \mu \mathrm{g} / \mathrm{g}$ TOC). Though under comparable permanent ice-cover to the AO- and YP-stations, surface sediments on the western Yermak slope (YSC, Table 3) contained fatty acids similar in concentration and distribution as stations at the MIZ.

The marginal ice zones (MIZ) in the Fram Strait are known to provide favourable environmental conditions for enhanced seasonal productivity and indeed, most of the major fatty acids described above can reliably be attributed to primary production. The dominant fatty acid within these samples, $\mathrm{C}_{16: 1 n-7}$, is a common lipid-constituent in microalgae of diverse taxa, such as diatoms, dinoflagellates, prymnesiophytes and haptophytes. $\mathrm{C}_{16: 1 n-7}$ accounts for $>30 \%$ to the fatty acids of diatoms whilst other algae, e.g. green algae, contain lower or trace levels of this component (Volkman et al., 1989; Viso and Marty, 1993).

Other fatty acids, such as $\mathrm{C}_{14: 0}, \mathrm{C}_{16: 0}, \mathrm{C}_{18: 1 n-9}$, $\mathrm{C}_{20: 1 n-9}, \mathrm{C}_{20: 5 n-3}$, and $\mathrm{C}_{22: 6 n-3}$ are frequently encountered in the aquatic environment. Being common constituents of the lipid fraction from diverse phytoplankton species (Volkman et al., 1989; Viso and Marty, 1993; Pond et al., 1998; Volkman et al., 1998), their occurrence in water, particulate and sediment samples is therefore usually related to surface water productivity, although neither restricted to a marine nor to an exclusive phytoplankton origin (as discussed below for zooplankton contributions). In estuaries, shelf regions and marginal seas, (i.e. areas influenced by riverine inputs) these compounds, if derived from plankton, more likely result from contributions of freshwater/lacustrine species. For the Arctic, this has been shown e.g. for the Siberian Laptev Sea (Fahl and Stein, 1999). In addition, in polar regions sea-ice algae (living in the ice, meltwater-ponds on the ice, in the water column close to the underside of the ice, or close to the ice-edge) provide another plausible source for the above-mentioned fatty acids. Several studies (e.g. Henderson et al., 1998; Falk-Petersen et al., 1998) have investigated the fatty acid distributions of icealgal assemblages and phytoplankton from the MIZ in the Barents Sea, adjacent to the east of our investigation area. From these studies it is known that the ice-algal assemblages found under the ice and close to the MIZ are dominated by diatoms such as Nitzschia frigida and Melosira arctica, consistent

Notes to Table 3:

$\mathrm{SD}=$ standard deviation. $n=$ number of samples included. \% Assigned=total fraction of fatty acids assigned to distinct sources. MUFA = monounsaturated fatty acids. PUFA= polyunsaturated fatty acids. For definition of subregions and abbreviations (AO, YP, YSC, MIZ, OW) see text and Table 1. Letters A, B, C indicate assignment of fatty acids to the lipid pools explained in Section 4.3. Notice that the amounts of long chain $n$-saturates represent a mixture of lipid pools $\mathrm{A}$ and $\mathrm{C}$, as revealed by their stable carbon isotopic composition (see Section 3.3.3). Individual fatty acid amounts contributing to the averages are provided in Appendix A.

${ }^{\text {a }}$ Sum of both isomers. 
with the universal predominance of diatoms in assemblages of sea-ice algae (e.g. Kirst and Wiencke, 1995). The fatty acids of the mentioned sea-ice diatoms also consist mainly of $\mathrm{C}_{14: 0}, \mathrm{C}_{16: 0}$, $\mathrm{C}_{16: 1 n-7}$ and $\mathrm{C}_{20: 5 n-3}$, similar to diatoms from temperate environments (Volkman et al., 1989; Viso and Marty, 1993).

The ratio of $\Sigma C_{16: 1} / C_{16: 0}$ as a general diatom indicator was proposed by Claustre et al. (198889 ) and values $>1.6$ have been used as evidence for diatom-derived fatty acid contributions in diverse aquatic systems, including the cold environment (Budge and Parrish, 1998; Parrish et al., 2000; Budge et al., 2001; Ramos et al., 2003). This is supported by comparisons of $\mathrm{C}_{16: 1} / \mathrm{C}_{16: 0}$ ratios among different taxonomic classes of marine microalgae (Viso and Marty, 1993; Zhukova and Aizdaicher, 1995). According to the fatty acid distributions provided by Falk-Petersen et al. (1998) and Henderson et al. (1998) $\sum \mathrm{C}_{16: 1} / \mathrm{C}_{16: 0^{-}}$ ratios range from 1 to 2.5 for $N$. frigida and $M$. arctica associations from the MIZ in the Barents Sea. However, it should be noted that this ratio (a) also varies with growth rate (e.g. Mayzaud et al., 1989), and (b) can also significantly decrease during sedimentation of living phytoplankton due to the higher susceptibility of unsaturated fatty acids to the biological and/or chemical degradation (e.g. Tanoue and Handa, 1980 and references therein). Thus, the ratio of $\mathrm{C}_{16: 1} / \mathrm{C}_{16: 0}$ in surface sediments is rarely $>1$ and more typically well below 1 . Given the values from Belicka et al. (2002), surface sediments of various Arctic Ocean basins have $\mathrm{C}_{16: 1} / \mathrm{C}_{16: 0}$ ratios from 0.1 to 0.7 , whereas in surface sediments and particles collected on the Chukchi Shelf this ratio varies from 1.1-2.1. Constrained by these complementary data, we argue that these higher ratios are related to diatom-dominated phytoplankton blooms.

Among our samples, this ratio ranged from 1.0 to 3.8 (Appendix A). Throughout our samples this ratio is surprisingly high. However, it was markedly lower in Arctic Ocean and Yermak Plateau samples under permanent ice-cover (AO, YP: average 1.2-1.6, Table 3 ) compared to stations derived from the MIZ, OW, or the YSC (average 2.2-2.3, Table 3).

Diatoms are known to be a primary source of PUFA such as $\mathrm{C}_{18: 4 n-3}, \mathrm{C}_{20: 5 n-3}$, and $\mathrm{C}_{20: 4 n-3}$ (Volk- man et al., 1989; Zhukova and Aizdaicher, 1995). In major, we suggest that diatoms also account for the sedimentary occurrence of PUFA in the eastern Fram Strait and on the Yermak Plateau (Appendix A), whereby $\mathrm{C}_{20: 5 n-3}$ is usually the most prominent single PUFA. As could be seen for the variations in the $\mathrm{C}_{16: 1} / \mathrm{C}_{16: 0}$ ratios, the contribution of PUFA to the total fatty acids is relatively high at the MIZ$(18 \%)$, intermediate at YSC- and OW-stations (13$14 \%)$ and lower on the YP and in the AO (7-8\%, Table 3). For all samples $(n=39)$, there is a highly significant correlation of the amounts of $\mathrm{C}_{16: 1 n-7}$ and $\mathrm{C}_{18: 4 n-3}(r=0.911), \mathrm{C}_{20: 5 n-3}(r=0.915)$ and $\mathrm{C}_{20: 4 n-3}$ $(r=0.908)$, respectively. Together, therefore, these results indicate that significant proportions of the fatty acids derive from diatom-dominated phytoplankton and ice-algae. This organic matter is delivered to the sediment surface in a good state of preservation, as indicated by the resemblance of the major fatty acid distribution not only to that published for cultured diatoms, but also to nearby upper water column diatom samples. Compared to surface sediments from the central Arctic Ocean (AO) and on the Yermak Plateau (YP), a higher proportion of this relatively fresh and undegraded material is especially well preserved in the sediments originating from the area of the MIZ, but also from the YSC. This is further confirmed by comparable variations in relative proportions of intact chlorophyll- $a$ to the total sedimentary chloroplast pigments, an independent indicator of the "freshness" of primary organic matter at the seafloor, as reported by Soltwedel et al. (2000) for the same samples.

Common to organisms of all taxa, saturated $\mathrm{C}_{14}$, $\mathrm{C}_{16}$, and $\mathrm{C}_{18}$ fatty acids are less source-specific than mono- and polyunsaturated fatty acids. Their ubiquity and their probable additional derivation from (bio-) geochemical reduction of unsaturated fatty acids generally limit their biomarker potential in marine geochemical investigations, especially in deeper sediments. As stated above, the $\mathrm{C}_{16}$ saturated fatty acid was consistently present in lower abundance than the corresponding MUFA, and this is even more obvious for the $\mathrm{C}_{18: 1} / \mathrm{C}_{18: 0}$-ratios (1.912.6, Appendix A). Both ratios are unique of a mixed fresh phyto-/zooplankton source rather than a geochemical degradation product for $\mathrm{C}_{16: 0}$ and 
$\mathrm{C}_{18: 0}$ seems most likely. However, we infer that the saturated $n$-fatty acid $\mathrm{C}_{14: 0}$ is reliably derived from primary production, consistent with a high general abundance of this compound within diatoms (Volkman et al., 1989; Viso and Marty, 1993), Arctic ice algae and phytoplankton from the MIZ (FalkPetersen et al., 1998). It is noteworthy that the concentrations of $\mathrm{C}_{14: 0}$ in our samples are even more strongly correlated $(r=0.992)$ to those of $\mathrm{C}_{16: 1 n-7}$ than the various PUFA and $\mathrm{C}_{16: 1 n-7}$.

Arctic and Antarctic zooplankton (copepods) and a variety of Arctic benthic organisms contain significant levels of $\mathrm{C}_{18: 1}$ as well, at comparable or even higher contents than $\mathrm{C}_{16: 1}$ (Albers et al., 1996; Graeve et al., 1997). $\mathrm{C}_{18: 1 n-7}$ is a known chain elongation product from dietary uptake of a $\mathrm{C}_{16: 1 n-7}$ fatty acid (Sargent and Henderson, 1986). A similar synthetic pathway has been proposed for benthic organisms collected on the shelves off northeast Greenland, Spitsbergen and the western Barents Sea (Graeve et al., 1997). A chain elongation pathway of $\mathrm{C}_{18: 1 n-9}$ to $\mathrm{C}_{22: 1 n-11}$ via the intermediate $\mathrm{C}_{20: 1 n-9}$ is known for copepods of both Polar Oceans (Kattner and Hagen, 1995). As an energetic adaptation to the cold, copepods from high-latitudes are known for their extensive accumulation of waxesters $(>70 \%$ of total lipids) as storage lipids, and these waxes are dominated by fatty acids such as $\mathrm{C}_{20: 1 n-9}$ and $\mathrm{C}_{22: 1 n-11}$, as well as $\mathrm{C}_{18: 1}$ (Kattner and Hagen, 1995; Albers et al., 1996; Graeve et al., 1997). These typical fatty acid constituents of waxesters are also known from copepods of the Fram Strait (Kattner et al., 1989), at the MIZ, and from open waters of Spitsbergen (Scott et al., 2001). PUFA such as $\mathrm{C}_{20: 5 n-3}$ and $\mathrm{C}_{20: 4 n-6}$ are essential fatty acids for most of the higher marine organisms, including zooplankton. Their variable amounts within Arctic copepods and various benthic organisms are considered to reflect different feeding behaviours (Graeve et al., 1997; Scott et al., 2002).

A variety of organisms other than zooplankton are known to have the capacity to synthesise $\mathrm{C}_{18}$ monounsaturated fatty acids. $\mathrm{C}_{18: 1 n-7}$ has been considered to be a bacteria-specific fatty acid marker (Parkes and Taylor, 1983; Gillan and Sandstrom, 1985), but a compilation of fatty acid compositions of some representative marine bacteria (Russel and Nichols, 1999) shows $\mathrm{C}_{18: 1 n-7}$ only to account for $1-3.6$ wt. $\%$ of total fatty acids. The odd-numbered $n$-fatty acids with 15 and 17 carbon atoms as well as their isoand anteiso-homologues identified in the samples investigated also point towards a bacterial origin (Leo and Parker, 1966; Cooper and Blumer, 1968; Boon et al., 1979; Perry et al., 1979; Sicre et al., 1988; Kaneda, 1991). Compared to the higher relative abundances of $n$-, $i$ - and $a i-\mathrm{C}_{15}$ and $\mathrm{C}_{17}$ acids (8.4$17.5 \%$ ) given for marine bacteria by Russel and Nichols (1999), $\mathrm{C}_{18: 1 n-7}(1-3.6 \%)$ is of only minor importance. Conversly, the higher amounts of $\mathrm{C}_{18: 1 n-7}$ compared to $n-, i$-, and ai- $\mathrm{C}_{15}$ and $\mathrm{C}_{17}$ fatty acids within our samples (cf. Appendix A; Table 3) point towards a source of $\mathrm{C}_{18: 1 n-7}$ other than bacteria, most likely zooplankton.

Long-chain saturated fatty acids $\left(\mathrm{C}_{24}-\mathrm{C}_{30}\right)$ with a strong predominance of even-numbered carbon chains are typical constituents of higher land plant leaf waxes (Eglinton et al., 1968; Simoneit, 1978; Naraoka and Ishiwatari, 2000). Their occurrence in marine sediments is usually attributed to terrestrial inputs via riverine or eolian transport. More important for the Arctic is entrainment by ice of river-discharged terrestrial organic carbon supplied to the large Amerasian shelf areas. Ice formation over these shelf areas accompanied by sediment inclusion is a proven mechanism for example for the removal and export of sediment from the Laptev Sea shelf to the interior basins of the Arctic Ocean (Eicken et al., 2000; Schoster et al., 2000). The occurrence of LCFA within surface sediment samples of the central Arctic Eurasian Basin and the Greenland Sea, north of our investigation area, has been likewise documented (Belicka et al., 2002).

Previously (Volkman et al., 1998 and herein), however, it has been noted that microalgae and bacteria may also produce these fatty acids, but in trace amounts $(<2 \%)$ relative to $\mathrm{C}_{14}-\mathrm{C}_{20}$ fatty acids. The occurrence of long-chain saturated fatty acids, e.g. $\mathrm{C}_{24}$, has been noted also for Arctic phytoplankton and ice algae (Henderson et al., 1998). Moreover, based on stable carbon isotopic evidence (see also Section 3.3.3), Naraoka and Ishiwatari (2000) attributed significant contributions of long-chain, even numbered saturated fatty acids (e.g. $63-80 \%$ for $n-\mathrm{C}_{26}$, in marine sediments to a "non-terrestrial" source. 
In summary, the fatty acid compositions of the sediments from the Fram Strait and on the Yermak Plateau are dominated by products derived from primary production, most likely of a (sea-ice) diatom origin, as indicated by high amounts of $\mathrm{C}_{16: 1 n-7}$, $\mathrm{C}_{20: 5 n-3}, \mathrm{C}_{20: 4 n-6}$ and $\mathrm{C}_{14: 0}$. Another suite of fatty acids, attributable most likely to bacteria (branched fatty acids) and zooplankton (mainly copepods, $\mathrm{C}_{20: 1}$, $\mathrm{C}_{22: 1}$ and $\mathrm{C}_{18: 1}$ fatty acids) reflects the transfer of the initially produced organic carbon through different trophic levels. Compared to the before mentioned fatty acids of primary and secondary origin, longchain fatty acids of a probable, but not exclusive (see Section 3.3.3) higher land plant origin are of minor importance. The overall composition of the fatty acid fractions, dominated by high amounts of MUFA and PUFA indicates a "fresh" status of the organic material accumulating in surface sediments and points to a rapid export to the seafloor.

\subsection{2. n-Alkanes and n-alkanols}

$n$-Alkanes and $n$-alkanols were investigated for their supposed higher land plant origin and to provide additional measures for terrestrial-derived contributions besides the long-chain fatty acids. The $n$-alkanes from cuticular waxes of higher land plants typically range from $\mathrm{C}_{23}-\mathrm{C}_{35}$ with a distinct predominance of odd-carbon chain lengths and a concentration maximum at $\mathrm{C}_{27}, \mathrm{C}_{29}$ or $\mathrm{C}_{31}$ (Eglinton et al., 1962; Eglinton and Hamilton, 1967; Rieley et al., 1991; Kunst and Samuels, 2003). The carbon Preference Index (CPI, Bray and Evans, 1961 and others) is an expression of this odd-numbered $n$ alkane predominance, and $n$-alkane mixtures from natural vegetation waxes have high (>5) CPI (e.g. Eglinton and Hamilton, 1963). Analogous, sedimentary $n$-alkanes in the aquatic environment, when also showing a pronounced preference of long-chain $\left(>\mathrm{C}_{25}\right)$ odd-numbered homologues (and high CPI) are interpreted to derive from terrestrial organic inputs.

Within all samples investigated, the hydrocarbon fractions (Appendix B) contained $n$-alkanes from $\mathrm{C}_{15}$ to $\mathrm{C}_{32}$, usually dominated by higher homologues. Total $n$-alkanes ranged from 167 to $393 \mu \mathrm{g} /$ g TOC, revealed no major variation amongst individual stations or averages for the different subregions and were generally low compared to fatty acids (cf. Tables 1 and 2). The noticeable predominance of odd-numbered $n$-alkanes $\left(>n-\mathrm{C}_{22}\right)$ is well expressed in the corresponding CPI, ranging from 1.2 (PS57/131) to 3.0 (PS2849), whereby the CPI for 20 of the 37 samples is $>2$ (Appendix B). The sum of long-chain, odd-numbered $n$-alkanes $\left(\mathrm{C}_{25}-\right.$ $\mathrm{C}_{31}$ ) of supposed higher land plant origin varied from $43-116 \mu \mathrm{g} / \mathrm{g}$ TOC and contributed $20-47 \%$ to the total $n$-alkanes (Appendix B). Total $n$-alkane concentrations obtained within this study compare to the values from Belicka et al. (2002) for their stations $36(114 \mu \mathrm{g} / \mathrm{g}$ TOC) and $37(146 \mu \mathrm{g} / \mathrm{g}$ TOC) located in the Eurasian Basin north of our investigation area. In addition, calculation of the CPI from the $n$-alkane distributions provided by Belicka et al. (2002) gives comparable values (2.9 and 2.5) than above.

The $n$-alkanols detected in surface sediments from the Fram Strait and on the Yermak Plateau (Appendix C) consisted of even numbered compounds, ranging from $\mathrm{C}_{16}$ to $\mathrm{C}_{28}$. In most samples, the concentrations of $n$-alkanols $>\mathrm{C}_{22}$ are higher than those of short chain homologues and typically maximised in $\mathrm{C}_{26}$. Concentrations of total $n$-alkanols $(85-431 \mu \mathrm{g} / \mathrm{g}$ TOC, Table 1) were in the same order of magnitude than those of total $n$-alkanes and also compare to total $n$-alkanols (104 and $144 \mu \mathrm{g} / \mathrm{g}$ TOC) from surface sediments of the Eurasian Basin (Belicka et al., 2002). In accordance with their known dominance in plant waxes, we assumed the $n-\mathrm{C}_{22}$ to $n-\mathrm{C}_{28}$ alkanols also to reflect terrestrial contributions.

\subsubsection{Carbon isotopic composition of selected compounds}

When possible (in terms of concentrations and sufficient chromatographic resolution), compound specific stable carbon isotopic ratios were determined for fatty acids, $n$-alkanes and $n$-alkanols for 11 samples selected out of the total of 39. Instead of reporting these $\delta^{13} \mathrm{C}$ values for each station and compound investigated separately, we show the range and average carbon isotopic ratio for the different compounds in Fig. 3. For comparison, the figure also includes the range and average of $\delta^{13} \mathrm{C}_{\text {org }}$ as reported in Table 1. Although the samples investigated cover a large area, there is only a small $(\sim 3 \%)$ overall variability with respect to the ${ }^{13} \mathrm{C}$ - 


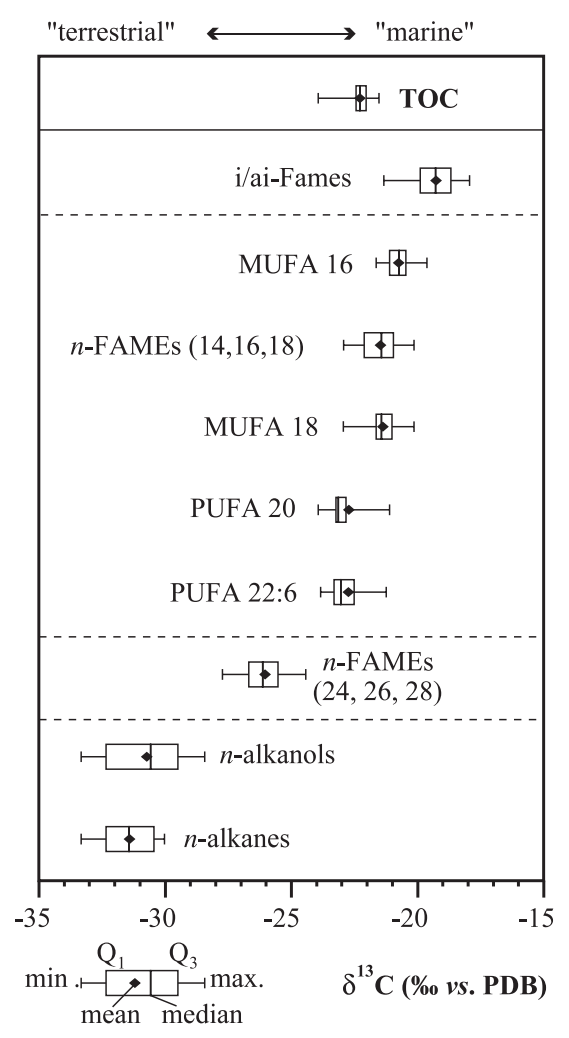

Fig. 3. $\delta^{13} \mathrm{C}$-values (range and average) of Corg and aliphatic lipids in surface sediments of the Fram Strait and on the Yermak Plateau. i/ ai-fatty acids: iso- and anteiso- $\mathrm{C}_{15}$ fatty acids; MUFA 16: $\mathrm{C}_{16: 1 n-7}$ and $\mathrm{C}_{16: 1 n-5}$ fatty acids; MUFA 18: $\mathrm{C}_{18: 1 n-9}$ and $\mathrm{C}_{18: 1 n-7}$ fatty acids; PUFA 20: $\mathrm{C}_{20: 4 n-6}$ and $\mathrm{C}_{20: 5 n-3}$ fatty acids; PUFA 22: $\mathrm{C}_{22: 6 n-3}$ fatty acid; n-alkanols: long-chain $\left(\mathrm{C}_{22}-\mathrm{C}_{26}\right)$ even carbon numbers; $n$ alkanes: long-chain $\left(\mathrm{C}_{25}-\mathrm{C}_{31}\right)$ odd carbon numbers. Given values cover 38 samples for $\delta^{13} \mathrm{C}_{\text {org }}$ and 11 samples for compound specific $\delta^{13} \mathrm{C}$-values, distributed over the entire investigation area. The standard error is shown by the box, whereas the diamond represents the mean value. The lines extending from the box are indicating the minimum/maximum values.

content of both TOC and of distinct compounds. On the other hand, $\delta^{13} \mathrm{C}$-values for the suite of compounds measured range from $-33 \%$ up to $-19 \%$.

$n$-Alkanes $\left(\mathrm{C}_{25,27,29,31}\right)$ and $n$-alkanols $\left(\mathrm{C}_{22,24,26}\right)$ are most depleted in ${ }^{13} \mathrm{C}$, ranging from $-33 \%$ to $-29 \%$ (Fig. 3). Such a carbon isotopic depletion is commonly attributed and in accordance with inputs derived from a terrestrial (higher land plant) source possessing a $\mathrm{C}_{3}$ biosynthetic pathway (Collister et al., 1994). Collister et al. (1994) and others (e.g. Huang et al., 1996; Ficken et al., 1998) also showed that biosynthetically related $n$-alkyl lipids (e.g. $n$ alkanes, $n$-alkanols, $n$-fatty acids) in epicuticular waxes of the same plant have similar carbon isotopic compositions. Therefore, the similarity in the carbon isotopic composition of the long-chain $n$-alkanols and of the long-chain $n$-alkanes in our samples (Fig. 3) most likely points to a common $\mathrm{C}_{3}$ land plant source.

The fatty acids contributing the highest proportions to the sedimentary organic carbon contents (i. e. saturated, monounsaturated, and polyunsaturated fatty acids up to $\mathrm{C}_{22}$ ) are relatively enriched in ${ }^{13} \mathrm{C}$ (Fig. 3) compared to the terrestrial $n$-alkanes and $n$ alkanols. Within the suite of fatty acids, the PUFA structures ranged from about $-24 \%$ o to $-21 \%$, saturated $\mathrm{C}_{14}-\mathrm{C}_{18}$ compounds and $\mathrm{C}_{18}$ monounsaturates from $-23 \%$ to $-20 \%$, and $\mathrm{C}_{16}$ monounsaturates from about $-22 \%$ o to $-19 \%$ o. Branched fatty acids $\left(i / a i-\mathrm{C}_{15}\right)$ were the most ${ }^{13} \mathrm{C}$-enriched, ranging from approximately $-21 \%$ o up to $-18 \%$ o (Fig. 3). The carbon isotopic compositions of all these lipids, i.e. of all $\mathrm{C}_{14}-\mathrm{C}_{22}$ fatty acids, are consistent with a marine source and are typical for lipids derived from marine organisms (e. g. Freeman et al., 1995; Pancost et al., 1997; van Dongen et al., 2002). It is known that the carbon isotopic composition of a consumer closely reflects its diet and this basic principle has been used to trace organic carbon flows through food webs (e. g. Peterson, 1999; Boschker and Middelburg, 2002). Following this concept, the carbon isotopic composition of fatty acids presumed to derive from zooplankton and bacterial sources (e. g. MUFA 18, i/ai- $\mathrm{C}_{15}$, cf. preceding section and Fig. 3) imply that organic carbon derived from primary production is their principle organic carbon source.

Long-chain fatty acids (LCFA) with even carbon atom numbers, also of a probable plant wax origin, are ${ }^{13} \mathrm{C}$ enriched by an average of $5 \%$ compared to $n$ alkanes and $n$-alkanols (Fig. 3). Their average carbon isotopic composition $(-26 \%)$ is intermediate between that observed for $n$-alkanes and $n$-alkanols ( $-33 \%$ to $-29 \%$, see above) and compounds of "marine" origin ( $-26 \%$ up to $-19 \%$ o, see below), and points towards a mixed origin for LCFA. Naraoka and Ishiwatari (2000) observed a gradual increase in ${ }^{13} \mathrm{C}$ of up to $+6 \%$ of LCFA in a section from riverine to estuarine to open ocean surface sediments and attributed this to seawards increasing contributions of 
LCFA derived from marine primary productivity. The same was concluded upon the stable carbon isotopic composition of LCFA in a recent study of the Altamaha river mouth (Shi et al., 2001).

We estimated the proportions of LCFA originating from terrestrial and marine derived sources using a simple two-endmember carbon isotopic mixing calculation, and assuming that $n$-alkyl lipids from a common source possess the same carbon isotopic composition. This is at least valid for biosynthetically related $n$-alkyl lipids in epicuticular waxes of terrestrial plants (Collister et al., 1994; Huang et al., 1996; Ficken et al., 1998). Consequently, the $\delta^{13} \mathrm{C}$ value for the higher land plant derived proportions of LCFA within the samples should be reflected by the carbon isotopic composition of the plant-derived $n$-alkanes and $n$-alkanols. As shown above, their similar carbon isotopic composition indeed indicates a common plant wax origin. As the $\mathrm{C}_{26}$ $n$-alkanol was the most abundant plant-derived alkyllipid within the samples (Appendix B, C), its $\delta^{13} \mathrm{C}$ value was choosen to reflect the terrestrial derived endmember within the mixing calculation. The second ("marine") endmember was then defined by the respective $\delta^{13} \mathrm{C}$ value of the $\mathrm{C}_{16: 1 n-7}$ fatty acid from the same sample. The measured $\delta^{13} \mathrm{C}$ value of the LCFA $\left(\delta_{\mathrm{LCFA}}\right)$ then originates from:

$\delta_{\mathrm{LCFA}}=\left(1-f_{\text {terr }}\right) \delta_{16: 1 n-7}+f_{\text {terr }} \delta \mathrm{C}_{26 n-\text { alkanol }}$

where $f_{\text {terr }}\left(0<f_{\text {terr }}<1\right)$ is the terrestrial fraction of the LCFA. The \%-proportion of terrestrial derived LCFA was then calculated by rearranging Eq. (1) into:

$$
\begin{aligned}
\mathrm{oLCFA}_{\text {terr }} & =100 f_{\text {terr }} \\
& =100 \frac{\left(\delta_{\text {LCFA }}-\delta_{16: 1 n-7}\right)}{\left(\delta C_{26 n-\text { alkanol }}-\delta_{16: 1 n-7}\right)}
\end{aligned}
$$

For the available number of samples $(n=11)$, the calculated proportions of terrestrially-derived LCFA ranged from $45 \%$ to $57 \%$ and averaged $51.5 \%$ (S.D. $=4.8)$. Given this low variability and to include those samples where compound specific carbon isotopic ratios were not measurable, a constant proportion of $51.5 \%$ (i. e. the determined mean) of the LCFA were assumed to derive from a higher land plant origin, whereas the remaining fraction is attributed to primary production.

\subsection{Processes controlling extractable organic matter composition}

Among the numerous individual aliphatic lipids detected, some must be considered to be rather unspecific with respect to a distinct source, but others have the potential to trace and differentiate at least between a "marine" and "terrestrial" origin, respectively to indicate autochthonous and allochthonous contributions. Rather than attempting to separate distinct organism groups (e.g. diatoms, dinoflagellates, sea-ice algae) contributing in varying proportions to the organic fraction of the sediments, we defined three general "lipid pools" reflecting organic carbon derived from:

(A) Primary production (marine phytoplankton, seaice algae);

(B) Secondary inputs (either by feeding of zooplankton, benthic organisms and bacteria on marine phytoplankton;

(C) Terrestrial sources (higher land plants).

The assignment of each compound to these lipid pools is based upon their structure and known occurrence within specific organisms (see Sections 3.3.1. and 3.3.2.) and was, where possible, verified by compound specific carbon isotope measurements (Section 3.3.3.). The reduction to these groups nonetheless retains all information relevant for an interpretation of the dataset with respect to the major sources and processes leading to the deposition of sedimentary lipids for the area of investigation.

The first group (A) includes compounds derived from photoautotrophic carbon fixation. In contrast to the temperate marine environment, however, in polar seas the habitat of potential primary producers is extended and includes some algae living within, on, or under the ice.

The following fatty acids identified within our sediments have been included in the pool of compounds representing primary production: $\mathrm{C}_{14: 0}$, $\mathrm{C}_{16: 1 n-7}, \mathrm{C}_{16: 1 n-5}, \mathrm{C}_{18: 4 n-3}, \mathrm{C}_{20: 4 n-6}, \mathrm{C}_{20: 4 n-3}, \mathrm{C}_{20: 5 n-3}$, and $\mathrm{C}_{22: 6 n-3}$. As revealed by their stable carbon isotopic composition, a portion of the LCFA most 
probably also derives from primary production and this fraction is included in the sum of lipids from primary production.

Compounds reflecting secondary inputs (B) comprise those lipids typical of bacteria (odd numbered straight chain, iso- and anteiso- $\mathrm{C}_{15}$ and $\mathrm{C}_{17}$-fatty acids) and zooplankton $\left(\mathrm{C}_{18: 1 n-9}, \mathrm{C}_{18: 1 n-7}, \mathrm{C}_{20: 1 n-9}\right.$, $\mathrm{C}_{20: 1 n-7}, \mathrm{C}_{22: 1 n-11 / n-9}$ ).
Terrestrial organic carbon (lipid pool "C") was traced by the summed amounts of long chain, even numbered $n$-alkanols $\left(\mathrm{C}_{22}, \mathrm{C}_{24} \mathrm{C}_{26}, \mathrm{C}_{28}\right)$ and long chain, odd numbered $n$-alkanes $\left(\mathrm{C}_{25}, \mathrm{C}_{27}, \mathrm{C}_{29}, \mathrm{C}_{31}\right)$. In addition, the higher land plant derived proportions of LCFA are also included.

Table 4 summarises the amounts of aliphatic lipids for the respective lipid pools, the percentages thereof as well as the fraction of total lipids assigned.

Table 4

Distribution of aliphatic lipids $(\mu \mathrm{g} / \mathrm{g}$ TOC) attributed to different lipid pools in surface sediments of northeastern Fram Strait, percentages (normalized to $100 \%$ ) thereof and fraction of assigned lipids

\begin{tabular}{|c|c|c|c|c|c|c|c|c|c|c|c|c|c|c|}
\hline & Transect & I & I & I & $\mathrm{I}+\mathrm{III}$ & I & I & I & I & I & I & I & I & I \\
\hline & Area & $\mathrm{AO}$ & $\mathrm{AO}$ & $\mathrm{AO}$ & YSC & YP & YP & YP & YP & YP & & & & MIZ \\
\hline Lipid pool & Station & 2849 & 2851 & 2853 & 2854 & 2855 & 2856 & 2857 & 2858 & 2859 & 2860 & 2861 & 2832 & 2831 \\
\hline Primary & & 316 & 261 & 443 & 912 & 406 & 442 & 453 & 563 & 461 & 391 & 467 & 587 & 1331 \\
\hline Secondary & & 227 & 168 & 326 & 642 & 342 & 366 & 325 & 451 & 342 & 282 & 304 & 437 & 711 \\
\hline Terrestrial & & 372 & 276 & 292 & 445 & 258 & 298 & 382 & 302 & 332 & 278 & 316 & 314 & 307 \\
\hline$\%$ Primary & & 35 & 37 & 42 & 46 & 40 & 40 & 39 & 43 & 41 & 41 & 43 & 44 & 57 \\
\hline$\%$ Secondary & & 25 & 24 & 31 & 32 & 34 & 33 & 28 & 34 & 30 & 30 & 28 & 33 & 30 \\
\hline$\%$ Terrestrial & & 41 & 39 & 28 & 22 & 26 & 27 & 33 & 23 & 29 & 29 & 29 & 23 & 13 \\
\hline$\%$ Assigned lipids & & 64 & 61 & 68 & 72 & 66 & 65 & 67 & 68 & 67 & 66 & 66 & 66 & 73 \\
\hline
\end{tabular}

\begin{tabular}{|c|c|c|c|c|c|c|c|c|c|c|c|c|c|c|}
\hline & Transect & I & II & II & II & II & II & II & II & II & II & II & III & III \\
\hline & Area & & $\mathrm{AO}$ & $\mathrm{AO}$ & YSC & YP & YP & YP & YP & MIZ & MIZ & & & YSC \\
\hline Lipid pool & Station & 2830 & 2847 & 2848 & $55 / 95$ & $55 / 97$ & 2836 & 2835 & 2834 & 2863 & 2864 & 2865 & 2838 & $55 / 98$ \\
\hline Primary & & 622 & 398 & 498 & 1723 & 654 & 469 & 554 & 653 & 607 & 917 & 575 & 553 & 2576 \\
\hline Secondary & & 356 & 271 & 374 & 837 & 379 & 379 & 398 & 291 & 374 & 522 & 329 & 396 & 550 \\
\hline Terrestrial & & 429 & 335 & 327 & 328 & 334 & 314 & 324 & 305 & 324 & 318 & 199 & 274 & 296 \\
\hline$\%$ Primary & & 44 & 40 & 42 & 60 & 48 & 40 & 43 & 52 & 47 & 52 & 52 & 45 & 75 \\
\hline$\%$ Secondary & & 25 & 27 & 31 & 29 & 28 & 33 & 31 & 23 & 29 & 30 & 30 & 32 & 16 \\
\hline$\%$ Terrestrial & & 30 & 33 & 27 & 11 & 24 & 27 & 25 & 24 & 25 & 18 & 18 & 22 & 9 \\
\hline$\%$ assigned lipids & & 65 & 66 & 65 & 74 & 67 & 68 & 70 & 69 & 67 & 65 & 71 & 68 & 76 \\
\hline
\end{tabular}

\begin{tabular}{|c|c|c|c|c|c|c|c|c|c|c|c|c|c|c|}
\hline & Transect & III & III & III & III & III & III & III & III & III & III & III & III & III \\
\hline & Area & YSC & YSC & YSC & YSC & YSC & MIZ & MIZ & OW & OW & OW & OW & OW & OW \\
\hline Lipid Pool & Station & 2837 & $55 / 93$ & $55 / 92$ & $57 / 160$ & $57 / 161$ & $55 / 77$ & $57 / 157$ & $55 / 158$ & $57 / 153$ & $57 / 123$ & $57 / 131$ & $57 / 138$ & $57 / 145$ \\
\hline Primary & & 595 & 2928 & 2236 & 3039 & 1781 & 6198 & 2190 & 1663 & 1921 & 1094 & 898 & 766 & 821 \\
\hline Secondary & & 352 & 1189 & 689 & 1714 & 632 & 1129 & 990 & 803 & 512 & 507 & 496 & 403 & 390 \\
\hline Terrestrial & & 255 & 288 & 286 & 363 & 265 & 286 & 281 & 186 & 214 & 118 & 189 & 77 & 108 \\
\hline$\%$ Primary & & 50 & 66 & 70 & 59 & 67 & 81 & 63 & 63 & 73 & 64 & 57 & 61 & 62 \\
\hline$\%$ Secondary & & 29 & 27 & 21 & 34 & 24 & 15 & 29 & 30 & 19 & 29 & 31 & 32 & 30 \\
\hline$\%$ Terrestrial & & 21 & 7 & 9 & 7 & 10 & 4 & 8 & 7 & 8 & 7 & 12 & 6 & 8 \\
\hline$\%$ assigned lipids & & 66 & 76 & 75 & 72 & 73 & 80 & 74 & 73 & 72 & 70 & 66 & 77 & 71 \\
\hline
\end{tabular}

Station locations are given in Fig. 1, for area abbreviations (AO, YP, MIZ, OW, YSC) see Table 1 and text. For definition of lipid pools see text. Notice that to account for their mixed source, amounts of LCFA as given in Appendix A have been partitioned into lipids of primary and terrestrial origin upon their carbon isotopic composition as explained in the text. \% assigned lipids is the fraction of the sum of primary, secondary and terrestrial lipids out of the total lipids (as given in Table 1). 
The relative proportions of assignable lipids varied from $61 \%$ at AO-station PS2849 to $80 \%$ at the MIZ (PS55/77) and on average comprised about 70\%.

In the subsequent sections of this paper, aliphatic lipids derived from lipid pools (A) and (B) will be also referred to as primary and secondary products, lipids or compounds. Notice however, that more generally both are also termed "marine", in contrast to compounds of a "terrestrial" origin.

\subsubsection{Distribution of lipid pools in perennially ice- covered areas (Transects I and II)}

Fig. 4 gives an overview on the distribution of primary, secondary, and terrestrial derived aliphatics and the fraction of assignable lipids in two transects across the northern Yermak Plateau. Individual numbers of the respective fractions are provided in Table 4. Most of the stations in Transects I and II derive from an area with a permanent sea-ice cover, providing a permanent shade of the upper water column, even in those times of the year when light is available in the high Arctic. While in general primary productivity is supposed to be low under such conditions (Wheeler et al., 1996), adapted algal communities growing in the bottom of the ice, at the ice-water interface, as well as phytoplankton, accounts for average primary production rates of $275 \mathrm{mg} \mathrm{C} \mathrm{m}^{-2}$ day $^{-1}$ in the Nansen Basin (Gosselin et al., 1997), north of the Yermak
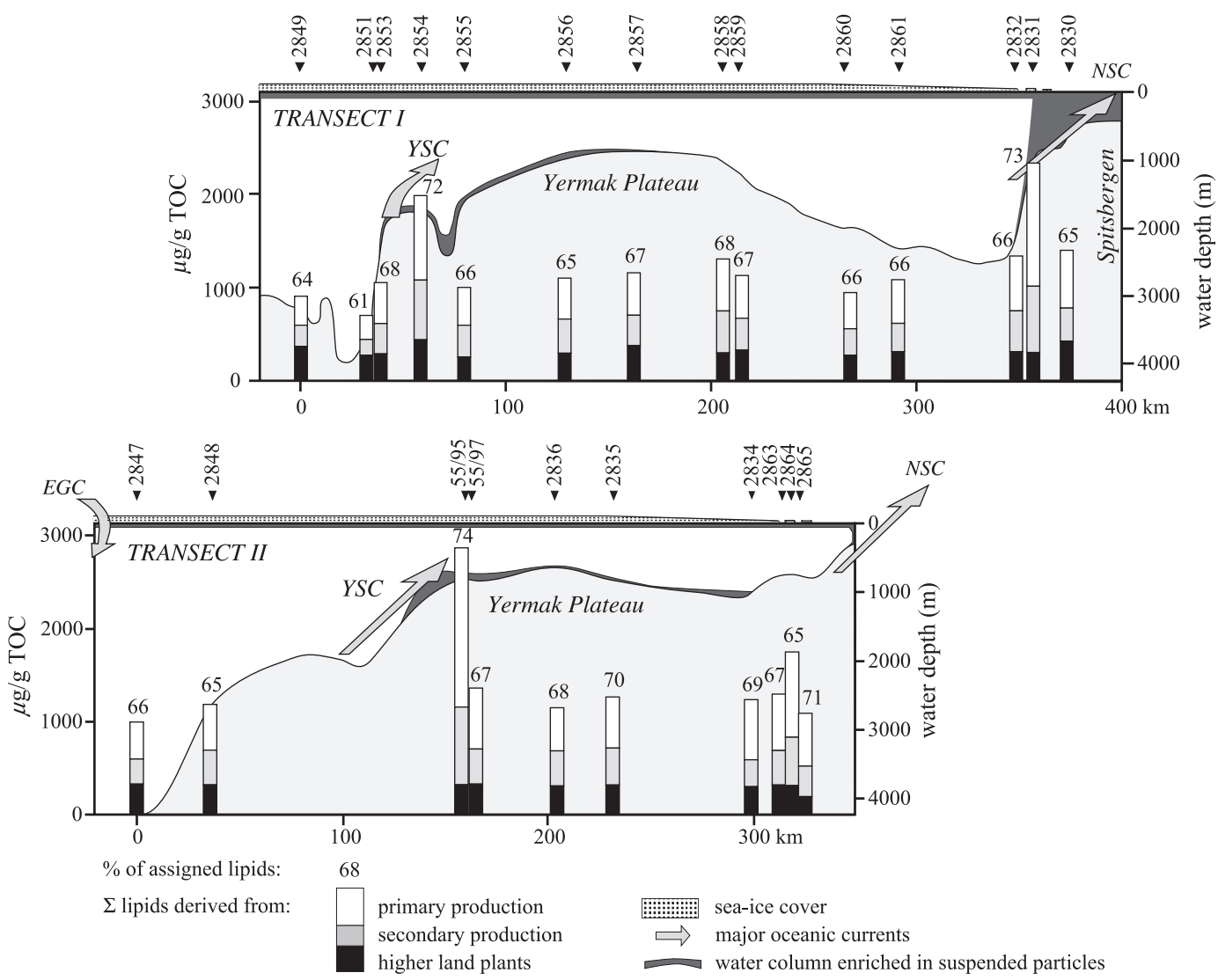

Fig. 4. Total lipids of different sources in surface sediments across the yermak Plateau. For locations of Transects I and II see Fig. 1. The thickness of ice-cover and water column parts enriched in suspension (adapted from Rutgers van der Loeff et al., 2002) is shown schematically and not scaled in vertical extension. For individual amounts of lipid pools at the respective stations see Table 4. The numbers given to the columns represent percentages of lipid pools $\mathrm{A}, \mathrm{B}$, and $\mathrm{C}$ of the total lipid amounts. 
Plateau. Approximately double this amount of carbon is produced at the MIZ of Fram Strait according to the range of values published $\left(426 \mathrm{mg} \mathrm{C} \mathrm{m}^{-2}\right.$ day $^{-1}$, Smith et al., 1987; 7-720 $\mathrm{mg} \mathrm{C} \mathrm{m}^{-2}$ day $^{-1}$, Hirche et al., 1991).

With respect to our data, lowest amounts of primary lipids were contained in surface sediments from the northernmost deep-sea stations of Transects $I$ and II (261-498 $\mu \mathrm{g} / \mathrm{g}$ TOC; PS2849-PS2953, PS2847, PS2848, Fig. 4, Table 4). In contrast, the amounts of primary produced lipids approximately doubled (917-1331 $\mu \mathrm{g} / \mathrm{g}$ TOC) in surface sediments close to the MIZ (Stations PS2864 Transect II; PS2831, Transect I; respectively, Fig. 4; Table 4). As this mirrors the differences in primary production rates when comparing ice-covered deep-sea areas and MIZ (see above), we thus can conclude that the sedimentary contents of lipids attributed to primary productivity are correlated with the surface water productivity. On the Yermak Plateau, the sum of lipids representing primary production ranged from $406-563 \mu \mathrm{g} / \mathrm{g}$ TOC (Stations 2854-2832) in Transect I and 469-654 $\mu \mathrm{g} / \mathrm{g}$ TOC (Stations PS55/ 97-PS2863) in Transect II. This compares to the amounts detected for stations under seasonally open water conditions on the shallow Spitsbergen shelf (Stations PS2830, PS2865, 622 and $575 \mu \mathrm{g} / \mathrm{g}$ TOC, respectively, Fig. 4, Table 4). On the Yermak Plateau, the concentrations of lipids recording primary production did not vary systematically, i.e. no distinct trend with increasing northwards distance from the ice-edge was observed. Except for this observation, Stations PS2854 (Transect I) and PS55/95 (Transect II), both situated on the western flank of the Yermak Plateau at comparable water depth, showed enhanced contents (912 and $1723 \mu \mathrm{g} / \mathrm{g}$ TOC) of lipids reflecting primary production, and in the case of Station PS55/95, even exceeding the amounts at the MIZ. These elevated amounts must reflect contributions from an additional source other than surface water productivity and we discuss this aspect later. Independent to our study, the above described characteristics of water and sea-ice related primary productivity recorded in surface sediments, including the anomaly on the western flank of the Yermak Plateau, have been described by means of chloroplast pigments determined at identical stations (Soltwedel et al., 2000).
The second lipid pool contained in surface sediments on the Yermak Plateau comprises compounds derived of secondary production, mainly from zooplankton and bacterial activity. Based upon traditional views on food web structures, the organic carbon source of these organisms originates from primary production, and this is supported by the similarity in the carbon isotopic composition of the fatty acids from bacteria and zooplankton compared to the fatty acids derived from primary production (see Fig. 3). However, comparison at the amounts of primary lipids and those of secondary origin (Fig. 4, Table 4) revealed an overall positive correlation, and indeed, this can be expressed by a linear relationship in the form of $\Sigma$ secondary lipids $=0.599 * \Sigma$ lipids primary production $\left(R^{2}=0.73\right)$. Thus, at all stations of Transects I and II the amounts of zooplankton and bacterial derived lipids are at about $60 \%$ of the lipids attributed to primary production. This positive correlation is surprising, as normally one would expect an inverse relationship between primary and secondary producers, i.e. a higher consumption should lower the amounts of primary produced organic carbon. As this is not observed in our case, we hypothesise that most of the primary produced lipids in surface sediments must have rapidly escaped the water column without being significantly impacted by microbial degradation and zooplankton grazing. This was already mentioned with respect to the fatty acid compositions at all stations (e.g. high ratios of $\mathrm{C}_{16: 1} / \mathrm{C}_{16: 0}$, high relative proportions of PUFA, see Section 3.3.1.). The expressed relationship of primary and secondary lipids in the surface sediments might thus be regarded as a result of effective export of a distinctive part of primary produced organic matter (aggregated phytodetritus, faster sinking and larger species, e.g. diatoms, ballasted by lithogenic matter). In contrast, another part of primary producers remains suspended in the upper water column and is available for utilisation in the bacterial and zooplankton food loop and thus reaches the seafloor as secondary lipids. Additionally, fecal pellets might provide another ballast effect leading to the rapid export of primary produced organic matter. It is known that the abundance of distinct phytoplankton species blooming at the ice-edge changes seasonally in species composition and is usually dominated by diatoms in spring (e.g. Andreassen et al., 1996). In 
summer and early autumn (September) phytoplankton is composed primarily of flagellates (Rat'kova and Wassmann, 2002). The grazing pressure of calanoid copepods in summer and autumn is much higher than in spring, because they have to accumulate large lipid reserves for overwintering. Therefore zooplankton feeding and the vertical export via zooplankton fecal pellets might be more important towards the end of the phytoplankton bloom. Diatoms can be rapidly exported from the upper water column and reach great depths, with aggregation playing a prominent role in this process (Alldredge and Jackson, 1995), whilst most flagellates remain suspended.

Although we observe distinctively lower amounts of both primary and secondary lipids over the Yermak Plateau compared to the ice-edge of both Transects (Fig. 4), this is not correlated with distance from the ice-edge in northwards direction. Rather, concentration levels remain relatively uniform up to a distance of ca. $200 \mathrm{~km}$ north of the MIZ and also compare to the levels in seasonally open waters south of the MIZ. Schlichtholz and Houssais (1999a) identified a weak influence of Atlantic water from a southern direction over the Yermak Plateau, called the Yermak Plateau Current (YPC). This Atlantic water, however was found to be denser, colder and fresher, i.e. more admixed, than the Atlantic water on the western side of the Plateau (Rudels et al., 2000), likely due to upwelling of colder waters caused by cyclonic surface circulation (Muench et al., 1992) and an intensified tidal mixing (Hunkins, 1986) over the Yermak Plateau. Though weak, this inflow leads to advection of phyto- and zooplankton (or organic matter thereof) from the more productive open waters and/or from the MIZ over the Plateau, as indicated by the presence of Atlantic diatom species and copepods (e.g. Calanus finmarchicus) from sediment traps under sea-ice (Falk-Petersen et al., 2000). In summary with admixing of the water-column by upwelling and tidal motion (see above), the overall comparable amounts of primary and secondary lipids in surface sediments on the Yermak Plateau are likewise explained. Benthic activity might serve as further explanation for the uniform and lower lipid contents on the Yermak Plateau compared to the ice-edge. We cannot evaluate reworking of organic matter by benthic meio- and macrofauna due to the lack of appropriate marker compounds. Nevertheless, reworking by benthic bacteria seems to be only of subordinate importance for the lipid distribution on the Yermak Plateau, as indicated by sedimentary bacterial fatty acids comparable in amounts to the other regions of the investigation area (Table 3). However, in relative terms, branched fatty acids are slightly enhanced $(8 \%)$ on the Yermak Plateau and Arctic Ocean stations compared to the other areas (4-5\%, Table $3)$. The same was noted by Soltwedel et al. (2000), as their data only showed a weak trend for higher proportions of bacterial biomass at stations with lower organic matter availability at the seafloor (i.e. on the Yermak Plateau and the northern, permanently ice-covered areas), whereby bacterial biomass was approximately $10 \%$ higher at northern stations.

Compared to marine primary and secondary lipids, the amounts contributed by higher land plants are low overall in Transects I and II (Fig. 4), ranging from $258-445$ and $199-335 \mu \mathrm{g} / \mathrm{g}$ TOC, respectively (Table 4). Higher concentrations in Transect I found at the southernmost station PS2830 on the shallow Spitsbergen shelf are probably derived from coastal inputs, as suggested by enhanced suspended load in this part of the Transect (see Fig. 4, Rutgers van der Loeff et al., 2002). However, compared to the amounts of terrestrial-derived compounds in sediments nearby, this supply seems to be only of local importance. In the southern part and shallow shelf region of Transect II, no signs of such a local supply of terrestrial-derived lipids were observed, in fact, concentrations of higher land plant compounds were lowest at station PS2865. Therefore, the nearby landmass seems not to be a significant source explaining the amounts of higher land plant lipids on the Yermak Plateau. Rather we presume that they derive from sea-ice transport of terrestrial derived organic matter on the Eurasian shelf areas via the Transpolar Drift. CPI values of suspended matter transported from the $\mathrm{Ob}$ and Yenisei rivers to the Kara Sea are up to 6.5 (Hefter, unpublished data) and range from three to four in surface sediments of the northern Kara Sea (Fernandes and Sicre, 2000). Ice exiting the Kara Sea to the north will influence the Fram Strait, Svalbard, and Barents Sea regions and was proposed as a potential transport agent of 
contaminants entrained from atmospheric, marine, and riverine sources with a mean travel time of 23 years for a piece of ice from the Kara Sea to Fram Strait (Pfirman et al., 1997 and references therein). In the Fram Strait, no direct riverine input of fresh terrestrially derived material is expected due to the lack of major rivers nearby. The CPI values in surface sediment samples of the ice-covered Fram Strait and on the Yermak Plateau range from 1.8 to 3.0 (Appendix B). The somewhat reduced CPI, compared to values of the proposed Kara Sea source area, might thus result from (microbial) reworking during sea-ice transport lasting several years. Based on the sedimentary CPI values, we also suspect the atmospheric transport and direct deposition of terrestrial organic matter to the Fram Strait is of minor importance, as atmospheric input of land-derived compounds to the ocean takes place in a matter of days (Gagosian and Peltzer, 1985), whereby higher CPI values (e.g. up to 7.6 in dust samples over the central eastern Atlantic; Schefuß et al., 2003) are normally preserved.

In both Transects, stations on the western flank of the Yermak Plateau differed from the general trends of lipid distribution and from stations nearby. At station PS2854 (Transect I), the amounts of lipids derived from primary and secondary produc- tion were enhanced (912 and $642 \mu \mathrm{g} / \mathrm{gTOC}$, respectively) and comparable to the amounts found at the MIZ (albeit in a distance of $250 \mathrm{~km}$ ) than surrounding stations. This was even more obvious for station PS55/95 of Transect II (Fig. 4), as there the concentrations of primary and secondary lipids even exceeded those of the MIZ (stations PS2863, PS2864). These locally enhanced abundances of marine lipids cannot be easily explained by a supply exclusively from the upper water column, and likely are sourced elsewhere.

\subsubsection{Distribution of lipid pools tracking the WSC/} YSC inflow (Transect III)

Samples included in Transect III were chosen at about a constant water depth $(1000-2000 \mathrm{~m})$ to follow the Atlantic water inflow from the WSC at the southern tip of Spitsbergen $\left(77^{\circ} \mathrm{N}\right)$ and the YSC up to $82^{\circ} \mathrm{N}$ at the northwestern flank of the Yermak Plateau. Fig. 5 shows the distribution of the respective lipid pools along this Transect in conjunction with intermediate to deep currents. Compared to Transects I and II (Fig. 4), it is obvious that, with the exception of terrestrial inputs, the distribution of lipid classes behaves differently. The overall variability is greater, but also lipids reflecting primary production reach higher amounts.

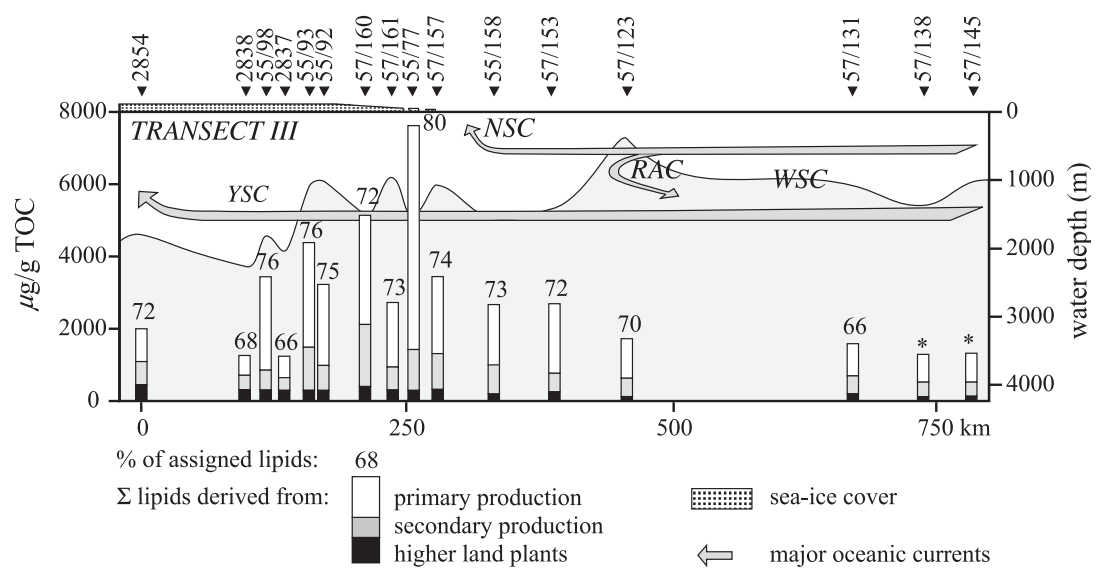

Fig. 5. Total lipids of different sources in surface sediments following the inflow of Atlantic water in eastern Fram Strait from $76^{\circ} \mathrm{N}$ to $82^{\circ} \mathrm{N}$ to the western flank of the Yermak Plateau. For locations of stations see Fig. 1. The thickness of the ice-cover is schematically and not scaled in vertical extension. For individual amounts of lipid pools at the respective stations see Table 4. The numbers given to the columns represent percentages of lipid pools A, B, and C of the total lipid amounts. *Amounts of higher land plant lipids slightly underrepresented, as $n$-alkanes were not determined. 
Station PS2854, which was discussed in the Transect I survey, is also included in Transect III and can be used for direct comparison. Relative to most other stations in Transect III this station has lower amounts of primary and secondary lipids. The northernmost station PS2854 nonetheless contains primary and secondary lipids in contents equal or even slightly higher than open water stations in the south on the western Spitsbergen shelf $(57 / 131 ; 57 /$ 138, 57/145, Fig. 5). From sediment traps deployed north and west of Spitsbergen (Andreassen et al., 1996; Owrid et al., 2000) it was found, that vertical export of marine phytoplankton and fecal pellet aggregations are (a) higher in open water areas than under sea-ice, (b) lower than at the MIZ and (c) that the highest variability occurs at the MIZ. This can be seen as a basic conceptual model with respect to the distribution of primary productivity and associated vertical fluxes in sections from permanent ice-cover to the MIZ to open water conditions, as also proposed for the Greenland Sea (Peinert et al., 2001). In line with this model, highest total lipid concentrations of primary production at station PS55/77 argue for a direct benthic-pelagic coupling, i.e. the surface sedimentary lipid record at this station reflects enhanced primary production and export from the MIZ. This also seems to be true for the southern, open water part of Transect III. The increase in surface sedimentary lipids derived from primary production (comparing open water stations PS57/145-PS57/123 (766-1094 $\mu \mathrm{g} / \mathrm{g}$ TOC) with open-water stations close to the MIZ PS57/157-PS57/153 (1663-1921 $\mu \mathrm{g} / \mathrm{g}$ TOC) might thus indicate a higher productivity at northern open water stations. This could be explained by a higher availability of nutrients closer to the MIZ due to upwelling and ice-melt. However, examination of the contents of marine lipids in surface sediments starting from the MIZ in northwards direction under the ice, the whole region on the western flank of the Yermak Plateau behaves, for at least a distance of about $200 \mathrm{~km}$, different than expected. Starting from the ice-edge at station PS55/ 77 , the surface sedimentary amounts of primary lipids are (a) comparable and even higher than at the open water stations, (b) highly variable and (c) show a distinct decrease in concentration with increasing distance from the MIZ. Thus, in contrast to the MIZ and the open water stations and also in contrast to most stations of Transects I and II, the distribution of primary lipids is clearly unrelated to upper water column productivity. Rather, their distribution on the western slope of the Yermak Plateau seems to be primarily coupled to the Yermak Slope Current. Recently it was described that this current causes a distinct benthic nepheloid layer (BNL) along the western flank of the Yermak Plateau (Rutgers van der Loeff et al., 2002, see also Fig. 4). By measuring ${ }^{234} \mathrm{Th}$ depletion in the bottom water mass of the Yermak slope, these authors also provided evidence for the existing of a settling-resuspension loop in the order of 80-120 mg suspension $\mathrm{m}^{-2}$ day $^{-1}$ and with an average particle residence time of 1-2 months within the BNL. In the surface sediments ${ }^{234} \mathrm{Th}$ is enriched, indicating removal of particulate matter from the BNL. Elevated numbers of suspension feeders in the Yermak slope and high amounts of fresh organic matter (chlorophyll- $a$ ) in the surface sediments indicate a major lateral advection of primary produced matter (Soltwedel et al., 2000; Rutgers van der Loeff et al., 2002). At stations north of the sea-ice cover, primary produced material concentrations (2000-4000 $\mu \mathrm{g} / \mathrm{g}$ TOC) exceeded those from neighbouring Yermak Plateau stations. The influence of the YSC, however, monotonically decreases with increasing distance from the MIZ, suggesting a gradually weakening velocity of the YSC. Nevertheless the lateral advection of allochthonous particulate organic matter via the $\mathrm{WSC} / \mathrm{YSC}$ appears to be the major process controlling deposition of primary and secondary produced organic matter in surface sediments of this permanently icecovered and low productive zone of the northern Fram Strait (Figs. 4 and 5).

\subsection{3. "Marine" vs. "terrigenous" organic matter}

The proportions of marine and terrestrial organic carbon in the Arctic shelf, adjacent continental slope and also central Arctic basin sediments have been estimated using a variety of organic-geochemical approaches. These studies generally indicate that organic carbon in most of these settings is dominated (i.e. $>50 \%$ ) by allochthonous, river-supplied terrestrial organic carbon (Schubert and Stein, 1997; Macdonald et al., 1998; Stein and Fahl, 2000; Mueller-Lupp et al., 2000; Goñi et al., 2000; Belicka et al., 2002, amongst others). Based on 
bulk stable carbon isotopic evidence, however, Schubert and Calvert (2001) calculated that the terrestrial fraction in eastern central Arctic surface sediments and on the Yermak Plateau could be as low as $30 \%$, although the same authors calculated terrestrial organic carbon contributions as high as $48 \%$ (using $\mathrm{C}_{\text {org }} / \mathrm{N}_{\text {org }}$ ratios).

The average proportions for the three distinctive lipid pools are summarised for the different regions of the study area (Fig. 6). Overall, primary and secondary marine lipids dominate relative to terrestrial-derived lipids in the surface sediments. Surface sediments in the northernmost, permanently ice-covered areas (AO, Arctic Ocean $>2000 \mathrm{~m}$ water depth; YP, Yermak Plateau $<1000$ m water depth) exhibited highest contributions of terrestrial-derived compounds (27-33\%) (Fig. 6). Apart of this, the region influenced by the Yermak Slope Current (YSC), compa-

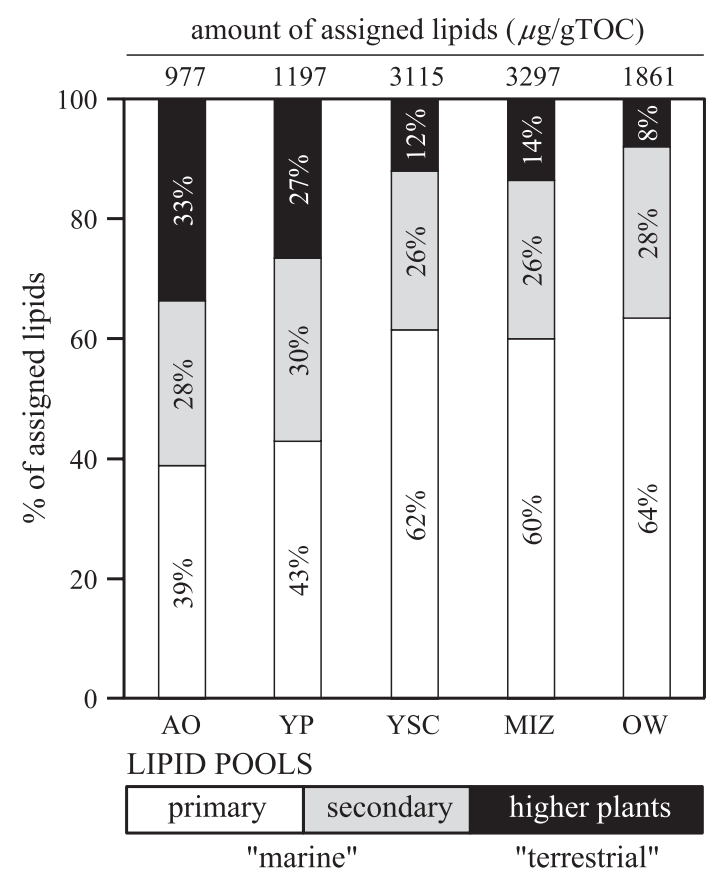

Fig. 6. Relative mean proportions of lipid pools for different areas in northeastern Fram Strait. Numbers on top represent mean total amount of the summed fractions. AO: Arctic Ocean (>2000 m), YP: Yermak Plateau (1000-1500 m), MIZ: Marginal Ice Zone, OW: Open water, YSC: Yermak Slope Current. Individual percentages for all stations are given in Table 4. rable in ice-cover and positioning to the $\mathrm{YP}$, on average contained only $11 \%$ terrestrial lipids. Similarly, areas located further south, (MIZ, OW, Fig. 6) also contained only about $8-9 \%$ terrestrial-derived compounds, despite their proximity to the Spitsbergen shelf.

The subdivision of marine-derived compounds into those of primary and secondary origin revealed a relative constant percentage $(26-30 \%)$ of secondary lipids for all areas. Highest absolute amounts of total lipids but also from primary production (see numbers on top of Fig. 6) are from open water and Atlantic water influenced regions. This might indicate that the zooplankton and bacterial community is not able to utilize the locally enhanced primary productivity at the eastern Fram Strait and especially at the MIZ with similar efficiency than in heterotrophic communities in areas of lower productivity.

It is interesting to note that assignment of both, primary and secondary lipids as marine-derived compounds, results in terrestrial contributions for the northernmost part of the study area $(27-33 \%)$ similar in proportion to that obtained from bulk organic carbon isotopic compositions in the adjacent central Arctic Ocean. Additionally, we also observed a gradual increase in the terrestrial proportions towards the Central Arctic Ocean (also expressed in the $27 \%$ vs. $33 \%$ difference between YP and AO, Fig. 6). It is also notable that if the fraction of secondary lipids was not accounted for it would enhance the estimated terrestrial proportions for some samples to $>50 \%$ (cf. Table 4). For the deeper parts of the investigation area and also for most parts of the northeastern Yermak Plateau, our data are thus consistent with previous estimates. However, enhanced marine contributions (mean $60-64 \%$, max. $81 \%$, Fig. 6, Table 4) at the MIZs and open waters northwest and north off Spitsbergen clearly differentiates this Arctic Ocean shelf region from the Siberian shelves.

\section{Conclusions}

Spatial variations in the molecular and carbon isotopic composition of the aliphatic lipid fraction in surface sediments from the northeastern Fram Strait 
and on the Yermak Plateau provide important information about organic carbon depositional processes. About $80 \%$ of the identified lipids could be assigned to one of three lipid pools, based on chemical structure and carbon isotopic composition: (a) primary production, (b) secondary origin (zooplankton, bacteria) and (c) terrestrial-derived compounds. Most of the inferred origins of specific lipids were supported by their carbon isotopic composition, however LCFA of supposed higher land plant origin appeared to reflect a mixture of marine and terrestrial inputs. The northeastern Fram Strait and the Yermak Plateau is dominated by considerable amounts of autochthonous marine carbon from both, primary (mainly diatoms) and secondary (zooplankton, bacteria) producers. A significant fraction of lipids derived from primary production successfully escapes degradation in the water column and dominates over secondary lipids, suggesting an important surface water-benthic coupling. Maximum marine biomarker concentrations in surface sediments close to, or at the ice-edge northwest and north off Spitsbergen reflected the development of large phytoplankton blooms associated with the MIZ. Sediments from the western Yermak Slope are outstanding from the organic matter record of the MIZ, but also in contrast to stations nearby on the shallower Yermak Plateau of equivalent ice-conditions and low productivity. This specific area on the western flank of the Yermak Slope is influenced by a current-driven lateral advection of particulate organic matter in a northwards direction. We found a lipid signature characteristic of the MIZ over distances up to 200 $\mathrm{km}$ from the MIZ. We suggest a qualitative and quantitative effective transport in a suspension-resuspension settling-loop. With increasing distance from the MIZ, however, the transport and deposition of marine organic matter decreases towards north, indicating a gradual weakening of the current velocity.
Terrestrial lipids are also supplied to this area, but provide only a minor fraction because of the overall strong imprint of primary and secondary lipids. The presence of these terrestrial compounds indicates the export from plant wax derived material to the Yermak Plateau and eastern Fram Strait. As the absolute concentrations of terrestrial lipids are roughly constant throughout the region, the terrestrial contribution represents a diffuse background signal, most probably as a result of long range sea-ice transport from the north, with minor contributions of the nearby Spitsbergen landmass. The imposed signal of primary and secondary production is notably weaker downslope the northern Yermak Plateau towards the deeper $(>2000 \mathrm{~m})$ central Arctic Ocean. As a consequence, the proportion of terrestrial lipids increases up to about $40 \%$ towards values previously recognised in the deep central Arctic basins.

This study shows that organic-geochemical molecular and isotopic measurements can provide an enhanced insight in organic carbon dynamics, but also pinpoint the influence of ocean-currents for the preservation and long-range redistribution of marine organic matter in sediments.

\section{Acknowledgements}

The captain and crew of $\mathrm{R} / \mathrm{V}$ Polarstern are acknowledged for their cooperation during cruises ARK-XV/2 and ARK-XVI/1 and 2. T. Eglinton, M. Yunker, and an anonymous reviewer provided critical and valuable comments and discussion significantly improving an earlier version of the manuscript. We thank P. Weller, W. Luttmer, and B. von Seggern for experienced technical assistance. This is AWI publication no. awi-n11273.

Associate editor: Dr. Timothy I. Eglinton. 


\section{Appendix A}

Concentrations $(\mu \mathrm{g} / \mathrm{g}$ TOC), percentual composition and ratios of fatty acids in surface sediments from the eastern Fram Strait and on the Yermak Plateau

\begin{tabular}{|c|c|c|c|c|c|c|c|c|c|c|c|c|c|c|c|}
\hline & & Transect & I & I & I & $\mathrm{I}+\mathrm{III}$ & I & I & I & I & I & I & I & I & I \\
\hline & assigned & Area & $\mathrm{AO}$ & $\mathrm{AO}$ & $\mathrm{AO}$ & YSC & YP & YP & YP & YP & YP & & & & MIZ \\
\hline Compound & lipid pool & Station & 2849 & 2851 & 2853 & 2854 & 2855 & 2856 & 2857 & 2858 & 2859 & 2860 & 2861 & 2832 & 2831 \\
\hline \multicolumn{16}{|l|}{ n-Saturates } \\
\hline 14 & A & & 40 & 32 & 48 & 98 & 44 & 54 & 46 & 57 & 48 & 43 & 54 & 78 & 113 \\
\hline 15 & B & & 13 & 10 & 15 & 28 & 13 & 16 & 13 & 17 & 15 & 13 & 13 & 19 & 24 \\
\hline 16 & & & 153 & 119 & 169 & 339 & 161 & 190 & 185 & 230 & 189 & 157 & 183 & 263 & 436 \\
\hline 17 & B & & 4 & 6 & 9 & 23 & 10 & 10 & 6 & 9 & 8 & 9 & 5 & 7 & 30 \\
\hline 18 & & & 47 & 34 & 41 & 70 & 31 & 37 & 43 & 40 & 37 & 34 & 34 & 41 & 72 \\
\hline 20 & & & 28 & 19 & 19 & 33 & 16 & 20 & 29 & 23 & 22 & 20 & 21 & 24 & 22 \\
\hline 21 & & & 7 & 5 & 4 & 6 & 7 & 6 & 5 & 6 & 4 & 7 & 6 & 6 & 11 \\
\hline 22 & & & 35 & 25 & 26 & 47 & 27 & 30 & 36 & 36 & 32 & 31 & 28 & 37 & 32 \\
\hline 23 & & & 11 & 4 & 9 & 19 & 12 & 12 & 14 & 13 & 13 & 10 & 14 & 12 & 11 \\
\hline 24 & $\mathrm{~A}+\mathrm{C}$ & & 54 & 55 & 59 & 115 & 62 & 68 & 70 & 72 & 75 & 65 & 58 & 62 & 71 \\
\hline 25 & & & 12 & 12 & 12 & 18 & 11 & 14 & 20 & 15 & 17 & 15 & 17 & 19 & 14 \\
\hline 26 & $\mathrm{~A}+\mathrm{C}$ & & 57 & 56 & 59 & 104 & 55 & 60 & 63 & 68 & 67 & 63 & 60 & 61 & 60 \\
\hline 27 & & & 13 & 15 & 13 & 20 & 13 & 13 & 16 & 15 & 14 & 16 & 15 & 12 & 11 \\
\hline 28 & $\mathrm{~A}+\mathrm{C}$ & & 45 & 23 & 43 & 83 & 25 & 45 & 41 & 39 & 38 & 33 & 31 & 34 & 45 \\
\hline \multicolumn{16}{|l|}{ Monounsaturates } \\
\hline $16: 1 n-7$ & A & & 119 & 97 & 202 & 470 & 206 & 223 & 231 & 270 & 219 & 174 & 243 & 318 & 625 \\
\hline $16: 1 n-5$ & A & & 27 & 24 & 39 & 86 & 36 & 14 & 57 & 56 & 43 & 39 & 60 & 31 & 108 \\
\hline $18: 1 n-9$ & B & & 51 & 24 & 52 & 103 & 64 & 62 & 63 & 103 & 64 & 45 & 50 & 71 & 159 \\
\hline $18: 1 n-7$ & B & & 43 & 41 & 108 & 226 & 99 & 111 & 89 & 131 & 102 & 89 & 101 & 152 & 266 \\
\hline $20: 1 n-9$ & B & & 8 & 3 & 28 & 9 & 27 & 21 & 10 & 20 & 12 & 14 & 5 & 7 & 36 \\
\hline $20: 1 n-7$ & B & & 5 & 4 & 3 & 17 & 3 & 4 & 10 & 9 & 3 & 4 & 14 & 10 & 9 \\
\hline $\begin{array}{l}22: 1 n-11 \\
22: 1 n-9 *\end{array}$ & B & & 38 & 24 & 15 & 40 & 31 & 32 & 31 & 47 & 28 & 25 & 27 & 34 & 33 \\
\hline \multicolumn{16}{|l|}{ Polyunsaturates } \\
\hline $18: 2$ & & & 13 & 5 & 9 & 13 & 11 & 27 & 30 & 38 & 16 & 9 & 25 & 48 & 30 \\
\hline $18: 4 n-3$ & A & & 34 & 26 & 36 & 47 & 22 & 18 & 6 & 26 & 29 & 24 & 9 & 24 & 38 \\
\hline $20: 2$ & & & 10 & 8 & 8 & 12 & 7 & 9 & 13 & 8 & 7 & 8 & 5 & 14 & 9 \\
\hline $20: 4 n-6$ & A & & 4 & 4 & 15 & 20 & 8 & 17 & 15 & 24 & 12 & 12 & 12 & 27 & 112 \\
\hline $20: 5 n-3$ & A & & 5 & 3 & 15 & 23 & 14 & 20 & 12 & 29 & 10 & 8 & 14 & 28 & 222 \\
\hline $20: 4 n-3$ & A & & 6 & 4 & 6 & 11 & 4 & 7 & 0 & 7 & 5 & 6 & & & 13 \\
\hline $22: 6 n-3$ & A & & 5 & 6 & 4 & 11 & 3 & 5 & 2 & 7 & 8 & 7 & 3 & 5 & 15 \\
\hline \multicolumn{16}{|l|}{ Branched } \\
\hline i- 15 & B & & 23 & 19 & 36 & 70 & 35 & 41 & 40 & 42 & 42 & 31 & 31 & 50 & 53 \\
\hline ai-15 & B & & 29 & 25 & 44 & 95 & 42 & 49 & 46 & 51 & 51 & 38 & 42 & 65 & 64 \\
\hline i-17 & B & & 5 & 5 & 7 & 16 & 9 & 10 & 8 & 11 & 8 & 7 & 7 & 9 & 21 \\
\hline ai-17 & B & & 8 & 7 & 9 & 15 & 9 & 10 & 9 & 11 & 9 & 7 & 9 & 13 & 16 \\
\hline Total ( $\mu \mathrm{g} / \mathrm{g}$ TOC) & & & 952 & 744 & 1162 & 2287 & 1117 & 1255 & 1259 & 1530 & 1247 & 1063 & 1196 & 1581 & 2781 \\
\hline$\%$ assigned & & & 65 & 67 & 73 & 75 & 74 & 71 & 69 & 72 & 72 & 71 & 71 & 70 & 77 \\
\hline$\%$ saturated & & & 55 & 56 & 45 & 44 & 44 & 46 & 47 & 42 & 46 & 49 & 45 & 43 & 34 \\
\hline$\%$ MUFA & & & 31 & 29 & 38 & 42 & 42 & 37 & 39 & 42 & 38 & 37 & 42 & 39 & 44 \\
\hline$\%$ PUFA & & & 8 & 8 & 8 & 6 & 6 & 8 & 6 & 9 & 7 & 7 & 6 & 9 & 16 \\
\hline$\%$ branched & & & 7 & 8 & 8 & 9 & 9 & 9 & 8 & 8 & 9 & 8 & 7 & 9 & 6 \\
\hline \multicolumn{16}{|l|}{ Ratios } \\
\hline $16: 1 / 16: 0$ & & & 1.0 & 1.4 & 1.6 & 1.5 & 1.2 & 1.6 & 1.4 & 1.4 & 1.4 & 1.7 & 1.3 & 1.7 & \\
\hline $18: 1 / 18: 0$ & & & 1.9 & 3.9 & 4.7 & 5.3 & 4.7 & 3.5 & 5.9 & 4.5 & 3.9 & 4.4 & 5.4 & 5.9 & \\
\hline
\end{tabular}


Appendix A (continued)

\begin{tabular}{|c|c|c|c|c|c|c|c|c|c|c|c|c|c|c|c|}
\hline \multirow[b]{3}{*}{ Compound } & \multirow{3}{*}{$\begin{array}{l}\text { assigned } \\
\text { lipid pool }\end{array}$} & \multirow{2}{*}{$\begin{array}{c}\text { Transect } \\
\text { Area }\end{array}$} & \multirow[t]{2}{*}{ I } & \multirow{2}{*}{$\begin{array}{c}\mathrm{II} \\
\mathrm{AO}\end{array}$} & \multirow{2}{*}{$\begin{array}{l}\mathrm{II} \\
\mathrm{AO}\end{array}$} & \multirow{2}{*}{$\frac{\text { II }}{\text { YSC }}$} & \multirow{2}{*}{$\begin{array}{l}\text { II } \\
\mathrm{YP}\end{array}$} & \multirow{2}{*}{$\begin{array}{c}\text { II } \\
\text { YP }\end{array}$} & \multirow{2}{*}{$\begin{array}{l}\text { II } \\
\mathrm{YP}\end{array}$} & \multirow{2}{*}{$\begin{array}{c}\text { II } \\
\text { YP }\end{array}$} & \multirow{2}{*}{$\begin{array}{c}\text { II } \\
\text { MIZ }\end{array}$} & \multirow{2}{*}{$\begin{array}{c}\text { II } \\
\text { MIZ }\end{array}$} & \multirow[t]{2}{*}{ II } & \multirow[t]{2}{*}{ III } & \multirow{2}{*}{$\begin{array}{c}\text { III } \\
\text { YSC }\end{array}$} \\
\hline & & & & & & & & & & & & & & & \\
\hline & & Station & 2830 & 2847 & 2848 & $55 / 95$ & $55 / 97$ & 2836 & 2835 & 2834 & 2863 & 2864 & 2865 & 2838 & $55 / 98$ \\
\hline \multicolumn{16}{|l|}{ n-Saturates } \\
\hline 14 & A & & 78 & 48 & 65 & 99 & 62 & 49 & 55 & 42 & 68 & 110 & 55 & 66 & 200 \\
\hline 15 & B & & 20 & 12 & 17 & 19 & 14 & 14 & 17 & 13 & 14 & 22 & 11 & 19 & 29 \\
\hline 16 & & & 276 & 171 & 225 & 349 & 250 & 186 & 203 & 177 & 242 & 366 & 186 & 215 & 521 \\
\hline 17 & $\mathrm{~B}$ & & 21 & 8 & 7 & 15 & 7 & 9 & 8 & 5 & 6 & 12 & 6 & 12 & 11 \\
\hline 18 & & & 51 & 43 & 47 & 59 & 41 & 38 & 41 & 40 & 40 & 66 & 29 & 45 & 56 \\
\hline 20 & & & 27 & 23 & 25 & 21 & 9 & 22 & 20 & 20 & 22 & 30 & 13 & 18 & 25 \\
\hline 21 & & & 5 & 7 & 6 & 4 & 6 & 7 & 7 & 6 & 6 & 7 & 3 & 7 & 7 \\
\hline 22 & & & 40 & 32 & 35 & 33 & 38 & 30 & 29 & 23 & 28 & 33 & 19 & 26 & 27 \\
\hline 23 & & & 12 & 8 & 11 & 20 & 13 & 10 & 13 & 10 & 11 & 10 & 6 & 13 & 12 \\
\hline 24 & $\mathrm{~A}+\mathrm{C}$ & & 82 & 65 & 65 & 69 & 68 & 63 & 58 & 48 & 65 & 62 & 35 & 68 & 60 \\
\hline 25 & & & 19 & 17 & 17 & 15 & 22 & 12 & 12 & 18 & 21 & 17 & 8 & 14 & 20 \\
\hline 26 & $\mathrm{~A}+\mathrm{C}$ & & 81 & 64 & 69 & 65 & 72 & 54 & 49 & 54 & 70 & 62 & 32 & 65 & 61 \\
\hline 27 & & & 16 & 18 & 16 & 14 & 18 & 11 & 14 & 11 & 26 & 19 & 14 & 13 & 19 \\
\hline 28 & $\mathrm{~A}+\mathrm{C}$ & & 70 & 68 & 46 & 72 & 54 & 27 & 36 & 33 & & 39 & 38 & 40 & 38 \\
\hline Monounsaturates & & & & & & & & & & & & & & & \\
\hline $16: 1 n-7$ & $\mathrm{~A}$ & & 269 & 175 & 257 & 815 & 309 & 227 & 286 & 332 & 312 & 429 & 261 & 247 & 1012 \\
\hline $16: 1 n-5$ & $\mathrm{~A}$ & & 28 & 29 & 34 & 408 & 44 & 39 & 52 & 165 & 38 & 40 & 44 & 68 & 947 \\
\hline $18: 1 n-9$ & $\mathrm{~B}$ & & 61 & 44 & 67 & 323 & 89 & 67 & 67 & 55 & 90 & 232 & 64 & 58 & 198 \\
\hline $18: 1 n-7$ & $\mathrm{~B}$ & & 99 & 83 & 125 & 178 & 115 & 128 & 140 & 86 & 99 & 34 & 114 & 143 & 28 \\
\hline $20: 1 n-9$ & $\mathrm{~B}$ & & 23 & 9 & 7 & 19 & 14 & 9 & 15 & 7 & 9 & 16 & 21 & 15 & 24 \\
\hline $20: 1 n-7$ & $\mathrm{~B}$ & & 5 & 6 & 13 & 67 & 15 & 7 & 2 & 14 & 15 & 12 & 9 & 2 & 44 \\
\hline $\begin{array}{l}22: 1 n-11 \\
22: 1 n-9 *\end{array}$ & B & & 33 & 30 & 19 & 93 & 23 & 38 & 29 & 23 & 33 & 32 & 21 & 28 & 75 \\
\hline Polyunsaturates & & & & & & & & & & & & & & & \\
\hline $18: 2$ & & & 20 & 6 & 21 & 36 & 50 & 13 & 13 & 28 & 28 & 125 & 22 & 10 & 145 \\
\hline $18: 4 n-3$ & A & & 41 & 36 & 10 & 28 & 25 & 27 & 28 & 7 & 14 & 49 & 18 & 24 & 47 \\
\hline $20: 2$ & & & 13 & & 11 & 7 & & 9 & 5 & 9 & 15 & 26 & 5 & 8 & 13 \\
\hline $20: 4 n-6$ & $\mathrm{~A}$ & & 18 & 4 & 18 & 85 & 53 & 24 & 19 & 16 & 30 & 93 & 65 & 17 & 61 \\
\hline $20: 5 n-3$ & A & & 62 & 7 & 16 & 165 & 62 & 18 & 27 & 16 & 74 & 107 & 62 & 26 & 227 \\
\hline $20: 4 n-3$ & A & & 6 & & 7 & 11 & & 7 & 5 & 7 & & & 7 & 8 & \\
\hline $22: 6 n-3$ & A & & 7 & 3 & 4 & 12 & 5 & 8 & 13 & 3 & 6 & 10 & 12 & 13 & 5 \\
\hline Branched & & & & & & & & & & & & & & & \\
\hline $\mathrm{i}-15$ & $\mathrm{~B}$ & & 30 & 28 & 41 & 47 & 36 & 42 & 45 & 32 & 39 & 57 & 29 & 43 & 48 \\
\hline ai-15 & B & & 41 & 37 & 59 & 51 & 44 & 47 & 54 & 41 & 49 & 71 & 33 & 55 & 65 \\
\hline i-17 & $\mathrm{B}$ & & 11 & 7 & 9 & 16 & 11 & 10 & 10 & 7 & 11 & 18 & 11 & 10 & 15 \\
\hline ai-17 & $\mathrm{B}$ & & 12 & 7 & 10 & 9 & 11 & 8 & 11 & 8 & 9 & 16 & 10 & 11 & 13 \\
\hline Total ( $\mu \mathrm{g} / \mathrm{g}$ TOC) & & & 1577 & 1095 & 1379 & 3224 & 1580 & 1260 & 1383 & 1356 & 1490 & 2222 & 1263 & 1407 & 4053 \\
\hline$\%$ assigned & & & 70 & 70 & 70 & 83 & 72 & 73 & 74 & 75 & 71 & 69 & 76 & 74 & 79 \\
\hline$\%$ saturated & & & 51 & 53 & 47 & 26 & 43 & 42 & 41 & 37 & 42 & 38 & 36 & 44 & 27 \\
\hline$\%$ MUFA & & & 33 & 34 & 38 & 59 & 39 & 41 & 43 & 50 & 40 & 36 & 42 & 40 & 57 \\
\hline$\%$ PUFA & & & 11 & 5 & 6 & 11 & 12 & 8 & 8 & 6 & 11 & 18 & 15 & 8 & 12 \\
\hline$\%$ branched & & & 6 & 7 & 9 & 4 & 6 & 8 & 9 & 6 & 7 & 7 & 7 & 8 & 3 \\
\hline Ratios & & & & & & & & & & & & & & & \\
\hline $16: 1 / 16: 0$ & & & 1.1 & 1.2 & 1.3 & 3.5 & 1.4 & 1.4 & 1.7 & 2.8 & 1.4 & 1.3 & 1.6 & 1.5 & 3.8 \\
\hline $18: 1 / 18: 0$ & & & 3.1 & 3.0 & 4.1 & 8.5 & 5.0 & 5.1 & 5.0 & 3.5 & 4.7 & 4.0 & 6.1 & 4.5 & 4.0 \\
\hline
\end{tabular}


Appendix A (continued)

\begin{tabular}{|c|c|c|c|c|c|c|c|c|c|c|c|c|c|c|c|}
\hline \multirow[b]{3}{*}{ Compound } & \multirow[b]{2}{*}{ assigned } & Transect & III & III & III & III & III & III & III & III & III & III & III & III & III \\
\hline & & Area & YSC & YSC & YSC & YSC & YSC & MIZ & MIZ & OW & OW & OW & OW & OW & OW \\
\hline & lipid pool & Station & 2837 & $55 / 93$ & $55 / 92$ & $57 / 160$ & $57 / 161$ & $55 / 775$ & $57 / 1575$ & $55 / 1585$ & $57 / 1535$ & $57 / 1235$ & $57 / 1315$ & $57 / 1385$ & $57 / 145$ \\
\hline \multicolumn{16}{|l|}{ n-Saturates } \\
\hline 14 & A & & 62 & 262 & 223 & 340 & 177 & 591 & 221 & 164 & 188 & 122 & 95 & 63 & 36 \\
\hline 15 & B & & 16 & 35 & 31 & 57 & 28 & 51 & 30 & 26 & 28 & 25 & 23 & 19 & 16 \\
\hline 16 & & & 218 & 719 & 572 & 1194 & 512 & 1353 & 627 & 485 & 582 & 375 & 291 & 192 & 242 \\
\hline 17 & B & & 15 & 30 & 10 & 25 & 8 & 13 & 27 & 12 & 9 & 27 & 17 & 13 & 11 \\
\hline 18 & & & 34 & 85 & 53 & 112 & 49 & 72 & 54 & 65 & 49 & 50 & 46 & 30 & 51 \\
\hline 20 & & & 15 & 22 & 21 & 48 & 20 & 23 & 31 & 39 & 19 & 12 & 16 & 11 & 22 \\
\hline 21 & & & 7 & 5 & 8 & 10 & 6 & 7 & 5 & 3 & 6 & 2 & 4 & 3 & 5 \\
\hline 22 & & & 25 & 38 & 28 & 47 & 27 & 27 & 25 & 22 & 24 & 14 & 20 & 10 & 17 \\
\hline 23 & & & 10 & 19 & 10 & 19 & 10 & 10 & 9 & 8 & 8 & 5 & 7 & 4 & 6 \\
\hline 24 & $\mathrm{~A}+\mathrm{C}$ & & 64 & 91 & 64 & 95 & 61 & 78 & 54 & 54 & 55 & 36 & 48 & 26 & 40 \\
\hline 25 & & & 11 & 10 & 18 & 27 & 14 & 14 & 15 & 10 & 13 & 5 & 6 & 7 & 10 \\
\hline 26 & $\mathrm{~A}+\mathrm{C}$ & & 61 & 70 & 62 & 99 & 58 & 61 & 57 & 52 & 57 & 25 & 45 & 22 & 46 \\
\hline 27 & & & 8 & 89 & 29 & 54 & 24 & 12 & 20 & 11 & 26 & 10 & 7 & 12 & 20 \\
\hline 28 & $\mathrm{~A}+\mathrm{C}$ & & 20 & & 33 & 88 & 33 & & 51 & & 46 & & & 49 & 15 \\
\hline \multicolumn{16}{|l|}{ Monounsaturates } \\
\hline $16: 1 n-7$ & A & & 309 & 1575 & 1256 & 1956 & 1068 & 3612 & 1307 & 940 & 1309 & 640 & 488 & 248 & 318 \\
\hline $16: 1 n-5$ & $\mathrm{~A}$ & & 64 & 81 & 90 & 86 & 61 & 93 & 125 & 58 & 65 & 66 & 72 & 235 & 273 \\
\hline $18: 1 n-9$ & B & & 129 & 406 & 150 & 1047 & 136 & 176 & 246 & 126 & 105 & 73 & 84 & 76 & 159 \\
\hline $18: 1 n-7$ & B & & 22 & 380 & 264 & 125 & 227 & 591 & 435 & 399 & 159 & 236 & 184 & 151 & 35 \\
\hline $20: 1 n-9$ & B & & 17 & 25 & 16 & 46 & 17 & 31 & 42 & 16 & 13 & 13 & 18 & 14 & 15 \\
\hline $20: 1 n-7$ & B & & 6 & 80 & 28 & 39 & 31 & 36 & 51 & 51 & 25 & 13 & 44 & 28 & 41 \\
\hline $\begin{array}{l}22: 1 n-11 \\
22: 1 n-9 *\end{array}$ & B & & 31 & 44 & 33 & 36 & 31 & 92 & 22 & 29 & 27 & 5 & 11 & 6 & 28 \\
\hline \multicolumn{16}{|l|}{ Polyunsaturates } \\
\hline $18: 2$ & & & 58 & 38 & 70 & 123 & 63 & 97 & 67 & 59 & 63 & 15 & 23 & 26 & 93 \\
\hline $18: 4 n-3$ & A & & 11 & 96 & 36 & 76 & 59 & 231 & 74 & 19 & 72 & 40 & 36 & 27 & 26 \\
\hline $20: 2$ & & & 7 & 6 & 24 & 98 & 22 & 63 & 21 & 38 & 23 & 14 & 4 & 16 & 32 \\
\hline $20: 4 n-6$ & A & & 31 & 288 & 111 & 208 & 78 & 800 & 87 & 140 & 53 & 59 & 48 & 66 & 47 \\
\hline $20: 5 n-3$ & A & & 36 & 500 & 432 & 197 & 256 & 773 & 224 & 282 & 150 & 129 & 94 & 65 & 45 \\
\hline $20: 4 n-3$ & A & & 6 & 38 & & 28 & & 15 & 64 & & & & 7 & & 22 \\
\hline $22: 6 n-3$ & A & & 6 & 10 & 11 & 11 & 8 & 16 & 9 & 9 & 7 & 8 & 13 & 15 & 5 \\
\hline \multicolumn{16}{|l|}{ Branched } \\
\hline $\mathrm{i}-15$ & B & & 44 & 71 & 53 & 74 & 57 & 49 & 47 & 43 & 50 & 37 & 41 & 33 & 28 \\
\hline ai-15 & B & & 48 & 79 & 56 & 96 & 67 & 51 & 54 & 55 & 66 & 51 & 47 & 32 & 32 \\
\hline $\mathrm{i}-17$ & B & & 13 & 23 & 24 & 101 & 18 & 21 & 20 & 24 & 16 & 14 & 16 & 11 & 17 \\
\hline ai-17 & B & & 11 & 16 & 24 & 68 & 12 & 18 & 16 & 22 & 14 & 13 & 11 & 20 & 8 \\
\hline Total ( $\mu \mathrm{g} / \mathrm{g}$ TOC) & & & 1415 & 5231 & 3840 & 6630 & 3238 & 9077 & 4137 & 3261 & 3327 & 2134 & 1866 & 1530 & 1761 \\
\hline$\%$ assigned & & & 72 & 80 & 78 & 74 & 77 & 82 & 79 & 77 & 76 & 76 & 77 & 80 & 72 \\
\hline$\%$ saturated & & & 40 & 28 & 30 & 33 & 32 & 25 & 30 & 29 & 33 & 33 & 33 & 30 & 30 \\
\hline$\%$ MUFA & & & 41 & 50 & 48 & 50 & 49 & 51 & 54 & 50 & 51 & 49 & 48 & 50 & 49 \\
\hline$\%$ PUFA & & & 11 & 19 & 18 & 11 & 15 & 22 & 13 & 17 & 11 & 12 & 12 & 14 & 15 \\
\hline$\%$ branched & & & 8 & 4 & 4 & 5 & 5 & 2 & 3 & 4 & 4 & 5 & 6 & 6 & 5 \\
\hline \multicolumn{16}{|l|}{ Ratios } \\
\hline $16: 1 / 16: 0$ & & & 1.7 & 2.3 & 2.4 & 1.7 & 2.2 & 2.7 & 2.3 & 2.1 & 2.4 & 1.9 & 1.9 & 2.5 & 2.4 \\
\hline $18: 1 / 18: 0$ & & & 4.4 & 9.2 & 7.8 & $8 \quad 10.5$ & 7.4 & 10.7 & 12.6 & 8.1 & 5.4 & 6.2 & 5.8 & 7.6 & 3.8 \\
\hline
\end{tabular}

Station locations are given in Fig. 1, for area abbreviations (AO, YP, YSC, MIZ, OW) see text and Table 1. *=sum of both isomers, MUFA=monounsaturated fatty acids, PUFA=polyunsaturated fatty acids. Letters A, B, C indicate assignment of fatty acids to the lipid pools explained in Section 3.4, \% assigned is the fraction of the sum thereof to the total fatty acids. Notice that the amounts of long chain $n$-saturates represent a mixture of lipid pools A and $\mathrm{C}$, as revealed by their stable carbon isotopic composition (see Section 3.3.3). 


\section{Appendix B}

Concentrations ( $\mu \mathrm{g} / \mathrm{g}$ TOC) of $n$-alkanes and CPI in surface sediments from the eastern Fram Strait and on the Yermak Plateau

\begin{tabular}{|c|c|c|c|c|c|c|c|c|c|c|c|c|c|c|c|}
\hline \multirow[b]{3}{*}{ n-Alkane } & \multirow[b]{2}{*}{ assigned } & Transect & I & I & I & $\mathrm{I}+\mathrm{III}$ & I & I & I & I & I & I & I & I & I \\
\hline & & Area & $\mathrm{AO}$ & $\mathrm{AO}$ & $\mathrm{AO}$ & YSC & YP & YP & YP & YP & YP & & & & MIZ \\
\hline & lipid pool & Station & 2849 & 2851 & 2853 & 2854 & 2855 & 2856 & 2857 & 2858 & 2859 & 2860 & 2861 & 2832 & 2831 \\
\hline 15 & & & 0.5 & 1.1 & 0.9 & 1.6 & 5.0 & 4.0 & & 1.4 & 1.1 & 0.7 & 2.3 & 1.4 & 1.6 \\
\hline 16 & & & 2.5 & 4.9 & 4.0 & 5.4 & 11.5 & 9.9 & 1.3 & 5.7 & 4.9 & 4.1 & 6.4 & 4.8 & 7.2 \\
\hline 17 & & & 6.7 & 9.5 & 8.9 & 8.0 & 15.2 & 15.0 & 6.6 & 10.3 & 10.5 & 9.0 & 11.4 & 10.7 & 11.9 \\
\hline 18 & & & 8.6 & 12.3 & 10.7 & 10.6 & 15.2 & 15.1 & 9.9 & 11.7 & 12.3 & 12.1 & 13.0 & 11.7 & 15.9 \\
\hline 19 & & & 12.2 & 16.0 & 13.9 & 14.6 & 20.0 & 20.3 & 14.6 & 15.9 & 16.3 & 16.3 & 16.0 & 14.5 & 23.2 \\
\hline 20 & & & 11.6 & 14.4 & 13.0 & 11.4 & 15.7 & 16.1 & 13.6 & 13.0 & 14.2 & 14.8 & 14.8 & 14.0 & 17.2 \\
\hline 21 & & & 15.1 & 15.8 & 14.6 & 12.5 & 16.5 & 17.2 & 15.9 & 14.8 & 15.8 & 16.6 & 16.5 & 15.9 & 18.4 \\
\hline 22 & & & 14.3 & 15.0 & 13.7 & 11.6 & 16.0 & 16.3 & 15.0 & 14.3 & 15.2 & 15.3 & 15.2 & 15.0 & 17.8 \\
\hline 23 & & & 20.8 & 18.1 & 17.0 & 13.2 & 18.0 & 18.9 & 19.7 & 17.3 & 18.5 & 19.0 & 19.5 & 19.8 & 19.6 \\
\hline 24 & & & 13.4 & 13.1 & 12.5 & 10.0 & 13.4 & 13.8 & 13.9 & 12.3 & 13.5 & 13.6 & 13.7 & 14.0 & 14.8 \\
\hline 25 & C & & 22.5 & 18.1 & 17.3 & 12.8 & 17.6 & 18.6 & 21.2 & 18.0 & 19.1 & 18.9 & 19.6 & 20.5 & 19.0 \\
\hline 26 & & & 11.0 & 10.9 & 10.7 & 8.5 & 11.6 & 11.9 & 11.8 & 10.6 & 11.4 & 11.2 & 11.2 & 11.7 & 12.2 \\
\hline 27 & $\mathrm{C}$ & & 29.5 & 21.8 & 20.5 & 14.5 & 20.3 & 21.9 & 27.4 & 22.9 & 23.5 & 22.5 & 24.1 & 25.4 & 21.7 \\
\hline 28 & & & 8.5 & 9.6 & 9.1 & 7.5 & 10.2 & 10.4 & 10.3 & 9.6 & 10.2 & 9.8 & 9.4 & 10.3 & 11.0 \\
\hline 29 & C & & 33.1 & 23.2 & 22.0 & 15.4 & 21.2 & 23.5 & 31.0 & 24.8 & 25.4 & 23.9 & 25.5 & 26.7 & 23.1 \\
\hline 30 & & & 5.0 & 6.4 & 5.9 & 5.1 & 6.8 & 7.2 & 7.1 & 6.7 & 7.0 & 6.4 & 6.4 & 7.0 & 7.6 \\
\hline 31 & C & & 31.1 & 20.9 & 19.7 & 14.0 & 18.3 & 20.4 & 28.8 & 22.0 & 22.9 & 21.2 & 22.6 & 24.1 & 19.3 \\
\hline 32 & & & 2.8 & 3.7 & 3.6 & 3.1 & 4.3 & 4.4 & 4.0 & 3.9 & 4.0 & 3.7 & 3.6 & 4.0 & 4.8 \\
\hline Total ( $\mu \mathrm{g} / \mathrm{gTOC})$ & & & 249.2 & 234.8 & 218.0 & 179.8 & 256.8 & 264.9 & 252.1 & 235.2 & 245.8 & 239.1 & 251.2 & 251.5 & 266.3 \\
\hline$\Sigma$ assigned to $C \mu \mathrm{g} / \mathrm{gTO}$ & & & 116.2 & 84.0 & 79.5 & 56.7 & 77.4 & 84.4 & 108.4 & 87.7 & 90.9 & 86.5 & 91.8 & 96.7 & 83.1 \\
\hline$\%$ assigned to $\mathrm{C}$ & & & 47 & 36 & 36 & 32 & 30 & 32 & 43 & 37 & 37 & 36 & 37 & 38 & 31 \\
\hline CPI $(22-32)$ & & & 3.0 & 2.1 & 2.1 & 1.8 & 1.9 & 1.9 & 2.5 & 2.2 & 2.1 & 2.1 & 2.3 & 2.2 & 1.8 \\
\hline
\end{tabular}

\begin{tabular}{|c|c|c|c|c|c|c|c|c|c|c|c|c|c|c|c|}
\hline & & Transect & I & II & II & II & II & II & II & II & II & II & II & III & III \\
\hline & assigned & Area & & $\mathrm{AO}$ & $\mathrm{AO}$ & YSC & YP & YP & YP & YP & MIZ & MIZ & & & YSC \\
\hline n-Alkane & lipid pool & Station & 2830 & 2847 & 2848 & $55 / 95$ & $55 / 97$ & 2836 & 2835 & 2834 & 2863 & 2864 & 2865 & 2838 & $55 / 98$ \\
\hline 15 & & & 3.8 & 1.1 & 2.7 & 3.2 & 2.8 & 0.2 & 1.7 & 2.5 & 2.8 & 0.9 & 2.1 & 2.4 & 4.7 \\
\hline 16 & & & 11.9 & 4.3 & 8.1 & 9.6 & 7.4 & 2.9 & 5.1 & 7.7 & 6.8 & 4.3 & 6.0 & 6.7 & 11.4 \\
\hline 17 & & & 18.3 & 7.1 & 13.0 & 14.4 & 9.9 & 8.2 & 8.5 & 10.8 & 9.8 & 9.3 & 7.8 & 11.3 & 14.8 \\
\hline 18 & & & 19.4 & 10.3 & 14.4 & 15.4 & 14.4 & 11.4 & 9.9 & 12.6 & 13.6 & 12.2 & 8.9 & 12.4 & 17.6 \\
\hline 19 & & & 26.3 & 14.1 & 19.9 & 23.4 & 18.4 & 15.4 & 13.3 & 17.8 & 19.0 & 16.4 & 13.3 & 16.1 & 22.3 \\
\hline 20 & & & 20.3 & 13.2 & 16.0 & 16.2 & 16.6 & 14.1 & 11.4 & 13.8 & 15.2 & 14.6 & 9.3 & 13.8 & 18.3 \\
\hline 21 & & & 21.9 & 15.3 & 17.6 & 17.4 & 17.9 & 16.0 & 12.9 & 15.7 & 17.1 & 16.1 & 10.3 & 15.0 & 19.9 \\
\hline 22 & & & 21.1 & 14.6 & 16.4 & 19.4 & 16.4 & 15.0 & 12.0 & 15.5 & 16.1 & 14.8 & 11.4 & 14.0 & 18.0 \\
\hline 23 & & & 24.1 & 19.4 & 19.4 & 19.1 & 19.8 & 18.7 & 16.4 & 19.3 & 19.9 & 18.3 & 11.8 & 17.1 & 21.4 \\
\hline 24 & & & 17.1 & 13.7 & 14.2 & 14.0 & 14.7 & 13.6 & 11.5 & 13.6 & 14.2 & 13.3 & 8.5 & 12.5 & 16.3 \\
\hline 25 & $\mathrm{C}$ & & 22.8 & 20.5 & 19.1 & 18.5 & 19.6 & 19.2 & 17.9 & 20.1 & 20.3 & 18.7 & 11.8 & 16.9 & 21.1 \\
\hline 26 & & & 13.8 & 11.8 & 12.1 & 12.4 & 12.5 & 11.7 & 10.0 & 11.5 & 12.1 & 11.6 & 7.6 & 10.6 & 13.7 \\
\hline 27 & $\mathrm{C}$ & & 27.1 & 24.8 & 22.7 & 21.9 & 23.2 & 24.2 & 23.4 & 25.6 & 25.4 & 23.0 & 14.5 & 20.0 & 23.9 \\
\hline 28 & & & 12.1 & 10.0 & 10.7 & 10.6 & 10.8 & 10.2 & 8.8 & 10.1 & 10.5 & 9.9 & 6.3 & 9.5 & 11.9 \\
\hline 29 & $\mathrm{C}$ & & 29.6 & 27.6 & 24.5 & 23.7 & 24.1 & 26.6 & 26.4 & 28.1 & 27.4 & 25.0 & 15.9 & 21.1 & 24.4 \\
\hline
\end{tabular}


Appendix B (continued)

\begin{tabular}{|c|c|c|c|c|c|c|c|c|c|c|c|c|c|c|c|}
\hline \multirow[b]{3}{*}{$n$-Alkane } & \multirow{3}{*}{$\begin{array}{l}\text { assigned } \\
\text { lipid pool }\end{array}$} & Transect & I & II & II & II & II & II & II & II & II & II & II & III & III \\
\hline & & Area & & $\mathrm{AO}$ & $\mathrm{AO}$ & YSC & YP & YP & YP & YP & MIZ & MIZ & & & YSC \\
\hline & & Station & 2830 & 2847 & 2848 & $55 / 95$ & $55 / 97$ & 2836 & 2835 & 2834 & 2863 & 2864 & 2865 & 2838 & $55 / 98$ \\
\hline 30 & & & 8.6 & 7.1 & 7.4 & 7.3 & 7.4 & 7.2 & 5.6 & 7.0 & 7.3 & 6.9 & 4.2 & 6.5 & 7.6 \\
\hline 31 & $\mathrm{C}$ & & 27.3 & 23.4 & 22.4 & 21.3 & 21.3 & 23.6 & 24.5 & 26.1 & 25.3 & 22.1 & 13.6 & 18.0 & 20.4 \\
\hline 32 & & & 5.2 & 3.7 & 4.6 & 5.7 & 4.2 & 4.0 & 3.3 & 4.2 & 4.2 & 4.2 & 3.4 & 3.8 & 4.7 \\
\hline Total ( $\mu \mathrm{g} / \mathrm{gTOC})$ & & & 330.7 & 242.0 & 265.2 & 273.5 & 261.4 & 242.2 & 222.6 & 262.0 & 267.0 & 241.6 & 166.7 & 227.7 & 292.4 \\
\hline$\Sigma$ assigned to $C \mu \mathrm{g} / \mathrm{gTO}$ & & & 106.8 & 96.3 & 88.7 & 85.4 & 88.2 & 93.6 & 92.2 & 99.9 & 98.4 & 88.8 & 55.8 & 76.0 & 89.8 \\
\hline$\%$ assigned to $\mathrm{C}$ & & & 32 & 40 & 33 & 31 & 34 & 39 & 41 & 38 & 37 & 37 & 33 & 33 & 31 \\
\hline CPI $(22-32)$ & & & 2.1 & 2.3 & 2.0 & 1.9 & 2.0 & 2.2 & 2.5 & 2.3 & 2.2 & 2.1 & 2.0 & 2.0 & 1.8 \\
\hline
\end{tabular}

\begin{tabular}{|c|c|c|c|c|c|c|c|c|c|c|c|c|c|c|c|}
\hline \multirow[b]{3}{*}{ n-Alkane } & \multirow[b]{2}{*}{ assigned } & \multicolumn{2}{|c|}{ Transect III } & & & & \multirow{2}{*}{$\frac{\text { III }}{\text { YSC }}$} & \multirow{2}{*}{$\begin{array}{l}\text { III } \\
\text { MIZ }\end{array}$} & \multirow{2}{*}{$\frac{\text { III }}{\text { MIZ }}$} & \multirow{2}{*}{$\frac{\text { III }}{\text { OW }}$} & \multirow{2}{*}{$\frac{\text { III }}{\text { OW }}$} & \multirow{2}{*}{$\frac{\text { III }}{\text { OW }}$} & \multirow{2}{*}{$\frac{\text { III }}{\text { OW }}$} & \multirow{2}{*}{$\frac{\text { III }}{\text { OW }}$} & \multirow{2}{*}{$\frac{\text { III }}{\text { OW }}$} \\
\hline & & Area & YSC & & & & & & & & & & & & \\
\hline & lipid pool & Station & 2837 & $55 / 93$ & $55 / 92$ & $57 / 160$ & $57 / 161$ & $55 / 77$ & $57 / 157$ & $55 / 158$ & $57 / 153$ & $57 / 123$ & $57 / 131$ & $57 / 138$ & $57 / 145$ \\
\hline 15 & & & 6.4 & 5.7 & 4.7 & 2.1 & 4.3 & 5.9 & 19.9 & 1.9 & 3.4 & 7.4 & 1.6 & n.d. & n.d. \\
\hline 16 & & & 11.8 & 13.6 & 9.9 & 6.5 & 10.2 & 12.8 & 23.5 & 7.9 & 8.3 & 13.4 & 9.8 & n.d. & n.d. \\
\hline 17 & & & 17.2 & 15.3 & 17.3 & 11.5 & 13.7 & 19.2 & 23.6 & 11.9 & 12.4 & 15.5 & 21.4 & n.d. & n.d. \\
\hline 18 & & & 16.0 & 18.0 & 16.7 & 15.0 & 17.6 & 16.7 & 23.4 & 15.4 & 14.3 & 16.1 & 28.6 & n.d. & n.d. \\
\hline 19 & & & 19.0 & 27.3 & 22.1 & 19.5 & 21.3 & 24.9 & 28.1 & 23.8 & 19.8 & 19.2 & 35.7 & n.d. & n.d. \\
\hline 20 & & & 16.2 & 18.0 & 17.8 & 17.2 & 18.8 & 16.7 & 22.3 & 18.0 & 15.0 & 15.3 & 34.2 & n.d. & n.d. \\
\hline 21 & & & 17.0 & 19.2 & 18.9 & 18.7 & 19.8 & 17.5 & 22.8 & 18.8 & 15.7 & 15.0 & 33.7 & n.d. & n.d. \\
\hline 22 & & & 15.4 & 18.8 & 17.9 & 17.2 & 18.1 & 15.6 & 21.2 & 20.3 & 15.3 & 13.8 & 31.3 & n.d. & n.d. \\
\hline 23 & & & 18.1 & 20.0 & 20.0 & 20.8 & 20.9 & 17.7 & 23.2 & 18.4 & 15.4 & 13.5 & 30.3 & n.d. & n.d. \\
\hline 24 & & & 13.6 & 14.9 & 15.0 & 15.2 & 15.8 & 13.8 & 18.2 & 14.5 & 12.2 & 11.1 & 25.6 & n.d. & n.d. \\
\hline 25 & $\mathrm{C}$ & & 17.3 & 18.9 & 19.0 & 20.0 & 20.0 & 16.7 & 21.7 & 15.7 & 14.6 & 11.5 & 25.4 & n.d. & n.d. \\
\hline 26 & & & 11.4 & 12.5 & 12.6 & 12.8 & 13.1 & 11.5 & 15.1 & 11.5 & 10.4 & 9.0 & 20.6 & n.d. & n.d. \\
\hline 27 & $\mathrm{C}$ & & 19.5 & 21.6 & 21.4 & 22.9 & 21.9 & 18.2 & 23.0 & 15.8 & 15.7 & 11.2 & 23.2 & n.d. & n.d. \\
\hline 28 & & & 10.0 & 11.1 & 11.0 & 11.0 & 11.4 & 10.3 & 13.0 & 9.8 & 9.1 & 8.4 & 17.2 & n.d. & n.d. \\
\hline 29 & $\mathrm{C}$ & & 20.4 & 22.5 & 22.3 & 23.4 & 22.2 & 18.8 & 23.5 & 15.8 & 16.9 & 11.1 & 21.1 & n.d. & n.d. \\
\hline 30 & & & 7.0 & 7.9 & 7.6 & 7.4 & 8.1 & 5.9 & 7.8 & 6.7 & 6.5 & 5.3 & 11.6 & n.d. & n.d. \\
\hline 31 & $\mathrm{C}$ & & 17.7 & 19.2 & 19.2 & 20.5 & 18.3 & 14.6 & 19.4 & 13.1 & 14.4 & 8.7 & 14.8 & n.d. & n.d. \\
\hline 32 & & & 4.1 & 4.9 & 4.4 & 4.3 & 4.4 & 4.0 & 5.2 & 5.2 & 4.0 & 3.1 & 6.4 & n.d. & n.d. \\
\hline Total $(\mu \mathrm{g} / \mathrm{g}$ & & & 258.1 & 289.4 & 277.8 & 266.0 & 279.9 & 260.8 & 354.9 & 244.5 & 223.4 & 208.6 & 392.5 & n.d. & n.d. \\
\hline$\Sigma$ assign & C) & & 74.9 & 82.2 & 81.9 & 86.8 & 82.4 & 68.3 & 87.6 & 60.4 & 61.6 & 42.5 & 84.5 & n.d. & n.d. \\
\hline$\%$ assign & & & 29 & 28 & 29 & 33 & 29 & 26 & 25 & 25 & 28 & 20 & 22 & n.d. & n.d. \\
\hline CPI $(22-3$ & & & 1.8 & 1.8 & 1.8 & 1.9 & 1.8 & 1.7 & 1.7 & 1.5 & 1.6 & 1.3 & 1.2 & n.d. & n.d. \\
\hline
\end{tabular}

Station locations are given in Fig. 1, for area abbreviations see text and Table 1. CPI=carbon preference index according to Bray and Evans (1961) calculated for the carbon atom number range from 22 to 32. Compounds of lipid pool C are attributed to a higher land plant origin. n.d. $=$ not determined. 


\section{Appendix C}

Concentrations ( $\mu \mathrm{g} / \mathrm{g}$ TOC) of $n$-alkanes and CPI in surface sediments from the eastern Fram Strait and on the Yermak Plateau

\begin{tabular}{|c|c|c|c|c|c|c|c|c|c|c|c|c|c|c|c|}
\hline \multirow[b]{3}{*}{ n-Alkanol } & \multirow[b]{2}{*}{ assigned } & \multicolumn{2}{|c|}{ Transect I } & \multirow{2}{*}{$\frac{\mathrm{I}}{\mathrm{AO}}$} & \multirow{2}{*}{$\begin{array}{l}\mathrm{I} \\
\mathrm{AO}\end{array}$} & \multirow{2}{*}{$\frac{\mathrm{I}+\mathrm{III}}{\mathrm{YSC}}$} & \multirow{2}{*}{$\begin{array}{l}\mathrm{I} \\
\mathrm{YP}\end{array}$} & \multirow{2}{*}{$\begin{array}{l}\mathrm{I} \\
\mathrm{YP}\end{array}$} & \multirow{2}{*}{$\begin{array}{l}\mathrm{I} \\
\mathrm{YP}\end{array}$} & \multirow{2}{*}{$\begin{array}{l}\mathrm{I} \\
\mathrm{YP}\end{array}$} & \multirow{2}{*}{$\begin{array}{l}\mathrm{I} \\
\mathrm{YP}\end{array}$} & \multirow[t]{2}{*}{ I } & \multirow[t]{2}{*}{ I } & \multirow[t]{2}{*}{ I } & \multirow{2}{*}{$\begin{array}{l}\mathrm{I} \\
\mathrm{MIZ}\end{array}$} \\
\hline & & Area & $\mathrm{AO}$ & & & & & & & & & & & & \\
\hline & lipid pool & Station & 2849 & 2851 & 2853 & 2854 & 2855 & 2856 & 2857 & 2858 & 2859 & 2860 & 2861 & 2832 & 2831 \\
\hline 16 & & & 12.0 & 15.3 & 16.8 & 28.3 & 16.1 & 17.5 & 15.5 & 15.1 & 15.3 & 11.6 & 17.2 & 18.1 & 17.4 \\
\hline 18 & & & 38.8 & 31.3 & 38.1 & 52.4 & 23.5 & 30.4 & 27.6 & 22.7 & 29.4 & 24.2 & 26.7 & 32.5 & 39.1 \\
\hline 22 & $\mathrm{C}$ & & 40.1 & 32.6 & 32.4 & 51.2 & 29.7 & 33.3 & 41.8 & 32.6 & 38.1 & 30.8 & 36.2 & 37.2 & 36.8 \\
\hline 24 & $\mathrm{C}$ & & 31.2 & 24.7 & 26.2 & 97.9 & 21.4 & 27.3 & 33.0 & 24.0 & 30.3 & 22.7 & 28.0 & 26.7 & 29.2 \\
\hline 26 & $\mathrm{C}$ & & 66.8 & 37.5 & 42.0 & 50.3 & 34.3 & 38.5 & 67.8 & 39.9 & 48.1 & 33.6 & 50.7 & 46.6 & 36.2 \\
\hline 28 & $\mathrm{C}$ & & 36.9 & 28.2 & 28.8 & 33.2 & 21.6 & 25.6 & 41.4 & 25.2 & 31.8 & 21.1 & 32.5 & 26.2 & 31.2 \\
\hline \multicolumn{2}{|c|}{ Total ( $\mu \mathrm{g} / \mathrm{gTOC})$} & & 225.8 & 169.6 & 184.3 & 313.3 & 146.6 & 172.6 & 227.1 & 159.5 & 193.0 & 144.0 & 191.3 & 187.3 & 189.9 \\
\hline \multicolumn{2}{|c|}{$\Sigma$ assigned to $\mathrm{C}(\mu \mathrm{g} / \mathrm{gTOC})$} & & 175.0 & 123.0 & 129.4 & 232.6 & 107.0 & 124.7 & 184.0 & 121.7 & 148.3 & 108.2 & 147.4 & 136.7 & 133.4 \\
\hline \multicolumn{2}{|c|}{$\%$ assigned to $\mathrm{C}$} & & 78 & 73 & 70 & 74 & 73 & 72 & 81 & 76 & 77 & 75 & 77 & 73 & 70 \\
\hline \multirow[b]{3}{*}{ n-Alkanol } & & \multicolumn{2}{|c|}{ Transect I } & II & II & II & II & II & II & II & II & II & II & III & III \\
\hline & assigned & Area & & $\mathrm{AO}$ & $\mathrm{AO}$ & YSC & YP & YP & YP & YP & MIZ & MIZ & & & YSC \\
\hline & lipid pool & Station & 2830 & 2847 & 2848 & $55 / 95$ & $55 / 97$ & 2836 & 2835 & 2834 & 2863 & 2864 & 2865 & 2838 & $55 / 98$ \\
\hline 16 & & & 19.6 & 14.0 & 22.7 & 260.5 & 20.4 & 18.9 & 15.2 & 14.3 & 15.5 & 20.1 & 11.9 & 17.5 & 21.3 \\
\hline 18 & & & 46.0 & 38.8 & 31.3 & 33.9 & 24.6 & 35.7 & 33.2 & 30.7 & 18.5 & 59.5 & 21.3 & 24.4 & 37.0 \\
\hline 22 & $\mathrm{C}$ & & 44.4 & 31.8 & 41.3 & 35.9 & 40.1 & 38.9 & 40.1 & 29.0 & 37.9 & 41.4 & 24.9 & 30.5 & 35.0 \\
\hline 24 & $\mathrm{C}$ & & 42.4 & 26.5 & 29.0 & 27.4 & 29.9 & 29.2 & 29.2 & 24.3 & 29.5 & 29.6 & 17.1 & 20.9 & 25.0 \\
\hline 26 & $\mathrm{C}$ & & 67.2 & 46.8 & 45.7 & 43.4 & 46.8 & 48.3 & 54.3 & 49.1 & 54.1 & 45.1 & 26.7 & 34.7 & 38.3 \\
\hline 28 & $\mathrm{C}$ & & 48.5 & 32.2 & 29.3 & 29.9 & 29.5 & 30.1 & 35.0 & 33.3 & 35.0 & 29.5 & 20.0 & 22.7 & 25.8 \\
\hline \multicolumn{2}{|c|}{ Total ( $\mu \mathrm{g} / \mathrm{gTOC})$} & & 268.1 & 190.1 & 199.3 & 431.0 & 191.3 & 201.1 & 207.0 & 180.7 & 190.5 & 225.2 & 121.9 & 150.7 & 182.4 \\
\hline \multicolumn{2}{|c|}{$\Sigma$ assigned to $\mathrm{C}(\mu \mathrm{g} / \mathrm{gTOC})$} & & 202.5 & 137.3 & 145.3 & 136.6 & 146.3 & 146.5 & 158.6 & 135.7 & 156.5 & 145.6 & 88.7 & 108.8 & 124.1 \\
\hline \multicolumn{2}{|c|}{$\%$ assigned to $\mathrm{C}$} & & 76 & 72 & 73 & 32 & 76 & 73 & 77 & 75 & 82 & 65 & 73 & 72 & 68 \\
\hline
\end{tabular}

\begin{tabular}{|c|c|c|c|c|c|c|c|c|c|c|c|c|c|c|c|}
\hline \multirow[b]{3}{*}{$n$-Alkanol } & \multirow[b]{2}{*}{ assigned } & \multicolumn{2}{|c|}{ Transect III } & & \multirow{2}{*}{$\begin{array}{l}\text { III } \\
\text { YSC }\end{array}$} & & & & \multirow{2}{*}{$\begin{array}{l}\text { III } \\
\text { MIZ }\end{array}$} & \multirow{2}{*}{$\begin{array}{l}\text { III } \\
\text { OW }\end{array}$} & \multirow{2}{*}{$\begin{array}{l}\text { III } \\
\text { OW }\end{array}$} & \multirow{2}{*}{$\begin{array}{l}\text { III } \\
\text { OW }\end{array}$} & \multirow{2}{*}{$\begin{array}{l}\text { III } \\
\text { OW }\end{array}$} & \multirow{2}{*}{$\begin{array}{l}\text { III } \\
\text { OW }\end{array}$} & \multirow{2}{*}{$\begin{array}{l}\text { III } \\
\text { OW }\end{array}$} \\
\hline & & Area & YSC & & & & & & & & & & & & \\
\hline & lipid pool & Station & 2837 & $55 / 93$ & $55 / 92$ & $57 / 160$ & $57 / 161$ & $55 / 77$ & $57 / 157$ & $55 / 158$ & $57 / 153$ & $57 / 123$ & $57 / 131$ & $57 / 138$ & $57 / 145$ \\
\hline 16 & & & 18.8 & 136.8 & 25.9 & 31.8 & 22.6 & 27.1 & 45.6 & 17.6 & 17.7 & 30.4 & 39.5 & 25.1 & 15.1 \\
\hline 18 & & & 18.0 & 26.3 & 23.3 & 27.2 & 26.2 & 37.3 & 39.8 & 31.2 & 17.9 & 22.2 & 34.7 & 33.3 & 22.4 \\
\hline 22 & $\mathrm{C}$ & & 30.9 & 38.8 & 37.3 & 41.6 & 34.5 & 45.3 & 34.4 & 23.7 & 24.8 & 15.0 & 19.0 & 9.7 & 16.9 \\
\hline 24 & $\mathrm{C}$ & & 23.6 & 26.6 & 25.8 & 29.8 & 22.7 & 31.5 & 24.8 & 16.7 & 17.6 & 11.2 & 12.2 & 6.5 & 12.0 \\
\hline 26 & $\mathrm{C}$ & & 31.8 & 36.7 & 37.2 & 39.8 & 25.8 & 44.9 & 30.7 & 18.7 & 20.0 & 11.5 & 16.4 & 6.2 & 16.1 \\
\hline 28 & $\mathrm{C}$ & & 19.0 & 21.2 & 22.2 & 19.5 & 21.1 & 24.4 & 19.8 & 12.1 & 8.9 & 6.3 & 9.4 & 4.2 & 10.9 \\
\hline Total $(\mu \mathrm{g} / \mathrm{g}$ & & & 142.1 & 286.4 & 171.7 & 189.7 & 152.9 & 210.5 & 195.1 & 120.0 & 106.9 & 96.6 & 131.2 & 85.0 & 93.4 \\
\hline$\Sigma$ assigne & ( $\mu \mathrm{g} / \mathrm{gTOC})$ & & 105.3 & 123.3 & 122.5 & 130.7 & 104.1 & 146.1 & 109.7 & 71.2 & 71.3 & 44.0 & 57.0 & 26.6 & 55.9 \\
\hline$\%$ assigne & & & 74 & 43 & 71 & 69 & 68 & 69 & 56 & 59 & 67 & 46 & 43 & 31 & 60 \\
\hline
\end{tabular}

Station locations are given in Fig. 1, for area abbreviations see Table 1 and text. Compounds of lipid pool C are attributed to a higher land plant origin. 


\section{References}

Albers, C.S., Kattner, G., Hagen, W., 1996. The compositions of wax esters, triacylglycerols and phospholipids in Arctic and Antarctic copepods: evidence of energetic adaptions. Mar. Chem. 55, 347-358.

Alldredge, A.L., Jackson, G.A., 1995. Aggregation in marine systems. Deep Sea Res. I 42, 1-7.

Andreassen, I., Nöthig, E.M., Wassmann, P., 1996. Vertical particle flux on the shelf off northern Spitsbergen. Mar. Ecol. Prog. Ser. $137,215-218$.

ARCSS Workshop Steering Committee, 1990. Arctic System Science: Ocean-Atmosphere-Ice Interactions. Lake Arrowhead Workshop Reports JOI, Washington, DC.

Belicka, L.L., Macdonald, R.W., Harvey, H.R., 2002. Sources and transport of organic carbon to shelf, slope, and basin surface sediments of the Arctic Ocean. Deep Sea Res. I 49, $1463-1483$.

Birgel, D., Stein, R.W., 2003. Northern Fram Strait und Yermak Plateau: Distribution, sources, variability and burial of organic carbon. In: Stein, R., Macdonald, R.W. (Eds.), Organic Carbon Cycle of the Arctic Ocean. Springer Verlag, Berlin, pp. 279-294.

Bligh, E.G., Dyer, W.J., 1959. A rapid method of total lipid extraction and purification. Can. J. Biochem. Physiol. 37, 911-917.

Boon, J.J., Rijpstra, W.I.C., de Lange, F., de Leeuw, J.W., Yoshioka, M., Shimizu, Y., 1979. Black sea sterol-a molecular fossil for dinoflagellate blooms. Nature 277, 125-127.

Boschker, H.T.S., Middelburg, J.J., 2002. Stable isotopes in microbial ecology. FEMS Microbiol. Ecol. 40, 85-95.

Budge, S.M., Parrish, C.C., 1998. Lipid biogeochemistry of plankton, settling matter and sediments in Trinity Bay, Newfoundland: II. Fatty Acids. Org. Geochem. 29, 1547-1559.

Budge, S.M., Parrish, C.C., McKenzie, C.H., 2001. Fatty acid compositions of phytoplankton, settling particulate matter and sediments at a sheltered bivalve aquaculture site. Mar. Chem. 76, $285-303$.

Bray, E.E., Evans, E.D., 1961. Distribution of n-paraffins as a clue to recognition of source beds. Geochim. Cosmochim. Acta 22, $2-15$.

Claustre, H., Marty, J., Cassiani, L., Dagaut, J., 1988-1989. Fatty acid dynamics in phytoplankton and microzooplankton communities during a spring bloom in the coastal Ligurian Sea: ecological implications. Mar. Microb. Food Webs 3, $51-56$.

Collister, J.W., Rieley, G., Stern, B., Eglinton, G., Fry, B., 1994. Compound-specific $\delta^{13} \mathrm{C}$ analyses of leaf lipids from plants with differing carbon dioxide metabolisms. Org. Geochem. 21, 619-627.

Cooper, W.J., Blumer, M., 1968. Linear, iso and anteiso fatty acids in Recent sediments of the North Atlantic. Deep Sea Res. 15, $535-540$.

Dethleff, D., Rachold, V., Tintelnot, T., Antonow, M., 2000. Seaice transport of riverine particles from the Laptev Sea to Fram Strait based on clay mineral studies. Int. J. Earth Sci. 89, 496-502.
Eglinton, G., Hamilton, R.J., 1963. The distribution of n-alkanes. In: Swain, T. (Ed.), Chemical Plant Taxonomy. Academic Press, London, pp. 187-217.

Eglinton, G., Hamilton, R.J., 1967. Leaf epicuticular waxes. Science $156,1322-1335$.

Eglinton, G., Hamilton, R.J., Raphael, R.A., Gonzalez, A.G., 1962. Hydrocarbon constituents of the wax coatings of plant leaves: a taxonomic survey. Nature 193, 739-742.

Eglinton, G., Hunnemann, D.H., Douraghi-Zadeh, K., 1968. Gas-chromatographic-mass spectrometric studies of long chain hydroxy acids: II. The hydroxy acids and fatty acids of a 5000 year old lacustrine sediment. Tetrahedron 24, 5929-5941.

Eicken, H., Kolatschek, J., Freitag, J., Lindemann, F., Kassens, H., Dmitrenko, I., 2000. A key source area and constraints on entrainment for basin-scale sediment transport by Arctic sea ice. Geophys. Res. Lett. 27, 1919-1922.

English, T.S., 1961. Some biological oceanographic observations in the central north Polar Sea. Drift Station Alpha, 1957-1958. Arct. Inst. North Am. Res. Pap. 13, 1-80.

Fahl, K., Stein, R., 1999. Biomarkers as organic-carbon-source and environmental indicators in the Late Quaternary Arctic Ocean: problems and perspectives. Mar. Chem. 63, 293-309.

Fahrbach, E., Meincke, J., Østerhus, S., Rohardt, G., Schauer, U., Tverberg, V., Verduin, J., 2001. Direct measurements of volume transports through Fram Strait. Pol. Res. 20, 217-224.

Falk-Petersen, S., Sargent, J.R., Henderson, J., Hegseth, E.N., Hop, H., Okolodkov, Y.B., 1998. Lipids and Fatty Acids in ice algae and phytoplankton from the Marginal Ice Zone in the Barents Sea. Pol. Biol. 20, 41-47.

Falk-Petersen, S., Hop, H., Budgell, W.P., Hegseth, E.N., Korsnes, R., Løyning, T.B., Ørbæk, J.B., Kawamura, T., Shirasawa, K., 2000. Physical and ecological processes in the marginal ice zone of the northern Barents Sea during the summer melt period. J. Mar. Syst. 27, 131-159.

Farrimond, P., Eglinton, G., Poynter, J.G., 1990. A molecular and stratigraphic study of Peru margin sediments, HOLE 686B, LEG 1121. Proc. Ocean Drill. Program Sci. Results 112, $539-546$.

Fernandes, M.B., Sicre, M.-A., 2000. The importance of terrestrial organic carbon inputs on Kara Sea shelves as revealed by $n$-alkanes, OC and $\delta^{13} \mathrm{C}$ values. Org. Geochem. 31, $363-374$.

Ficken, K.J., Barber, K.E., Eglinton, G., 1998. Lipid biomarker, $\delta^{13} \mathrm{C}$ and plant macrofossil stratigraphy of a Scottish montane peat bog over the last two millenia. Org. Geochem. 28, $217-237$.

Folch, J., Lees, M., Sloane-Stanley, G.H., 1957. A simple method for the isolation and purification of total lipids from animal tissues. J. Biol. Chem. 226, 497-509.

Freeman, K., Pancost, R.D., Filley, T.R., Wakeham, S.G., 1995. Environmental and physiological controls on the $\delta^{13} \mathrm{C}$ of phytoplankton biomarkers: sterols and alkenones from marine waters and sediments. In: Grimalt, J.O., Dorronsoro, C. (Eds.), Organic Geochemistry, Developments and Applications to Energy, Climate, Environment and Human History. AIGOA, Donastia-San Sebastian, pp. 14-16. 
Fütterer, D.K. (Ed.), 1992. ARCTIC, 91: The Expedition ARK VIII/3 of RV "Polarstern" in 1991. Ber. Polarforsch., vol. 107 , pp. $1-267$.

Fütterer, D.K. (Ed.), 1994. The expedition ARCTIC, 93, LEG ARK-IX/4 of RV "Polarstern" 1993. Ber. Polarforsch., vol. 149 , pp. $1-244$.

Gagosian, R.B., Peltzer, E.T., 1985. The importance of atmospheric input of terrestrial organic matter to deep sea sediments. Org. Geochem. 10, 661-669.

Gascard, J.-C., Kergomard, C., Jeannin, P.-F., Fily, M., 1988. Diagnostic study of the Fram Strait Marginal Ice Zone during summer from 1983 and 1984 Marginal Ice Zone Experiment lagrangian observations. J. Geophys. Res. 93, 3613-3641.

Gillan, F.T., Sandstrom, M.W., 1985. Microbial lipids from a nearshore sediment from Bowling Green Bay, North Queensland: the fatty acid composition of intact lipid fractions. Org. Geochem. 8, 321-328.

Goñi, M.A., Yunker, M.B., Macdonald, R.W., Eglinton, T.I., 2000. Distribution and sources of organic biomarkers in Arctic sediments from the Mackenzie River and Beaufort Shelf. Mar. Chem. 71, 23-51

Gosselin, M., Levasseur, M., Wheeler, P.A., Horner, R.A., Booth, B.C., 1997. New measurements of phytoplankton and ice algal production in the Arctic Ocean. Deep Sea Res. II. 44, 1623-1644.

Graeve, M., Kattner, G., Piepenburg, D., 1997. Lipids in Arctic benthos: does the fatty acid and alcohol composition reflect feeding and trophic interactions. Pol. Biol. 18, 53-61.

Gundelwein, A., 1998. Eigenschaften und Umsetzung organischer Substanz in nordsibirischen Permafrostböden. PhD thesis. Hamburger Bodenkundliche Arb. 39, Hamburg, pp. 1-192.

Hebbeln, D., Berner, H., 1993. Surface sediment distribution in the Fram Strait. Deep Sea Res. I 40, 1731-1745.

Hebbeln, D., 2000. Flux of ice-rafted detritus from sea ice in the Fram Strait. Deep Sea Res. II 47, 1773-1790.

Henderson, R.J., Hegseth, E.N., Park, M.T., 1998. Seasonal variation in lipid and fatty acid composition of ice algae from the Barents Sea. Pol. Biol. 20, 48-55.

Hirche, H.-J., Baumann, M.E.M., Kattner, G., Gradinger, R., 1991. Plankton distribution and the impact of copepod grazing on primary production in Fram Strait, Greenland Sea. J. Mar. Syst. 2, 477-494.

Hobson, K.A., Welch, H.E., 1992. Determination of trophic relationships within a high Arctic marine food web using $\delta^{13} \mathrm{C}$ and $\delta^{15} \mathrm{~N}$ analysis. Mar. Ecol. Prog. Ser. 84, 9-18.

Huang, Y., Lockheart, M.J., Logan, G.A., Eglinton, G., 1996. Isotope and molecular evidence for the diverse origins of carboxylic acids in leaf fossils and sediments from the Miocene Lake Clarkia deposit, Idaho, U.S.A. Org. Geochem. 24, 289-299.

Hunkins, K., 1986. Anomalous diurnal tidal currents on the Yermak Plateau. J. Mar. Res. 44, 51-69.

IUPAC-IUB Commission on Biochemical Nomenclature (CBN) 1976. Nomenclature of Lipids, Recommendations. http://www. chem.qmul.ac.uk/iupac/lipid/.

Jokat, W. (Ed.), 2000. The Expedition ARKTIS-XV/2 of "Polarstern" in 1999. Ber. Polarforsch., vol. 368, pp. 1-128.
Kaneda, T., 1991. Iso- and anteiso-fatty acids in bacteria: biosynthesis, function, and taxonomic significance. Microbiol. Rev. 55, $288-302$.

Kattner, G., Hagen, W., 1995. Polar herbivorous copepods-different pathways in lipid biosynthesis. ICES J. Mar. Sci. 52, $329-335$.

Kattner, G., Hirche, H.-J., Krause, M., 1989. Spatial variability in lipid composition of calanoid copepods from Fram Strait, the Arctic. Mar. Biol. 102, 473-480.

Kierdorf, C., 2001. Organischer Kohlenstoff und Biomarker in Oberflächensedimenten vom Ostgrönländischen Kontinentalhang. Diploma Thesis. Geologisches Institut der Universität Köln/Alfred Wegener Institute for Polar and Marine Research, Bremerhaven. Unpublished.

Kirst, G.O., Wiencke, C., 1995. Ecophysiology of polar algae. J. Phycol. 31, 181-199.

Krause, G., Schauer, U. (Eds.), 2001. The Expeditions ARKTIS $\mathrm{XVI} / 1$ and ARKTIS XVI/2 of the Research Vessel "Polarstern" in 2000. Ber. Polarforsch., vol. 389, pp. 1-108.

Kunst, L., Samuels, A.L., 2003. Biosynthesis and secretion of plant cuticular waxes. Prog. Lipid Res. 42, 51-80.

Leo, R.F., Parker, P.L., 1966. Branched-chain fatty acids in sedments. Science $152,649-650$.

Macdonald, R.W., Solomon, S.M., Cranston, R.E., Welch, H.E., Yunker, M.B., Gobeil, C., 1998. A sediment and organic carbon budget for the Canadian Beaufort Shelf. Mar. Geol. $144,255-273$.

Manley, T.O., 1995. Branching of Atlantic Water within the Greenland-Spitsbergen passage: an estimate of recirculation. J. Geophys. Res. 100, 20627-20634.

Mayzaud, P., Chanut, J.P., Ackman, R.G., 1989. Seasonal changes of the biochemical composition of marine particulate matter with special reference to fatty acids and sterols. Mar. Ecol. Prog. Ser. 56, 189-204.

Mueller-Lupp, T., Bauch, H.A., Erlenkeuser, H., Hefter, J., Kassens, H., Thiede, J., 2000. Changes in the deposition of terrestrial organic matter on the Laptev Sea shelf during the Holocene: evidence from stable carbon isotopes. Int. J. Earth Sci. 89, 563-568.

Muench, R.D., McPhee, M.G., Paulson, C.A., Morison, J.H., 1992. Winter oceanographic conditions in the Fram Strait-Yermak Plateau region. J. Geophys. Res. 97, 3469-3483.

NAD Science Committee, 1992. The Arctic Ocean record: key to global change (initial science plan of the Nansen Arctic Drilling Program). Polarforschung 161, 102.

Naidu, A.S., Cooper, L.W., Finney, B.P., Macdonald, R.W., Alexander, R., Smelitov, I.P., 2000. Organic carbon isotope ratios $\left(\delta^{13} \mathrm{C}\right)$ of Arctic Amerasian Continental shelf sediments. Int. J. Earth Sci. 89, 522-532.

Naraoka, H., Ishiwatari, R., 2000. Molecular and isotopic abundances of long-chain $n$-fatty acids in open marine sediments of the western North Pacific. Chem. Geol. $165,23-36$.

Notholt, H., 1998. The implicaton of the "NorthEastWater"-Polynya on the sedimentation by NE-Greenland and Late Quaternary Paleooceanic investigations, $\mathrm{PhD}$ thesis. Ber. Polarforsch., vol. 275, pp. 1-183. Bremerhaven. 
Olli, K., Wexels Riser, C., Wassmann, P., Rat'kova, T., Arashkevich, E., Pasternak, A., 2002. Seasonal variation in vertical flux of biogenic matter in the marginal ice zone and the central Barents Sea. J. Mar. Syst. 38, 189-204.

Owrid, G., Socal, G., Civitarese, G., Luchetta, A., Wiktor, J., Nöthig, E.-M., Andreassen, I., Schauer, U., Strass, V., 2000. Spatial variability of phytoplankton, nutrients and new production estimates in the waters around Svalbard. Pol. Res. 19, 155-171.

Pancost, R.D., Freeman, K.H., Wakeham, S.G., Robertson, C.Y., 1997. Controls on carbon isotope fractionation by diatoms in the Peru upwelling region. Geochim. Cosmochim. Acta 61, 4983-4991.

Parkes, R.J., Taylor, J., 1983. The relationship between fatty acid distributions and bacterial respiratory types in contemporary marine sediments. Estuar. Coast. Shelf Sci. 16, 173-189.

Parrish, C.C., Abrajano, T.A., Budge, S.M., Helleur, R.J., Hudson, E.D., Pulchan, K., Ramos, C., 2000. Lipids and phenolic biomarkers in marine ecosystems: Analysis and applications. In: Wangersky, P. (Ed.), The Handbook of Environmental Chemistry. Marine Chemistry, vol. 5, Part D. Springer Verlag, Berlin, pp. 193-223.

Peinert, R., Anita, A., Bauerfeind, E., von Bodungen, B., Haupt, O., Krumbholz, M., Peeken, I., Ramseier, R.O., Voss, M., Zeitzschel, B., 2001. Particle flux variability in the Polar and Atlantic biogeochemical provinces of the Nordic Seas. In: Schäfer, P., Ritzrau, W., Schlüter, M., Thiede, J. (Eds.), The Northern North Atlantic. Springer, Berlin, pp. 53-68.

Perry, G.J., Volkman, J., Johns, R.B., 1979. Fatty Acids of bacterial origin in contemporary marine sediments. Geochim. Cosmochim. Acta 43, 1715-1725.

Peterson, B.J., 1999. Stable isotopes as tracers of organic matter input and transfer in benthic food webs: a review. Acta Oecol. 20, 479-487.

Pfeiffer, E.M., Janssen, H., 1993. Characterization of organic carbon, using the $\delta^{13} \mathrm{C}$-value of a permafrost site in KolymaIndirka lowland, Northeast Siberia. In: Kimble, J.M., Ahrens, R.J. (Eds.), Proc. Meeting on the Classification, Correlation and Management of Permafrost Affected Soils. USDA, Soil Conservation Service, Lincoln, Nebraska, pp. 90-98.

Pfirman, S.L., Kögeler, J.W., Rigor, I., 1997. Potential for rapid transport of contaminants from the Kara Sea. Sci. Total Environ. 202, $111-122$.

Pond, D.W., Bell, M.V., Harris, R.P., Sargent, J.R., 1998. Microplanktonic polyunsaturated fatty acid markers: a mesocosm trial. Estuar. Coast. Shelf Sci. 46, 61-67.

Prahl, F.G., Ertel, J.R., Goñi, M.A., Sparrow, M.A., Eversmeyer, B., 1994. Terrestrial organic-carbon contributions to sediments on the Washington margin. Geochim. Cosmochim. Acta 58, 3035-3048.

Ramos, C.S., Parrish, C.C., Quibuyen, T.A.O., Abrajano, T.A., 2003. Molecular and carbon isotopic variations in lipids in rapidly settling particles during a spring phytoplankton bloom. Org. Geochem. 34, 195-207.

Ramseier, R.O., Garrity, C., Bauerfeind, E., Peinert, R., 1999. Seaice impact on long-term particle flux in the Greenland Sea's Is Odden-Nordbukta region, 1985-1996. J. Geophys. Res. 104 (C3), 5329-5343.
Ramseier, R.O., Garrity, C., Martin, T., 2001. An overview of seaice conditions in the Greenland Sea and the relationship of oceanic sedimentation to the ice regime. In: Schäfer, P., Ritzrau, W., Schlüter, M., Thiede, J. (Eds.), The Northern North Atlantic. Springer, Berlin, pp. 19-38.

Rat'kova, T.N., Wassmann, P., 2002. Seasonal variation and spatial distribution of phyto- and protozooplankton in the central Barents Sea. J. Mar. Syst. 38, 47-75.

Rieley, G., Collier, R.J., Jones, D.M., Eglinton, G., Eakin, P.A., Fallick, A.E., 1991. Sources of sedimentary lipids deduced from stable isotope analyses of individual compounds. Nature 352 , $425-427$.

Rudels, B., Meyer, R., Fahrbach, E., Ivanov, V.V., Østerhus, S., Quadfasel, D., Schauer, U., Tverberg, V., Woodgate, R.A., 2000. Water mass distribution in Fram Strait and over the Yermak Plateau in summer 1997. Ann. Geophys. 18, 687-705.

Russel, N.J., Nichols, D.S., 1999. Polyunsaturated fatty acids in marine bacteria-a dogma rewritten. Microbiology 145, $767-779$.

Rutgers van der Loeff, M.M., Meyer, R., Rudels, B., Rachor, E., 2002. Resuspension and particle transport in the benthic nepheloid layer in and near Fram Strait in relation to faunal abundance and ${ }^{234} \mathrm{Th}$ depletion. Deep Sea Res. I 49, 1941-1958.

Saloranta, T.M., Svendsen, H., 2001. Across the Arctic front west of Spitsbergen: high resolution CTD sections from 1998-2000. Pol. Res. 20, 177-184.

Sargent, J.R., Henderson, R.J., 1986. Lipids. In: Corner, E.D.S., O'Hara, S. (Eds.), Biological Chemistry of Marine Copepods. University Press, Oxford, pp. 59-108.

Schefuß, E., Ratmeyer, V., Stuut, J.-B.W., Jansen, J.H.F., Sinninghe Damsté, J.S., 2003. Carbon isotope analysis of $n$-alkanes in dust from the lower atmosphere over the central eastern Atlantic. Geochim. Cosmochim. Acta 67, 1757-1767.

Schewe, I., Soltwedel, T., 2003. Benthic response to ice-edge induced particle flux in the Arctic Ocean. Pol. Biol. 26, $610-620$.

Schlichtholz, P., Houssais, M.-N., 1999a. An inverse modelling study in Fram Strait: Part I. Dynamics and circulation. Deep Sea Res. II 46, 1083-1135.

Schlichtholz, P., Houssais, M.-N., 1999b. An inverse modelling study in Fram Strait: Part II. Water mass distribution and transports. Deep Sea Res. II 46, 1137-1168.

Schlitzer, R., 2002. Ocean Data View. WWW Page, http:// www.awi-bremerhaven.de/GEO/ODV.

Schoster, F., Behrends, M., Müller, C., Stein, R., Wahsner, M., 2000. Modern river discharge and pathways of supplied material in the Eurasian Arctic Ocean: evidence from mineral assemblages and major and minor element distribution. Int. J. Earth Sci. 89, 486-495.

Schubert, C.J., 1995. Organic carbon in late Quaternary Arctic Ocean sediments: Terrigenous supply and marine productivity. $\mathrm{PhD}$ thesis, Ber. Polarforsch., vol. 177. Bremerhaven, pp. 1-178.

Schubert, C.J., Calvert, S.E., 2001. Nitrogen and carbon isotopic composition of marine and terrestrial organic matter in the Arctic Ocean sediments: implications for nutrient utilization and organic matter composition. Deep Sea Res. I 48, 789-810. 
Schubert, C.J., Stein, R., 1997. Lipid distribution in surface sediments from the eastern central Arctic Ocean. Mar. Geol. 138, $11-25$.

Scott, C.L., Falk-Petersen, S., Gulliksen, B., Lønne, O.-J., Sargent, J.R., 2001. Lipid indicators of the diet of the sympagic amphipod Gammarus wilkit zkii in the Marginal Ice Zone and in open waters of Svalbard (Arctic). Pol. Biol. 24, 572-576.

Scott, C.L., Kwasniewski, S., Falk-Petersen, S., Sargent, J.R., 2002. Lipids and fatty acids in the copepod Jaschnovia brevis (Jaschnov) and in particulates from Arctic waters. Pol. Biol. 25, 65-71.

Shi, W., Sun, M.-Y., Molina, M., Hodson, R.E., 2001. Variability in the distribution of lipid biomarkers and their molecular isotopic composition in Altamaha estuarine sediments: implications for the relative contribution of organic matter from various sources. Org. Geochem. 32, 453-467.

Sicre, M.A., Paillasseur, J.L., Marty, J.C., Saliot, A., 1988. Characterization of seawater samples using chemometric methods applied to biomarker fatty acids. Org. Geochem. 3, 281-288.

Simoneit, B.R.T., 1978. The organic chemistry of marine sediments. In: Riley, J.P., Chester, R. (Eds.), Chemical Oceanography, vol. 7. Academic Press, London, pp. 233-311.

Smith, W.O., Baumann, M.E.M., Wilson, D.L., Aletsee, L., 1987. Phytoplankton biomass and productivity in the marginal ice zone of the Fram Strait during summer 1984. J. Geophy. Res. $92,6777-6786$

Soltwedel, T., Mokievsky, V., Schewe, I., 2000. Benthic activity and biomass on the Yermak Plateau and in adjacent deep-sea regions northwest of Svalbard. Deep Sea Res. II 47, $1761-1785$.

Stein, R., Fahl, K. (Eds.), 1997. Scientific cruise report of the Arctic Expedition of ARK-XIII/2 of RV "Polarstern" in 1997. Ber. Polarforsch., vol. 255, pp. 1-235.
Stein, R., Fahl, K., 2000. Holocene accumulation of organic carbon at the Laptev Sea Continental margin (Arctic Ocean): sources, pathways, and sinks. Geo Mar. Lett. 20, 27-36.

Stein, R., Grobe, H., Wahsner, M., 1994. Organic carbon, carbonate, and clay mineral distributions in eastern central Arctic ocean surface sediments. Mar. Geol. 119, 269-285.

Subba Rao, D.V., Platt, T., 1984. Primary production of Arctic waters. Pol. Biol. 3, 191-201.

Tanoue, E., Handa, N., 1980. Vertical transport of organic materials in the North Pacific as determined by sediment trap experiment. J. Oceanogr. Soc. Japan 36, 231-245.

van Dongen, B.E., Schouten, S., Sinninghe Damsté, J.S., 2002. Carbon isotope variability in monosaccharides and lipids of aquatic algae and terrestrial plants. Mar. Ecol. Prog. Ser. 232, $83-92$.

Viso, A.-C., Marty, J.-C., 1993. Fatty acids from 28 marine microalgae. Phytochemistry $34,1521-1533$.

Volkman, J.K., Jeffrey, S.W., Nichols, P.D., Rogers, G.I., Garland, C.D., 1989. Fatty acid and lipid composition of 10 species of microalgae used in mariculture. J. Exp. Mar. Biol. Ecol. 128, $219-240$

Volkman, J.K., Barrett, S.M., Blackburn, S.I., Mansour, M.P., Sikes, E.L., Gelin, F., 1998. Microalgal biomarkers: a review of recent research developments. Org. Geochem. 29, $1163-1179$.

Wassmann, P., 2002. Seasonal C-cycling variability in the open and ice-covered waters of the Barents Sea: an introduction. J. Mar. Syst. 38, 1-7.

Wheeler, P.A., Gosselin, M., Sherr, E., Thibault, D., Kirchman, D.L., Benner, R., Whitledge, T.E., 1996. Active cycling of organic carbon in the central Arctic Ocean. Nature 380, 697-699.

Zhukova, N.V., Aizdaicher, N.A., 1995. Fatty acid composition of 15 species of marine microalgae. Phytochemistry $39,351-356$. 